\title{
Characterization of Leak Pathways in the Below Grade Ducts of the Brookhaven Graphite Research Reactor Using Perfluorocarbon Tracers
}

Environmental Sciences Department

Brookhaven National Laboratory

Brookhaven Science Associates

Upton, Long Island, New York 11973

Under Contract No. DE-AC02-98CH10886 with the

UNITED STATES DEPARTMENT OF ENERGY 


\section{DISCLAIMER}

This report was prepared as an account of work sponsored by an agency of the United States Government. Neither the United State Government nor any agency thereof, nor any of their employees, not any of their contractors, subcontractors, or their employees, makes any warranty, express or implied, or assumes any legal liability or responsibility for the accuracy, completeness, or usefulness of any information, apparatus, product, or process disclosed, or represents that its use would not infringe privately owned rights. Reference herein to any specific commercial product, process, or service by trade name, trademark, manufacturer, or otherwise, does not necessarily constitute or imply its endorsement, recommendation, or favoring by the United States Government or any agency, contractor, or subcontractor thereof. The views and opinions of authors expressed herein do not necessarily state or reflect those of the United States Government or any agency, contractor or subcontractor thereof. 


\section{Characterization of Leak Pathways in the Below Grade Ducts of the Brookhaven Graphite Research Reactor Using Perfluorocarbon Tracers}

John Heiser, Terrence Sullivan, Paul Kalb,

Lawrence Milian, Richard Wilke, Clyde Newson, and Manny Lilimpakis

Brookhaven National Laboratory

Upton, New York

April 2001

Brookhaven National Laboratory

Brookhaven Science Associates

Upton, Long Island New York 11973

Under Contract No. DE-AC02-98CH10886 with the

UNITED STATES DEPARTMENT OF ENERGY 

TABLE OF CONTENTS

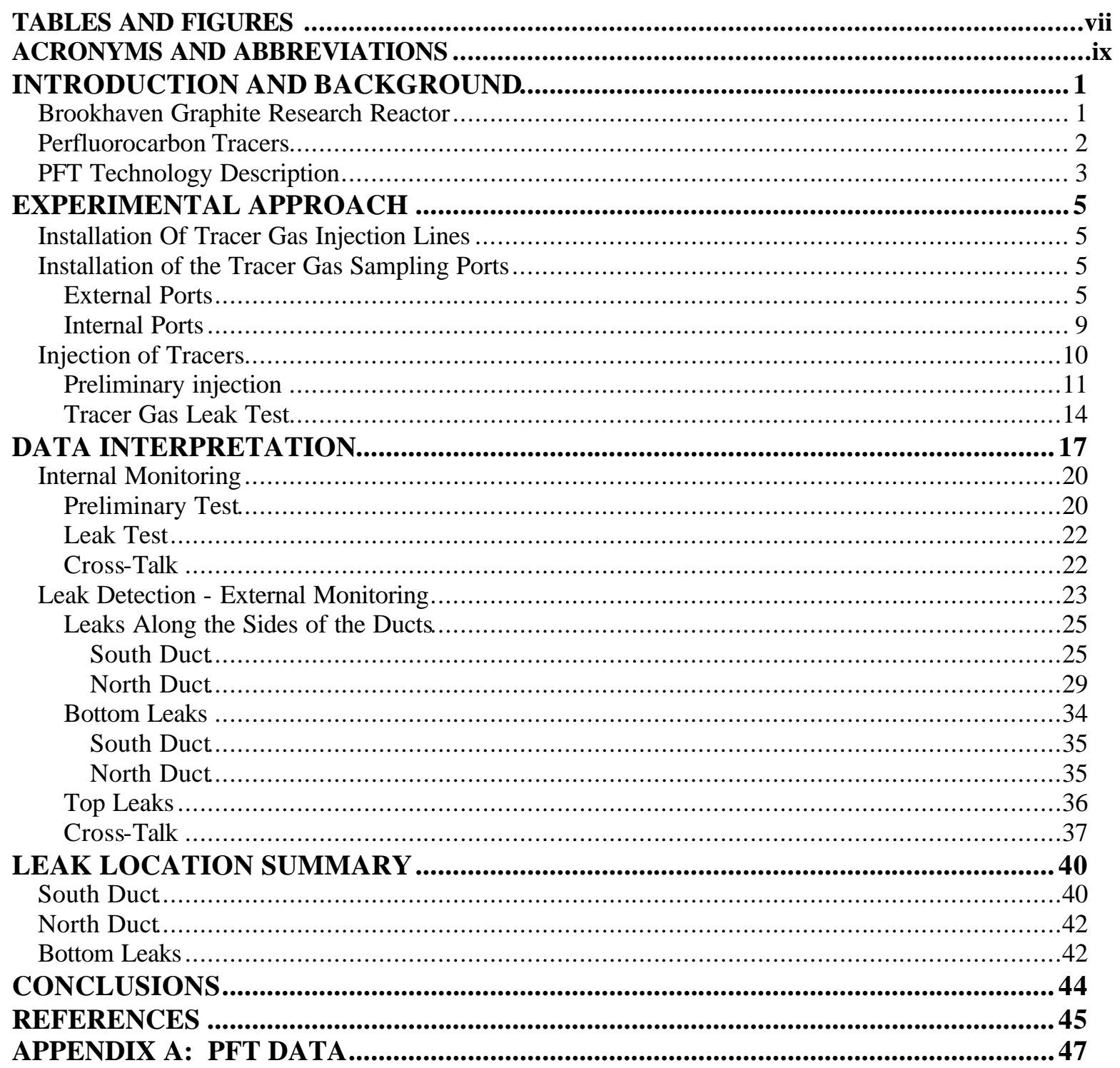




\section{TABLES AND FIGURES}

Figure 1. Schematic plan view of the BGRR Below Grade Ducts showing the gas circulation

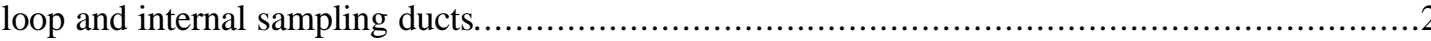

Figure 2. Schematic of leak detection using perfluorocarbon tracer technology .............................

Figure 3. Injection loop at the pump for south duct......................... Error! Bookmark not defined.

Figure 4. Schematic of external sampling port locations...................................................6

Figure 5. Geoprobeâ Model 54 LT continuous push soil-probing unit used to install monitoring ports in soil adjacent to the BGRR Below Grade Ducts ...................................................... 7

Figure 6. Bundle of sample ports showing the sintered glass filters attached to polypropylene

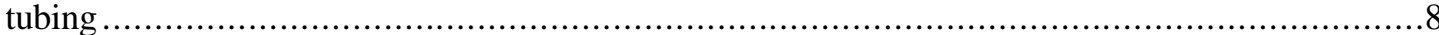

Figure 7. The underground electrical duct running along side the south cooling duct...................10

Figure 8. Geoprobe ${ }^{\circledR}$ installing ports along the south duct, between the electrical duct and main

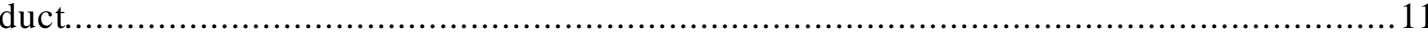

Figure 9. Flow meter connected to tracer inlet of the north air circulation loop ............................12

Figure 10. Air sample being collected at the south circulation loop ......................................... 13

Figure 11. Gas sample bag and pump used to collect air samples........................................... 13

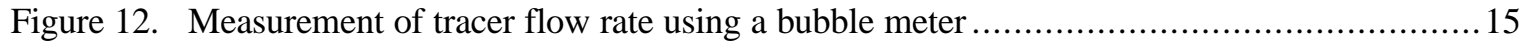

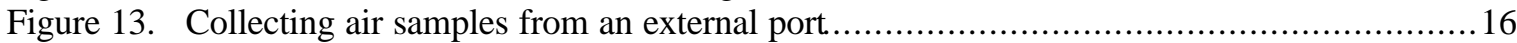

Figure 14. Injection of sample onto a Capillary Adsorbent Tracer Sampler (CATS).....................17

Figure 15. Gas chromatograph and CATS sample rack used to analyze samples for PFTs.............. 18

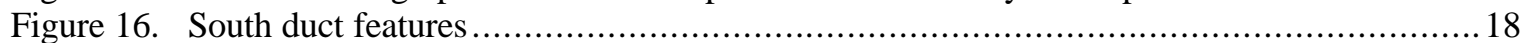

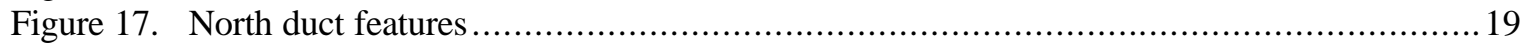

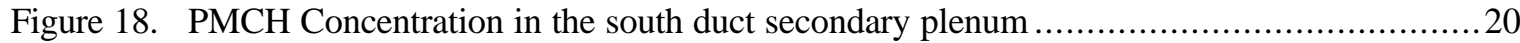

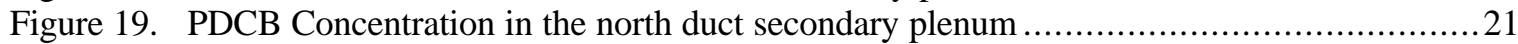

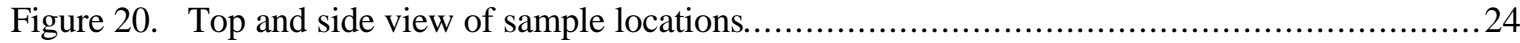

Figure 21. PMCH concentration contours the day after completion of the seven-day injection

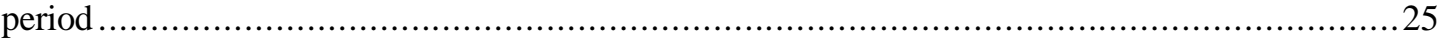

Figure 22. PMCP concentrations on the second and third day after the leak test injections were

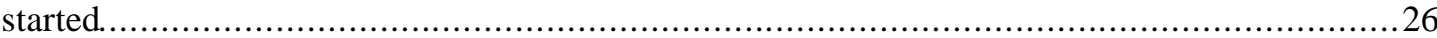

Figure 23. PMCP concentration on the fifth, seventh, and ninth day after the leak test was started....27

Figure 24. PMCP concentrations on the fourth and sixth days after injection was completed...........28

Figure 25. PDCB concentration contour at the end of the eight-day injection period, February

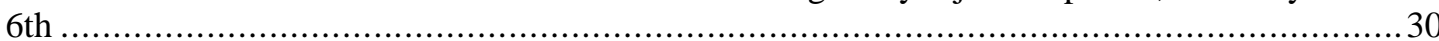

Figure 26. o-PDCH Concentrations on the first, third, and fifth day after the start of injection ...........31

Figure 27. o-PDCH concentrations at the end of the injection (February 16th), fourth (February

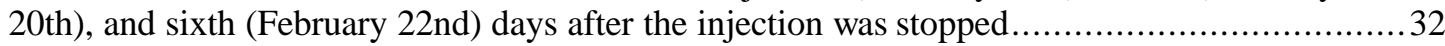

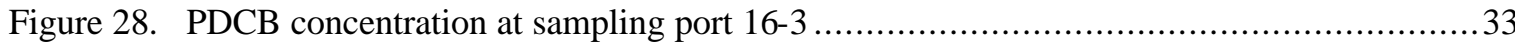

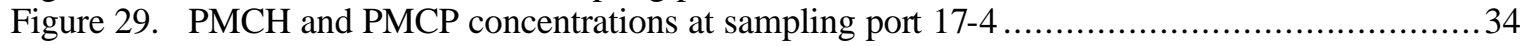

Figure 30. Sample locations with evidence of a leak along the bottom of the duct.......................35

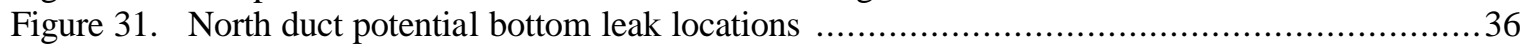

Figure 32. Example of PFT concentrations along the top of the two below grade ducts....................37

Figure 33. PMCH concentrations along the north duct one and four days after the injection was

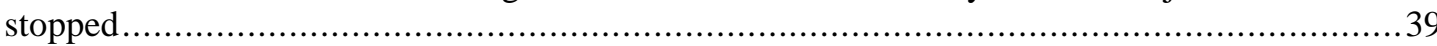

Table I Chemical acronym, name, and formula for PFT tracers used in this study..................11

Table II Comparison of tracer concentrations in the secondary plenum...............................22

Table III Potential leak locations along the south duct.................................................. 41

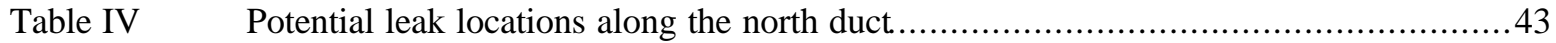




\section{ACRONYMS AND ABBREVIATIONS}

\begin{tabular}{ll} 
ASTD & Accelerated Site Technology Deployment \\
BGRR & Brookhaven Graphite Research Reactor \\
BNL & Brookhaven National Laboratory \\
CATS & capillary adsorbent tracer samplers \\
cc & cubic centimeter(s) \\
CDPTC & Canal deep pit tracer concentration \\
D\&D & Decontamination and Decommissioning \\
DDFA & D\&D Focus Area \\
DOE & U.S. Department of Energy \\
$\mathrm{ft}^{3}$ & cubic feet \\
GC & gas chromatograph \\
HEPA & high-efficiency particulate air \\
ml & milliliter \\
ml/min & milliliters per minute \\
NDBTC & North duct bottom tracer concentration \\
NDPTC & North duct primary tracer concentration \\
NLIP & North loop injection point \\
o-PDCH & orthocisperfluorodimethylcyclohexane \\
PDCB & Perfluorodimethylcyclobutane \\
PFT & perfluorocarbon gas tracers \\
PMCH & Perfluoromethylcyclohexane \\
PMCP & Perfluoromethylcyclopentane \\
ppb & parts per billion \\
ppm & parts per million \\
ppq & parts per quadrillion \\
PSTC & Pressure switch tracer concentration \\
PVC & polyvinyl chloride \\
SDBTC & South duct bottom tracer concentration \\
SDPTC & South duct primary tracer concentration \\
SLIP & South loop injection point \\
SRS & Savannah River site \\
\hline &
\end{tabular}




\section{INTRODUCTION AND BACKGROUND}

\section{Brookhaven Graphite Research Reactor}

The Brookhaven Graphite Research Reactor (BGRR) was the world's first nuclear reactor dedicated to the peaceful exploration of atomic energy. The reactor pile consisted of a 700-ton, 25-foot cube of graphite fueled by uranium. A total of 1,369 fuel channels were available with roughly half in use at any given time. Insertion and removal of boron steel control rods controlled reactor power levels. One or more of five fans powered air-cooling. Air was brought in through two filtered plenums, flowed through and around the reactor core, then through an exhaust duct containing filters, and finally out through the 320-foot high exhaust stack. Spent fuel was temporarily stored in the spent fuel canal, and then sent to the Department of Energy's (DOE) Savannah River facility (SRS). Access to the canal for removing spent fuel was through the Canal House (Building 709).

The BGRR ceased operation in 1968, and was placed in a shutdown mode. All fuel was removed and sent to SRS, and penetrations in the biological shield around the graphite cube and fuel channels were sealed. The final decommissioning process was initiated in 1999, and is currently scheduled for completion in 2005. An accelerated schedule was developed that combines characterization with removal actions for the various systems and structures. Before work on a section of the BGRR facility begins, measurements are taken to determine the types and amounts of contaminants present. The data are then used for project planning, including decisions affecting the extent of removal, waste designation and health and safety plans.

The focus of this aspect of the BGRR program, and specifically this Accelerated Site Technology Deployment (ASTD) project, is the characterization of the soils beneath the Below Grade Ducts connecting the exhaust plenums with the Fan House. The air plenums experienced water intrusion during BGRR operations and after shutdown. The water intrusions were attributed to rainwater leaks into degraded parts of the system, and to internal cooling water system leaks. As a guide to define regions where soil characterization is most needed, a leak test using perfluorocarbon gas tracers (PFT) was conducted. The tracers were injected into the air plenum and measured in the surrounding soils to determine potential leak pathways. This project is co-funded through the DOE Office of Science and Technology Accelerated Site Technology Deployment (ASTD) program through the D\&D Focus Area (DDFA) and by the BGRR Decommissioning Project.

Figure 1 depicts the layout of the BGRR duct facilities. The underground air ducts (plenums) are approximately 170 feet long, running from Building 701 (the Reactor Building) to the above ground joint. Each of the north and south exhaust air plenums are approximately ten feet wide and fourteen feet high.

The ducts are constructed of one-foot-thick reinforced concrete lined with two layers of carbon steel. The steel liners make up the primary and secondary ducts. The primary duct provided cooling air for the reactor; the secondary duct maintained counter-flow cooling to prevent overheating of the concrete. The bottom of the air-plenum concrete is at an approximate elevation of 75 feet mean sea level, about 35 feet below grade. The main air duct has five expansion joints, which are believed to be potential points for the release of contamination from the ducts to the environment. Additional information on the D\&D of the BGRR can be found at http://www.bnl.gov/bgrr/ and at http://www.dne.bnl.gov/ewtc/d\&d.htm.

If it can be demonstrated that the soils under the air plenum are not contaminated above the established regulatory criteria or require only a small amount of remediation, the concrete surrounding the contaminated air plenums may not have to be removed. This would result in a substantial cost savings to the project and could result in reduced waste volumes for off-site disposal as low-level waste. 


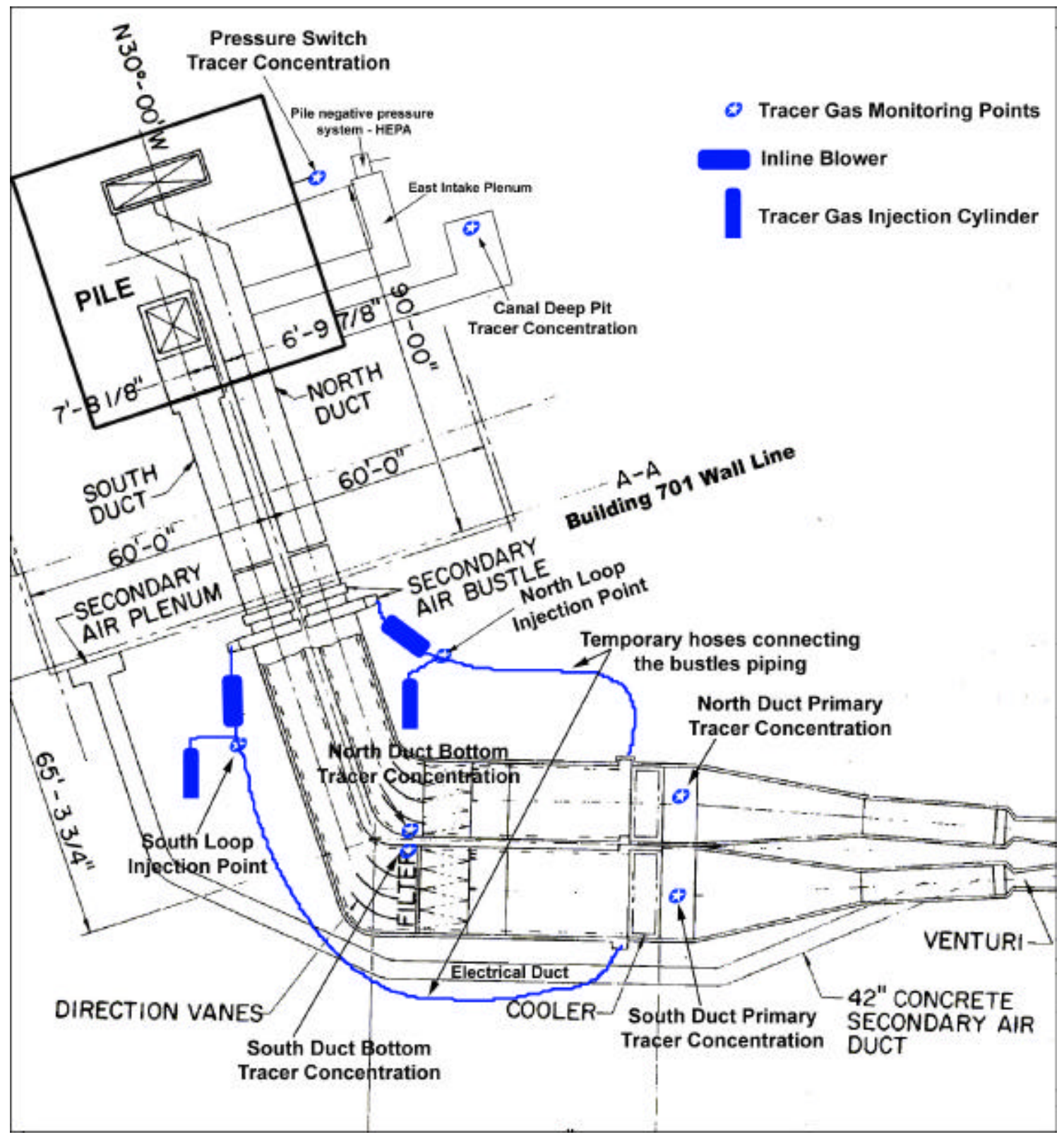

Figure 1. Schematic plan view of the BGRR Below Grade Ducts showing the gas circulation loop and internal sampling ducts

\section{Perfluorocarbon Tracers}

As part of the overall characterization efforts, a state-of-the-art gaseous perfluorocarbon tracer (PFTs) technology was utilized to characterize leak pathways from the ducts. This, in turn, allows determination of what soil regions under or adjacent to the ductwork should be emphasized in the characterization process. Knowledge of where gaseous tracers leak from the ducts yields a conservative picture of where water ingress or egress from the ducts might have occurred. 
Contamination of soils is expected to coincide with the water leak pathways out of the duct. The likely areas were believed to be the expansion joints, as determined from inspection of the duct blueprints and from internal video surveillance of the ductwork. Although every gas leakage location may not result in soil contamination (for example at the side or top of the duct), the likelihood of contamination occurring is highest in these areas. While the baseline soil characterization efforts emphasize the expansion joints, the PFT leak detection system was used to confirm these expectations, give a relative sizing of the leaks and to determine if unexpected leakage might have occurred at areas other than the expansion joints. This system uses gaseous PFTs and has been successfully deployed for other environmental applications (e.g., integrity verification in subsurface barriers) $(1,2)$.

A more exact determination of leak pathways has several advantages. PFTs were used to determine whether the suspect areas have, in fact, leaked (and the relative magnitude of the leaks) but more importantly were used to determine if any additional areas of the ducts have leaked (e.g., due to significant cracks in the concrete ducts). This information can then be integrated into the Below Grade Duct Sampling and Analysis Plan (SAP) and provide the basis for biased sampling, i.e., higher frequency of samples in areas of higher probability of contamination. Likewise, areas that are shown not to have leaked can be de-emphasized in the SAP, reducing the number of samples required and reducing the cost.

\section{PFT Technology Description}

Brookhaven National Laboratory (BNL) has developed a suite of PFTs. These tracers were originally used in atmospheric and oceanographic studies and have since been applied to a great variety of problems, including detecting leaks in buried natural gas pipelines and locating radon ingress pathways in residential basements $(3,4)$. PFTs have regulatory acceptance, and are used commercially (e.g. detecting leaks in underground power cable systems). PFTs allow locating and sizing of leaks at depth, have a resolution of fractions of an inch and have been used in a variety of soils.

A tracer is any substance that can be easily or clearly monitored (traced) in the study media. Tracer technologies can be used in transport/dispersion studies, leak detection studies, and material location. Leak detection studies use tracers to locate and estimate leak rates in various scenarios. These can be as simple as colored dyes used to visually locate cracks and holes in tanks or as complex as mass spectroscopy detection of helium to find leaks in vacuum systems. In transport and dispersion studies, tracers are used to tag a medium to determine how it is being dispersed in a surrounding matrix.

PFT technology consists of the tracers themselves, injection techniques, samplers, and analyzers. PFTs have the following advantages over conventional tracers:

- Negligible background concentrations of PFTs in the environment. Consequently, only small quantities are needed.

- PFTs are nontoxic, nonreactive, nonflammable, environmentally safe (contain no chlorine), and commercially available.

- PFT technology is the most sensitive of all nonradioactive tracer technologies and concentrations in the range of 10 parts per quadrillion of air (ppq) can be routinely measured.

PFT technology is a multi-tracer technology allowing up to six PFTs to be simultaneously deployed, sampled, and analyzed with the same instrumentation. This results in a lower cost and flexibility in experimental design and data interpretation. All six PFTs can be analyzed in 15 minutes on a laboratorybased gas chromatograph. 
Very small leaks are easily identified because PFTs can be detected at extremely low levels. Leaks in the BGRR Below Grade duct were located by injecting the PFT(s) inside of the duct and monitoring for that tracer(s) outside of the duct (see Figure 2). Where and how much of the tracer was detected on the monitoring side of the duct helped estimate the location and size of any leaks. Larger openings in the duct mean that greater concentrations of tracer are transported out more rapidly. The injection and monitoring of the tracers were accomplished using conventional low-cost monitoring methods, such as multilevel sampling ports, placed using cone penetrometer (Geoprobe $\left.{ }^{\circledR}\right)$ techniques.

\section{Perflourocarbon Tracer Technology}

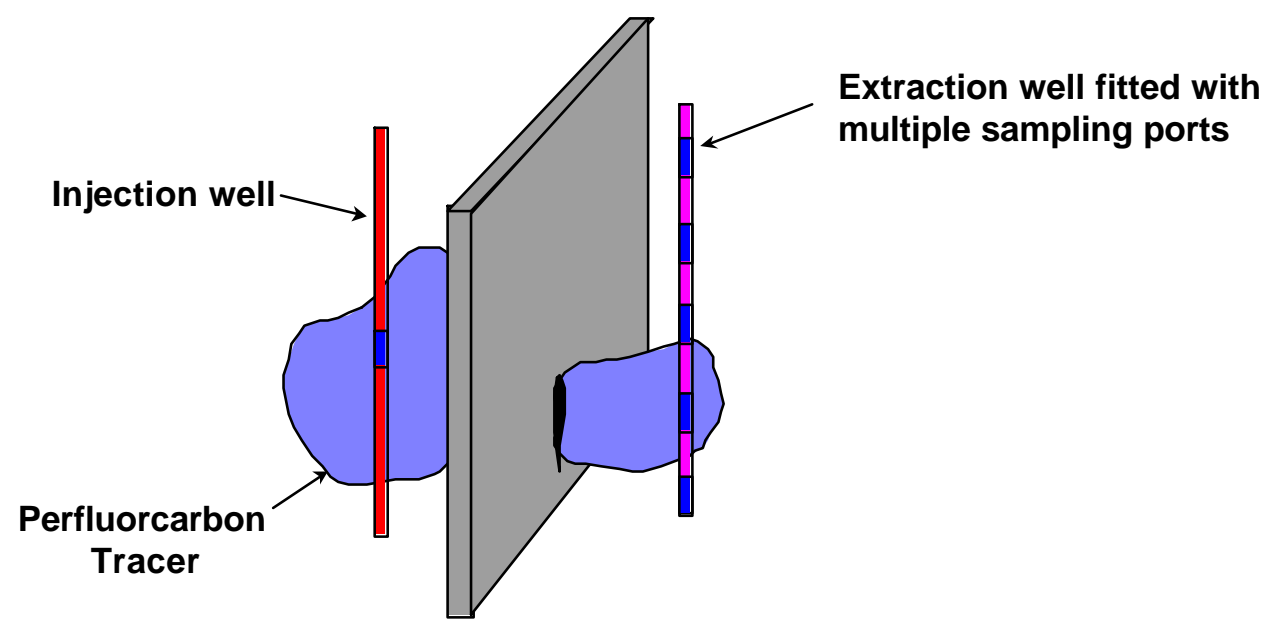

Figure 2. Schematic of leak detection using perfluorocarbon tracer technology

The PFTs can be collected in air sampling bags and or on capillary adsorbent tracer samplers (CATS), which is a small cigarette sized glass tube containing a carbonaceous adsorbent specific for the PFTs. A CATS can be used dynamically (flowing a sample through the CATS), or passively (opening only one end to allow the CATS to sample by diffusion). The passive mode allows a time integrated PFT concentration to be measured in a simple manner. The CATS are shipped back to the laboratory for PFT analysis.

With gas sample bags, the sample is collected in the field using a compatible pump. The bag is sent to the analytical laboratory where a small sample is withdrawn from the bag using a syringe and injected onto a CATS. The CATS is then placed on an automated gas chromatograph for analysis. Additionally, several real-time PFT analyzers are available, one that detects four different PFTs down to the ambient background of the PFTs in air (in a five minute sample). 


\section{EXPERIMENTAL APPROACH}

\section{Installation Of Tracer Gas Injection Lines}

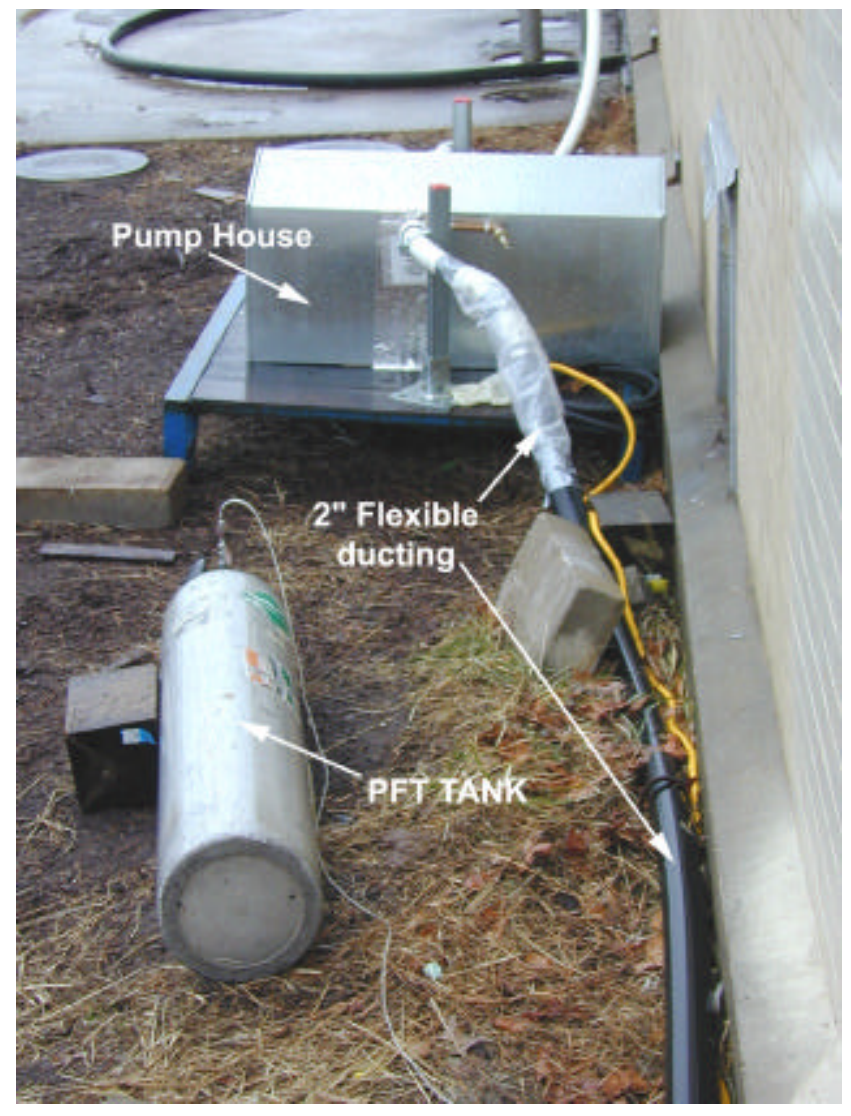

The PFTs were introduced into the interior volumes of the below grade ducts through the secondary air system outer cooling channels. The primary ducts carried air cooling from the reactor to the Fan House. The secondary cooling ducts circulated cooler air around the primary ducts. This was done to keep the concrete outer portion of the ducts at a reasonable temperature to avoid dehydration damage. Since any leakage from the below grade ducts would have to travel through the secondary cooling ducts, contamination that might have escaped from the primary ducts would be detected in the secondary ducts.

Access to the channels was from the air bustle and below grade vault. Separate inlet and outlet flexible ducting (2-inch inside diameter) was installed to provide isolated circulation loops for the north and south outer ducts (see Figures 1 and 3). Separate circulation loops allowed different tracers to be circulated in each duct, which gave better differentiation of leaks from the two ducts. Greaseless pumps where used to circulate the air in the secondary ducts. The flow rate in each secondary plenum was approximately $10 \mathrm{ft}^{3}$ per minute, which

Figure 3. Injection loop at the pump for south duct provided one complete volume exchange every 200 minutes or seven complete volume circulations per day in the south secondary plenum, and 12 volume exchanges per day in the smaller north secondary plenum. The tracer gas cylinders were connected to the circuits to allow injection of the PFTs.

\section{Installation of the Tracer Gas Sampling Ports}

\section{External Ports}

As mentioned earlier, PFTs were injected inside of the ducts and detected in monitoring ports outside of the ducts. The concentrations on the outside were then related to the integrity of the ducts. The monitoring ports needed to be in close proximity to the ducts to increase accuracy by minimizing the transport time to the ports and minimizing dilution effects. Figure 4 shows the monitoring locations. This diagram depicts the below grade ducts from the secondary bustle to the coolers (to see how this fits into the reactor layout and overall air-ducts, see Figure 1). 
- Single depth port location

+ Added single depth location

\&-Multi-depth port location

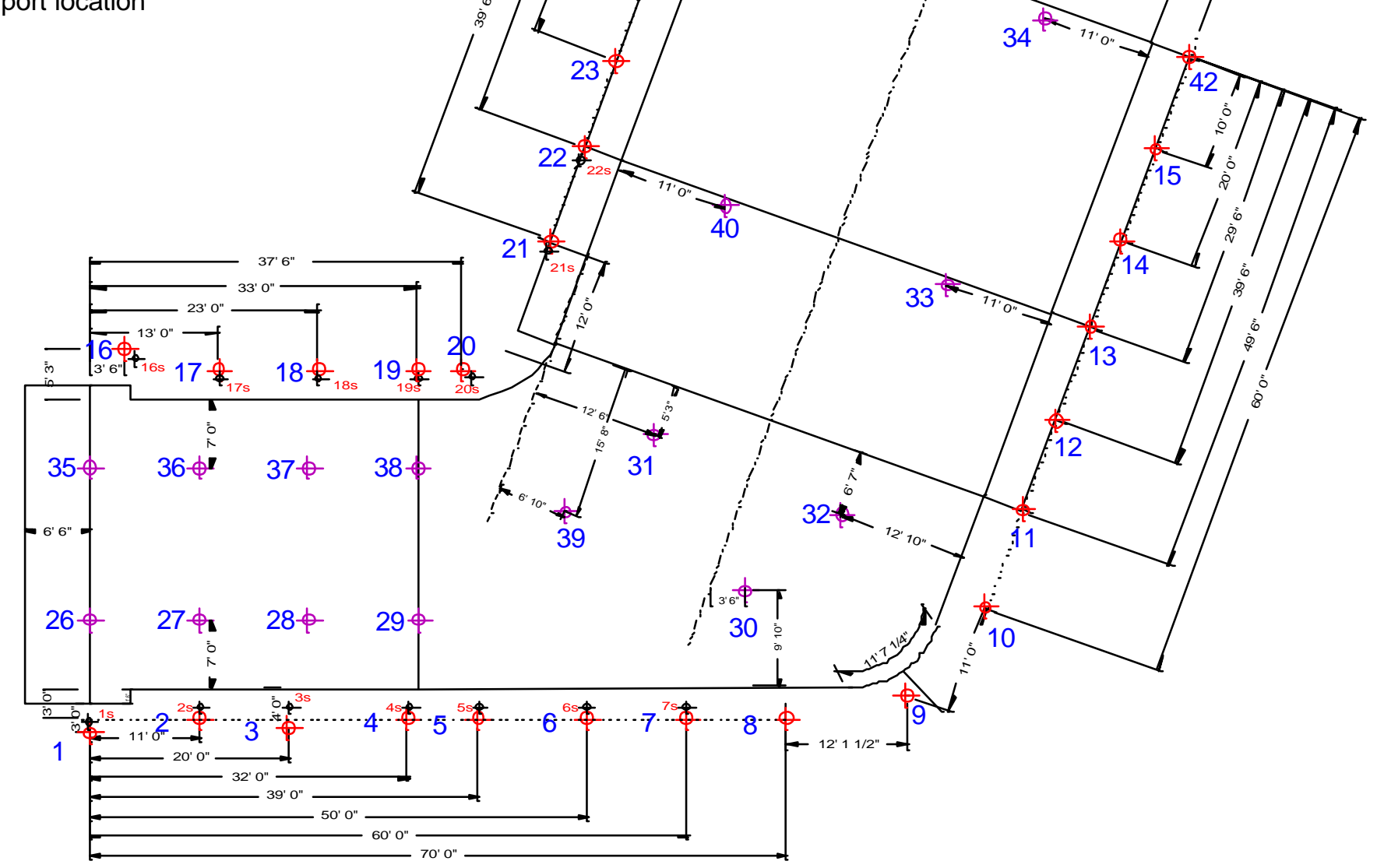

Figure 4. Schematic of external sampling port locations 
Boreholes were placed along both sides of the ductworks and along the central axis of each individual duct. The monitoring boreholes along the sides have three to five sampling ports each, evenly spaced vertically every five feet. The first or deepest port is at the same elevation as the bottom of the exterior of the ductwork. The air plenum rests on a 2'10" concrete base, therefore, this port is below the bottom of the air plenum. The last port at the same location is near the top of the air plenum. After installing the initial port bundles (described later) it was decided that an additional ports would be very easy to install and another set of single port tubes were placed. These ports are located at the top of the exterior of the ducts and are designated with an "S" on the map. These locations are set one foot away from the original locations and are very shallow. Only the single port located even with the top of the ducts needed to be installed so the deepest " $\mathrm{S}$ " (for shallow) port is less than eight feet deep and the shallowest only three feet below grade. The sampling ports were placed approximately three feet from the duct wall. The monitoring boreholes that run along the spine of the two individual ducts each have one sample port located one to three feet above the duct.

The boreholes were placed using a Geoprobe ${ }^{\circledR}$ Model 54 LT continuous push soil-probing unit (Figure 5). This unit is basically a hydraulically-driven penetrometer that was used to push a 2.125 -inch outer diameter steel rod into the subsurface at each monitoring well location. The rod was then withdrawn and the resulting hole used for installation of the monitoring ports. The ports themselves are of simple design (see Figure 6): a sintered glass filter, to prevent plugging, was attached to a length of 0.125 in polypropylene tubing. Several ports are bundled together, each having a different length of tubing. The bundle of ports was then lowered into the borehole until the first port reached the desired depth. Once the filter was in place, the hole was backfilled with a blended-sand mix. The sand was used to prevent vertical cross-talk from port to port and to prevent advective currents in the borehole. Backfilling was completed by slowly pouring sand down the 2.125 -inch hole. The sand firmly held all the ports in place and kept them at the desired depths.

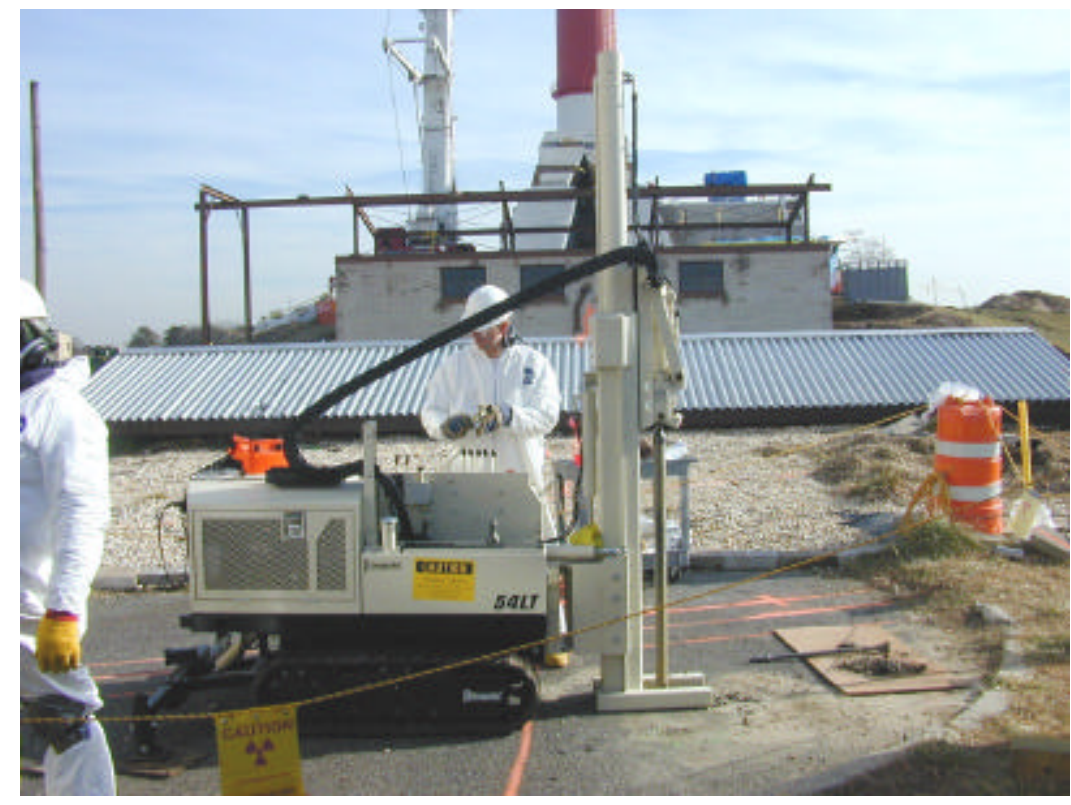

Figure 5. Geoprobe ${ }^{\circledR}$ Model 54 LT continuous push soil-probing unit used to install monitoring ports in soil adjacent to the BGRR Below Grade Ducts 
The ends of the monitoring port access tubes (attached to the filters) extend to the surface to allow sampling of the soil gases. The polypropylene tubing was protected using short lengths of twoinch polyvinyl chloride (PVC) pipe. The pipe was placed over the tubing and into the top of the borehole as the last foot of borehole was being backfilled.

The planned layout of the sampling locations was marked on the ground with field paint. Prior to posting the area the Geoprobe ${ }^{\circledR}$ was positioned in the area to be probed. The area around each penetration point (or set of points that were close together) was marked as a potential contamination area and appropriate precautions were taken whenever working in the area. The penetrometer was positioned over the mark, leveled and the probe rod was set plumb. The probe rod was then slowly pushed into the soil about one foot and the level and plumb rechecked. If the location was on asphalt or concrete, the mark was pre drilled using a drill bit on the Geoprobe ${ }^{\circledR}$. Once the drill bit penetrated the asphalt or concrete, the bit was exchanged for a push rod. The push rod was driven into the ground using a combination of push and hammer blows. At most locations around the ducts the hammer was only sporadically needed. Every four feet another push rod was added to the last until the desired depth plus two feet was reached. The additional two feet was to allow for any soil that might collapse back into the hole. This method worked quite well and only one hole needed to be re-probed because soil had collapsed back into the hole to the point that the ports could not be installed to the proper level.

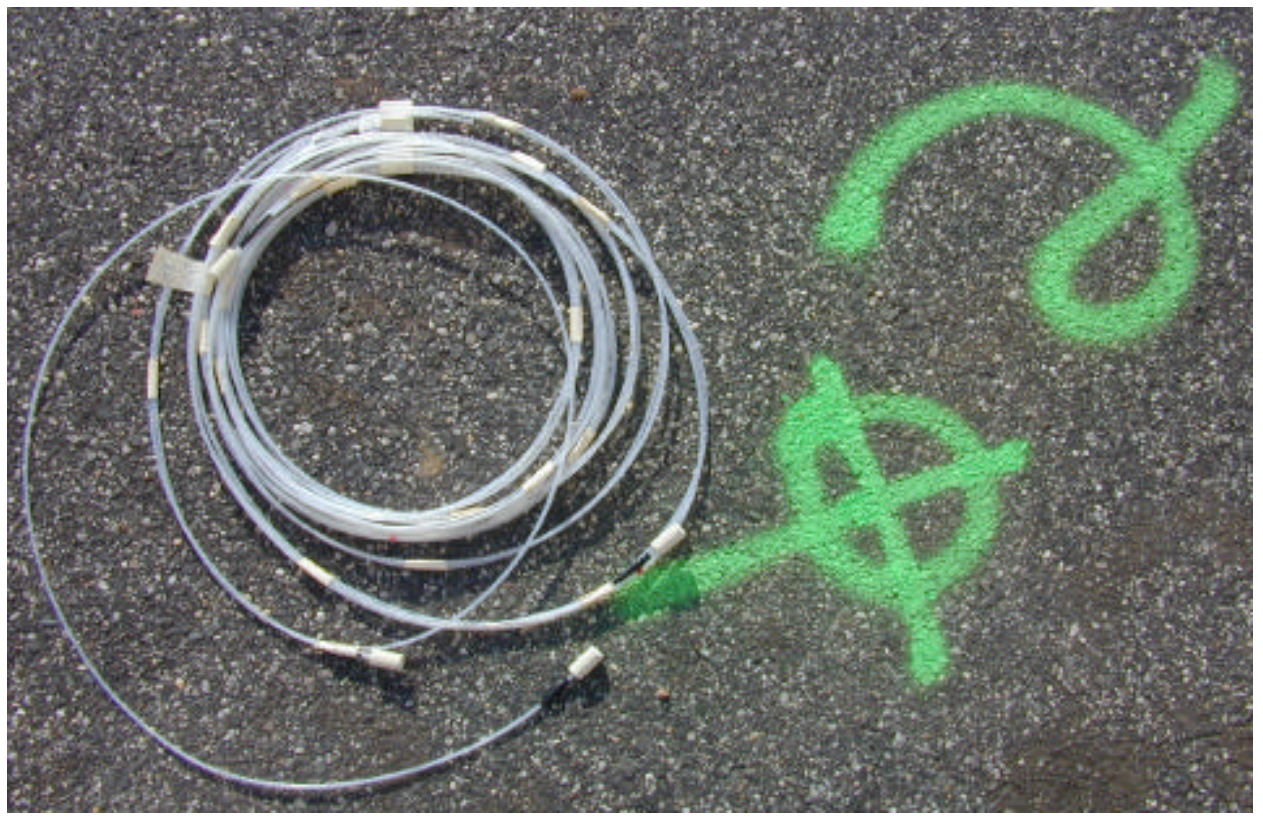

Figure 6. Bundle of sample ports showing the sintered glass filters attached to polypropylene tubing

Upon reaching depth, radiological control personnel were notified and the withdrawal procedure began. As each four-foot section of rod was withdrawn, it was wiped down with a mausolin cloth. The radiological control representative frisked the cloths for contamination and the process continued until all the rods were withdrawn from the ground. The port bundles were installed and the holes backfilled. The equipment was then smeared and checked for contamination by the radiological control representative. After counting the smears, radiological control personnel released the site and the Geoprobe ${ }^{\circledR}$ was moved to the next location. None of the penetrations brought contamination up from the subsurface. This was as 
expected since we were probing about three to four feet away from the ducts and not going more than two feet below the duct. Contamination was expected to be mainly below the ducts and in very close proximity.

Several holes had complete refusal at the marked location. When this occurred, the procedure was to move one foot left (remaining the same distance from the duct) and try again. If refusal occurred again, the procedure called for moving one foot to the right of the original location and trying again. Further refusal would have led to trying one foot closer to the duct, then one foot further away, then two feet right, two feet left and so on until the borehole could be placed. Monitoring bundle \#3 is one foot further away and one foot to the left of its planned location; a wing wall (stabilizing component) off the main duct most likely caused the refusal. Bundles \#4 and \#5 are one foot left of their planned locations. Bundle \#20 was the most affected locale; it was moved almost five feet. Continued refusal at about two feet in depth at the planned location led to a decision to hand dig to determine the cause of the refusal. An undocumented cement footing at least one foot thick was discovered. The footing/slab was uncovered until the edge of the slab was located. Location 20 was then moved to that area. All other bundles were installed at their planned location with the exception of location 16. There was an above-ground obstruction (a cement manhole) that prevented the Geoprobe ${ }^{\circledR}$ from placing the borehole at its optimal location. The borehole was moved three feet right and 2.5 feet further out from the ducts to accommodate the manhole. The port location map shown in Figure 4 has the corrected locations marked, that is, it is an as-built schematic.

Locations 8 to 15 and 42 are all along the south duct. In this region, there is a buried underground electrical duct that is two feet by two feet and runs parallel to and within one foot of the south duct. This electrical duct remains close to the below grade ducts from the cooler to the filter house. Past the filter house it diverges away from the south duct. To avoid damaging the electrical duct, the soil next to the south duct from location 8 to 42 was excavated to the top of the electrical duct. Five feet of soil was removed to uncover the duct. This area was designated a contamination zone during the excavation and later cleared. No contamination was found in any of the soil samples tested. Again, this is as expected since this is the upper third of the cooling ducts. The track-mounted Geoprobe ${ }^{\circledR}$ was driven into the trench (which had a side-slope greater than $45^{\circ}$ ) and the probing was completed. The boreholes were placed between the two ducts. Figure 7 shows the electrical duct unearthed and Figure 8 shows the Geoprobe $^{\circledR}$ in the trench.

\section{Internal Ports}

PFT concentrations inside the secondary ducts, primary ducts, canal deep pit and reactor pile were sampled via a series of eight internal sampling ports. All of the internal sampling ports had highefficiency particulate air (HEPA) filters attached to the outlets. This allowed samples to be drawn through the filter and prevented any internal contamination from entering the sample bags and being spread to the analytical laboratory.

Two ports were installed as part of the gas circulation loops, one at the south duct fan (designated SLIP for "south loop injection point") and one at the north duct fan (designated NLIP for "north loop injection point"). Two more ports were installed into the north and south ducts at the third expansion joint located just before the filter house (designated NDBTC for "north duct bottom tracer concentration" and SDBTC for "south duct bottom tracer concentration", respectively). Installation of NDBTC and SDBTC was completed by uncovering the expansion joint near the midpoint (where the north and south ducts meet) and drilling through the steel plate. Copper tubing, 0.25 inch in diameter, was inserted into each duct and sealed with a silicon caulking. These four ports measured the PFT concentration inside the secondary ducts. The two at the fans measured the concentration at the beginning of the circulation loop. The two ports at the expansion joint measure the concentrations at the midpoint of the circulation loop. 
It was also necessary to measure the concentrations of PFTs within the primary cooling ducts. It was known that the primary duct had corroded through at several points and therefore cross contamination of PFTs from the secondary to the primary would occur. By measuring the concentrations in the primary ducts we could determine the extent of the cross-talk between the primary and secondary ducts and control the injection rate of tracers to keep the secondary ducts at the desired levels. Two sampling lines already existed in the cooler building. These were utilized to sample the primary ducts and were designated NDPTC for "north duct primary tracer concentration" and SDPTC for "south duct primary tracer concentration" for the north and south ducts, respectively. Again, copper tubing was run from the sample ports through a HEPA filter.

The seventh internal port used existing plumbing from a pressure switch to sample the air inside the reactor pile (designated PSTC for "pressure switch tracer concentration"). The pile, while not part of the leak test, provides a huge "dead" space that could dilute the tracers. It was expected that the pile would have only a small influence on the tracer concentrations in the secondary ducts, but there is direct connection (albeit a long and convoluted pathway) between the two and the effect needed to be quantified. The last port was installed in the deep canal pit (designated CDPTC for "canal deep pit tracer concentration") for the same reasons as the pile sample port, namely the deep canal is open to the duct work and represents possible dilution of the PFTs.

\section{Injection of Tracers}

Two injections of tracers were performed. The first, termed the preliminary injection, was designed to determine the degree of leakage and cross-talk within the duct system and confirm the appropriate tracer gas flow rates. This test would also provide information on sizing and sample frequency requirements for the second injection. The second injection of tracers was strictly a leak test, designed to determine the leak paths out of the below grade ducts. The tracers employed are listed in Table I.

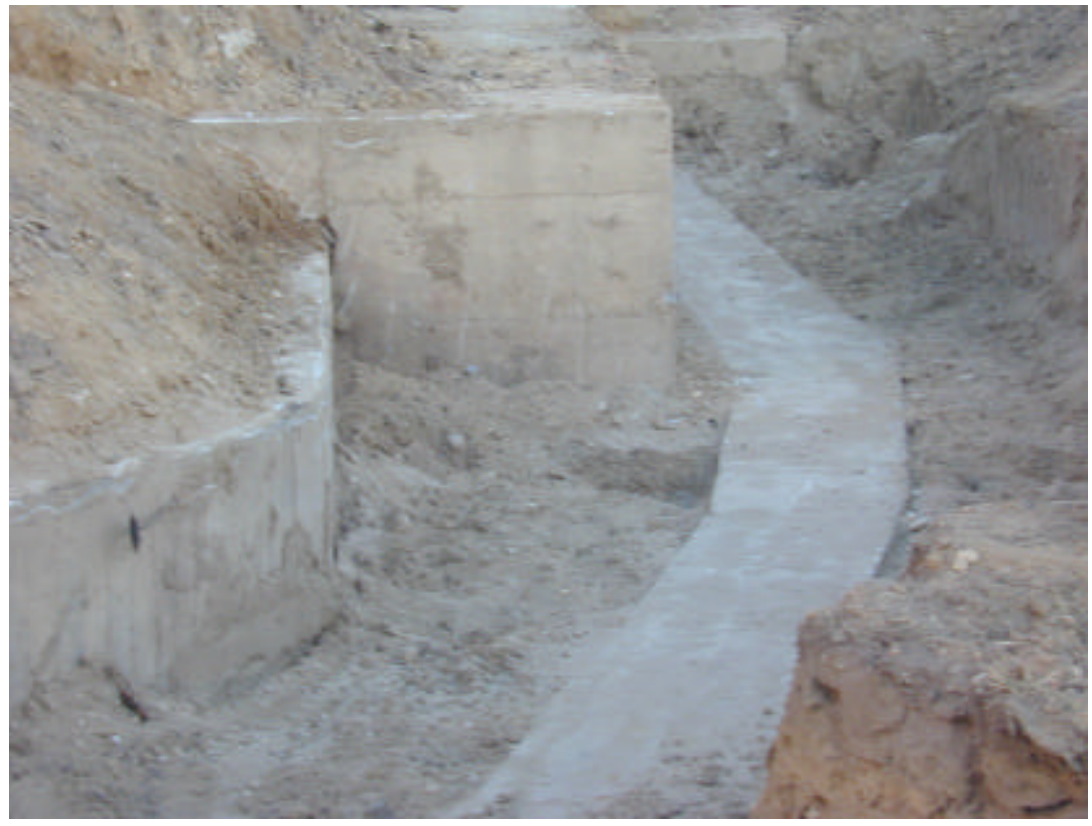

Figure 7. The underground electrical duct running along side the south cooling duct 


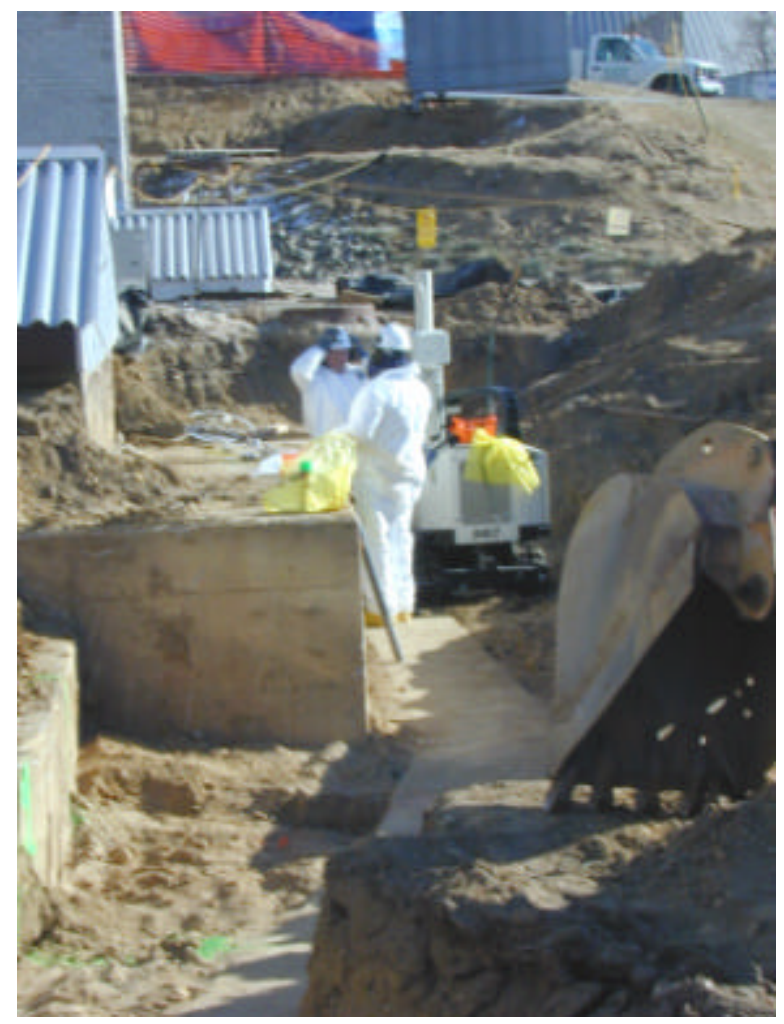

Figure 8. Geoprobe ${ }^{\circledR}$ installing ports along the south duct, between the electrical duct and main duct

Table I: Chemical acronym, name, and formula for PFT tracers used in this study

\begin{tabular}{|l|l|l|}
\hline Chemical Acronym & Chemical Name & $\begin{array}{l}\text { Chemical } \\
\text { Formula }\end{array}$ \\
\hline PDCB & Perfluorodimethylcyclobutane & $\mathrm{C}_{6} \mathrm{~F}_{12}{ }^{\text {(a) }}$ \\
\hline PMCP & Perfluoromethylcyclopentane & $\mathrm{C}_{6} \mathrm{~F}_{12}{ }^{\text {(a) }}$ \\
\hline PMCH & Perfluoromethylcyclohexane & $\mathrm{C}_{7} \mathrm{~F}_{14}$ \\
\hline o-PDCH & orthocisperfluorodimethylcyclohexane & $\mathrm{C}_{8} \mathrm{~F}_{16}$ \\
\hline
\end{tabular}

a) PDCB and PMCP are chemically distinct isomers

\section{Preliminary injection}

The secondary cooling ducts, as mentioned earlier, surround the primary ducts and originally there was no inter-connectivity. After years of operation followed by decades in shutdown/inoperative mode, corrosion of the metal between the primary and secondary has occurred. This was confirmed during pressure checks and visual (remote video) inspections. This has created pathways for cross flow and cross contamination. This could affect the tracer study by providing a dilution of the tracers injected into the secondary plenum. Air from the primary duct could be transported into the secondary duct through the holes caused by the corrosion. The transport could be by forced flow or diffusion. It was important to quantify the effective dilution of the tracers in the secondary duct so that we would inject enough tracer to get meaningful concentration levels in the soils outside of the ducts. 
Cross-talk between the primary and secondary ducts is the principle mechanism for dilution of the tracers but is not the only one. The reactor pile, canal deep pit, and intake plenums all had "dead" space volumes that were remotely connected to the ducts. This is why sample ports were placed in the reactor pile and canal deep pit. Access to the intake plenums was limited and sampling here was of low importance, so those areas were ignored. The contribution of the intake plenums would be similar to the reactor pile and canal pit and sampling them would yield redundant data.

The rate of gas injection was determined based on the volume of the cooling channel, the source concentration of the tracer (100 to 1000 parts per million [ppm]), expected diffusion rates and engineering assumptions about the cross-talk between the primary duct and reactor pile volumes with the secondary cooling ducts. The north and the south ducts are isolated from each other, therefore a different tracer was used in each cooling duct. This yielded data that is specific for each duct and helps to more accurately define transport pathways. PDCB tracer was injected into the north secondary-duct at an average injection rate of 19.1 milliliters per minute $(\mathrm{ml} / \mathrm{min})$. PMCH was injected at a rate of $9.1 \mathrm{ml} / \mathrm{min}$ into the south secondary duct. The injection of tracers began on January 30, 2001 and ended February 6, 2001. The flow rates of the tracers were monitored daily during injection of tracers. Figure 9 shows the flow rate being measured at the north injection loop using a hand-held electronic flow-meter.

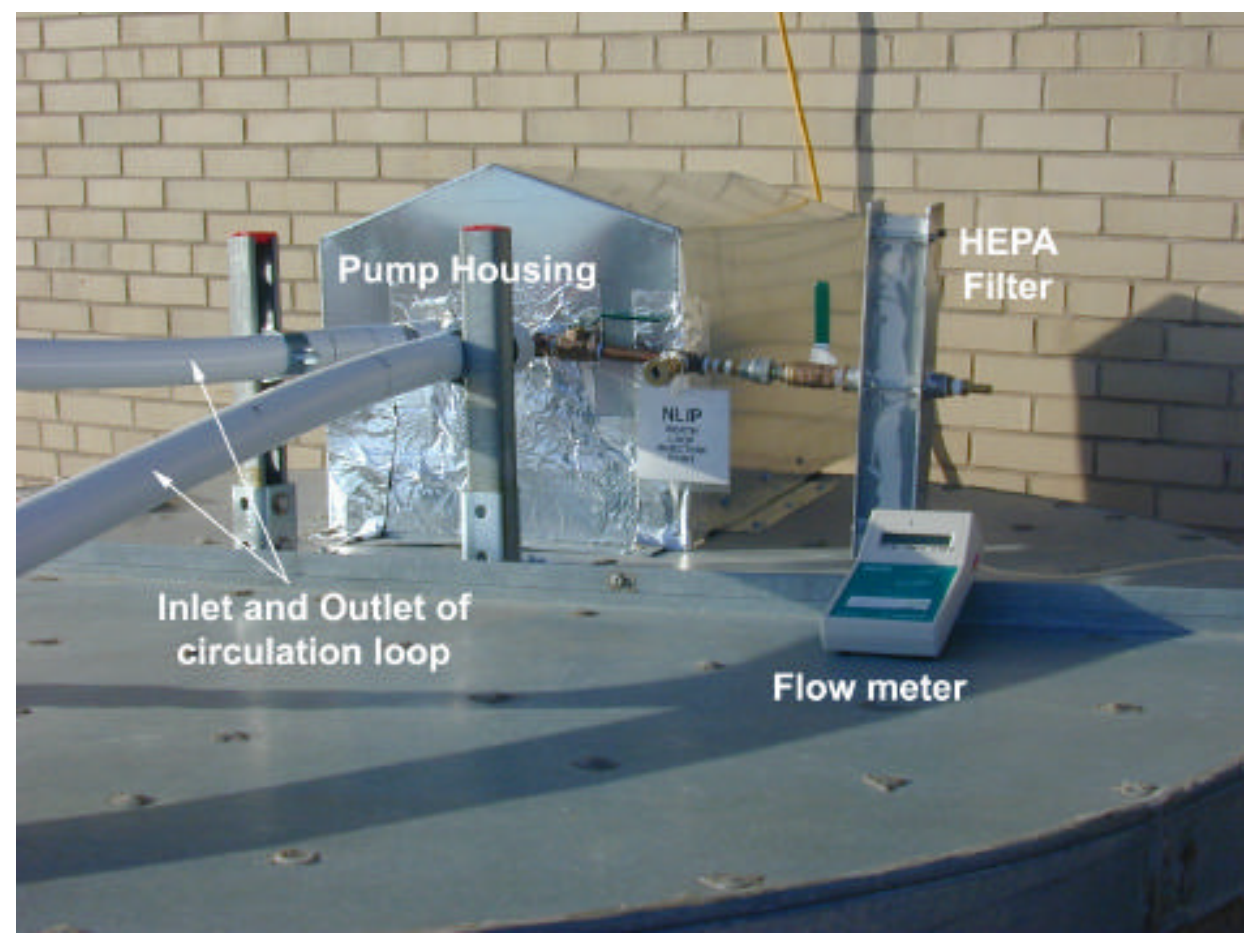

\section{Figure 9. Flow meter connected to tracer inlet of the north air circulation loop}

The target goal inside the secondary cooling channel was a tracer concentration in the range of $1 \mathrm{ppm}$ and was determined through modeling based on the expected diffusion rates through soil and concrete as seen in previous deployments. The internal tracer concentrations were measured by taking air samples from the internal ports. A small electric air pump was attached to the HEPA filter outlet via a tygon tube. The valve to the HEPA was opened and the pump turned on. The tubing, pump, and HEPA filter were purged for one minute and then the outlet of the pump was attached to the inlet valve of an air sampling bag and the valve to the bag was opened. The air-sampling bag was filled at a rate of approximately one liter per 
minute to a volume of 500 to $1000 \mathrm{ml}$. The typical chemical analysis used one $\mathrm{ml}$, and prior field experience had determined that a maximum of $50 \mathrm{ml}$ would be required for analysis. The pump was controlled by a Variac variable voltage controller to allow throttling the pump and provided an adjustable flow rate. The valve to the bag was shut when an appropriate volume was obtained, then the pump was turned off and the valve to the HEPA closed. The sample bags were then sent to an on-site analytical laboratory for chemical analysis (described later). Figure 10 shows a sample being taken at the south injection loop. Figure 11 shows a close-up of the sampling pump and the sample collection bag.

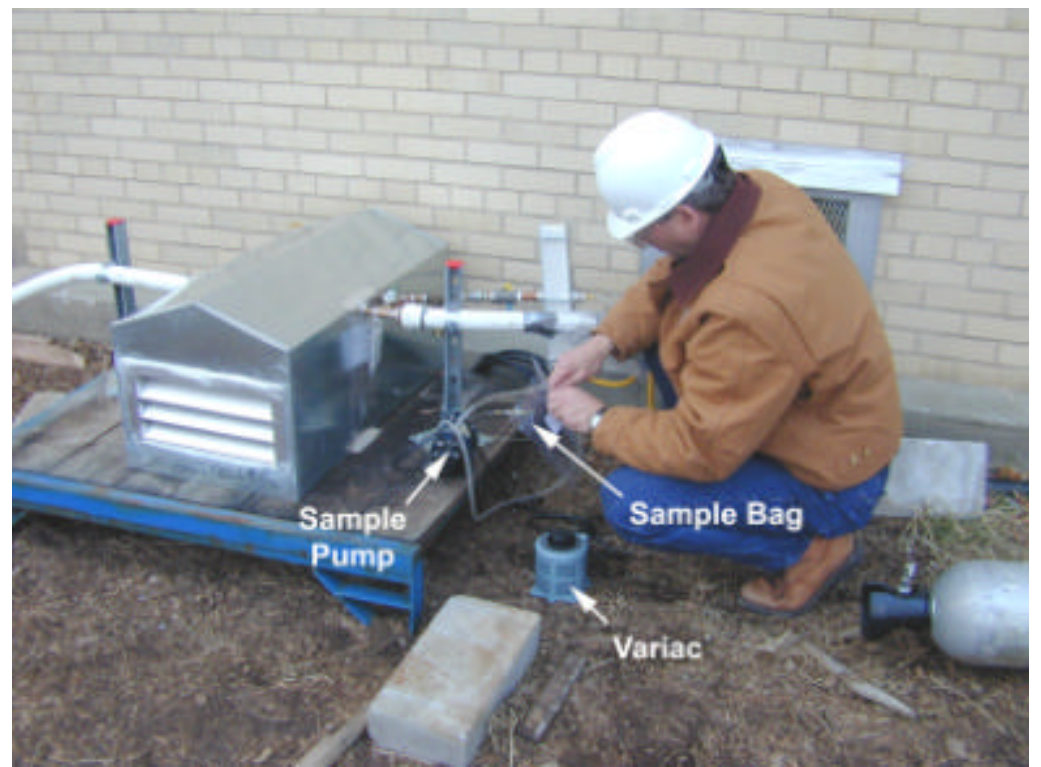

Figure 10. Air sample being collected at the south circulation loop

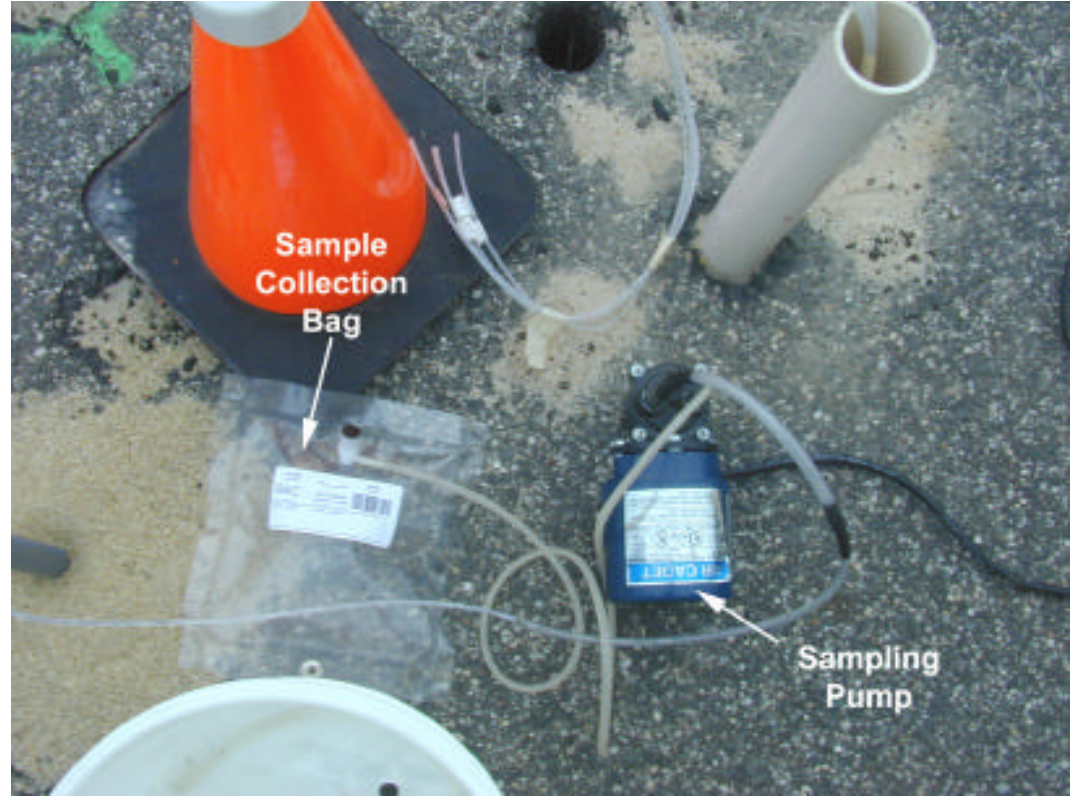

Figure 11. Gas sample bag and pump used to collect air samples 
Overall the "dead" space of the primary cooling duct, the reactor pile, canal deep pit and intake manifolds had only a minor diluting effect on the tracers. It was not necessary to change flow rates or injection parameters for the final injection test.

During the initial stages of the preliminary injection test only the internal spaces were sampled because the primary interest was to determine the rate of rise in tracer concentration within the ducts and the degree of cross contamination within the duct system. To improve our knowledge on the transport of the PFTs out of the ducts and through the soils, the external ports were sampled beginning on February 6. This was the day the tracers were turned off. Sampling was initiated to capture the decay curve of the tracers as they diffused away. This data would give a firm handle on the frequency needed for sampling and the time period that sampling should be continued. Sampling (all external and internal ports) was performed every other day (from the sixth day on) to fully develop the decay curve. This allowed us to estimate how long we would need to inject for the leak test. Originally, the leak test was planned to last 14 days, but the decay curve data led us to reduce this to nine days. Compilation of the decay curve data was performed concurrent with the leak test. The leak test was begun the day following termination of injection of the PDCB and PMCH tracers; the description follows.

\section{Tracer Gas Leak Test}

The leak test was started on February 7, 2001 with the introduction of two new tracers into the north and south ducts. Since the PFTs have multiple tracers that can be independently analyzed we did not have to wait for the tracers from the preliminary test to dissipate. Two new cylinders were delivered to the site and connected to the injection loops. PMCP was injected into the south duct and what was thought to be o-PDCH was injected into the north duct. The flow rate of the PMCP was $0.2 \mathrm{ml} / \mathrm{min}$ and was checked with a bubble meter, as the electronic meter was not accurate at such low flow (see Figure 12). Flow at the north duct was set at $8.3 \mathrm{ml} / \mathrm{min}$. The target concentration for the PFTs was $100 \mathrm{ppb}$. The original target concentration for the preliminary test was one $\mathrm{ppm}$, but the actual concentration was $0.1 \mathrm{ppm}$. The level seen outside the ducts was high enough for easy chemical analysis. A decision was made to keep the internal concentrations for the leak test at similar levels to the preliminary test. This would avoid procurement delays in obtaining higher concentration PFTs and minimize tracer gas usage.

The data from the preliminary test showed transport to be fairly rapid. For this reason sampling of the external and internal ports was performed on alternating days starting 24 hours after injection began. On the first day only the bottom ports of each location were sampled. This was done to screen the sample locations to see when tracers began to arrive at measurable levels. From this first set of samples it was determined that sampling every other day would be sufficient. Also, at this point we realized that no oPDCH was being detected and too much PMCP was being detected in the north duct. The analytical laboratory that supplied the tracers was brought to the site to directly sample the tracers in the tanks. It turned out that the laboratory had mis-labeled the o-PDCH tank. The cylinder, in fact, contained PMCP. The cylinder at the north injection loop was changed on February 9. A cylinder, confirmed to have o$\mathrm{PDCH}$, was attached to the circulation loop and the flow rate was set at $1.9 \mathrm{ml} / \mathrm{min}$.

Sampling of all external and internal ports was completed on February $10^{\text {h }}, 12^{\text {th }}$, and $14^{\text {th }}$. At this time a consistent picture of the leak pathways from the ducts emerged (as judged through analysis of the data using the C-Tech Environmental Visualization System (EVS) software). Samples were taken on February $16^{\text {th }}$ and the injection of tracers was turned off. Samples were again taken to follow the decay and were collected on February $20^{\text {th }}, 22^{\text {nd }}$, and $28^{\text {th }}$. Past February $9^{\text {th }}$ samples were no longer taken from the canal deep pit as the area was marked as a contamination zone as part of a different characterization project. The data prior to the $10^{\text {th }}$ indicated that it was not worth the additional effort or worker exposure to continue sampling the canal deep pit. 


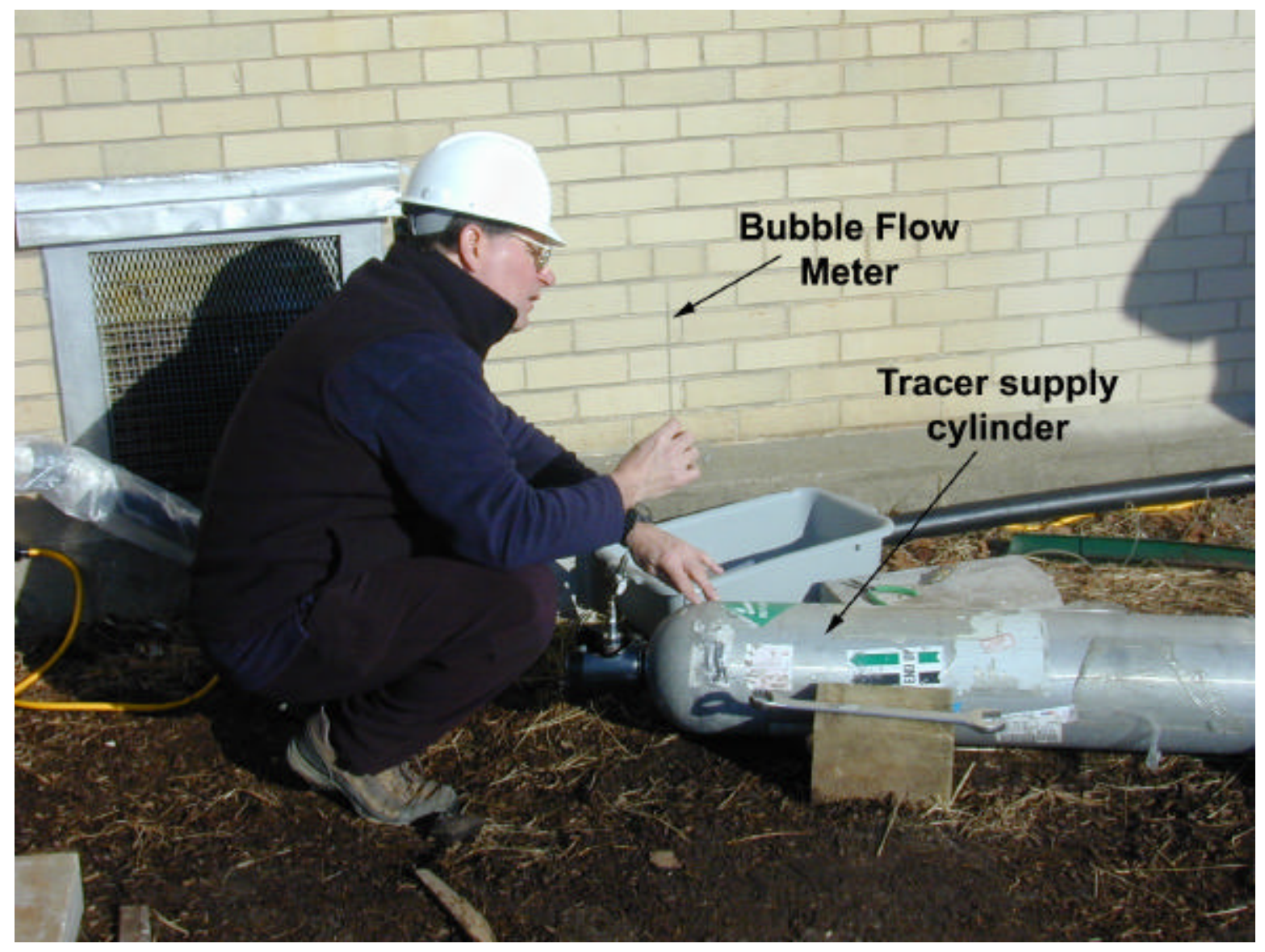

Figure 12. Measurement of tracer flow rate using a bubble meter

The external port sampling procedure had the following steps for each port;

- Attach a small air sampling pump (approximately two liters per minute capacity)

- Purge for 15 to 30 seconds

- Attach pump outlet to sampling bag and open valve on bag

- Pump approximately 0.5 to 1 liter of air into a sampling bag with a positive seal

- Close valve on bag and remove from pump outlet

- In a logbook, document the location (well number and port number), time of sample collection, date and any unusual difficulties in taking the sample

Weather affected the sampling to a small degree. There were several days of rain, snow, or snowmelt that caused localized flooding of some ports. Locations 31 and 34, along the top of the ducts, were consistently flooded, as evidenced by water being pumped out of the ports. Locations 8 and 19 had sporadic flooding of the top two ports. Pumping water into the lines led to the addition of water and particulate traps to the pumps. The water washed dirt into the pumps and damaged the Teflon valves allowing the inlet and outlet to backflow and decreased flow capacity of the pumps. This resulted in several port locations being declared "un-useable" or "difficult to sample" on that day by the technicians taking the samples. The technicians assumed the port was plugged, not that the pump had slowed down or stopped pumping. Daily flow checks of the pumps discovered the damaged valves. Once the traps were added (February 9) no further problems with the pumps occurred. This problem mainly affected data collection on February 9 and was reflected in the increased data loss of 28 percent for that day. 


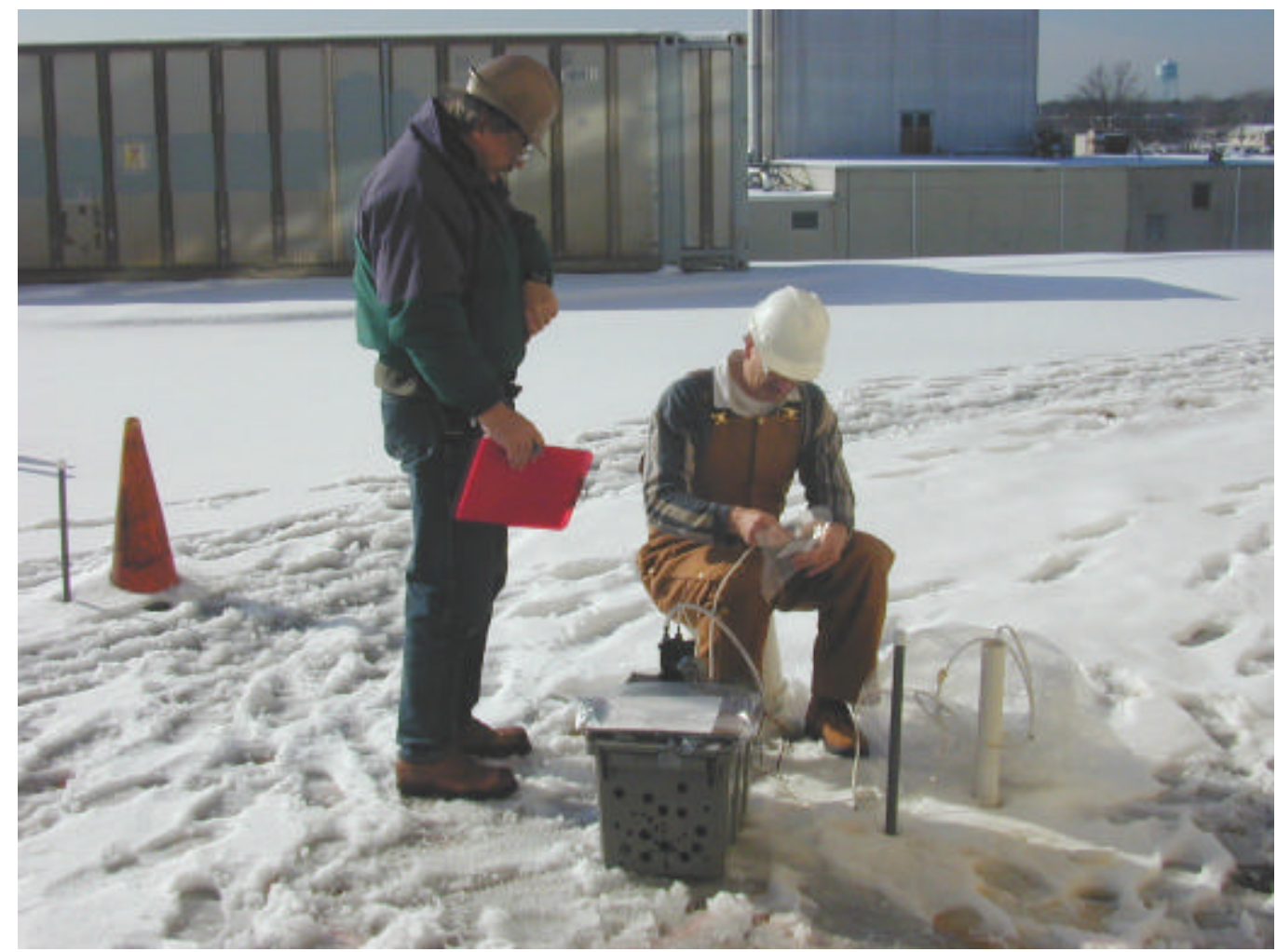

Figure 13. Collecting air samples from an external port

Several other ports had problems pulling samples; these may have been damaged during installation or had problems associated with high saturation of the soil around the ports. Ports that consistently had problems sampling included: 4S, 8-1, 8-2, 8-4, 17-2, 20-4, 21-1, 21-2, and 21-4. There were also 11 bag failures where the gas sample bags did not hold the sample while it was stored awaiting analysis. On average (excluding February $9^{\text {th }}$ ) data loss was seven percent each day, with the worst day after the traps were added being 14 percent. Problem ports accounted for six percent of the loss, the remaining losses (with the exception of data taken on February $9^{\text {th }}$ ) were attributed to sporadic flooding, nearly saturated soil surrounding the ports, or failed sample bags.

After sampling had been completed for any given day, the sampling bags were brought to an on-site analytical laboratory for chemical analysis. The PFTs were measured using a capillary adsorbent tracer sampler (CATS) which is a small cigarette-sized glass tube containing a carbonaceous adsorbent for the PFTs. A small known volume ( 0.5 to 1 cubic centimeters [cc]) of air was withdrawn from the sampling bag using a syringe. The CATS was attached to a length of surgical tubing through which nitrogen gas is flowing. The air sample was injected into the tubing and carried through the CATS (Figure 13) where the PFT was adsorbed. The CATS was placed on a rack connected to a gas chromatograph (GC) (Figure 14) that was specifically designed to measure PFTs. The PFTs were thermally desorbed from the CATS and drawn into the GC. The GC readings were converted into PFT concentrations. The technician performing the analysis documented the measured PFT concentration, CATS identifier, and sample location. After analysis, the CATS were baked to remove any residual PFTs to ready them for re-use. Sample bags required cleaning by flushing three times with nitrogen prior to reuse.

During the leak test, the concentration of tracers in the internals remained at reasonable levels. PMCP levels averaged $160 \mathrm{ppb}$ in the south secondary duct over the nine-day injection period. In the north 
secondary duct, PMCP averaged 213 ppb over the three days of injection. Levels in the north duct fell continuously once the mis-labeled cylinder was replaced. The o-PDCH concentrations averaged $6.5 \mathrm{ppb}$ in the north secondary duct and $0.08 \mathrm{ppb}$ in the south secondary duct.

Cross contamination/dilution effects from the primary ducts, reactor pile, canal deep pit, and intake manifold continued to be low. Average PMCP levels were $4 \mathrm{ppb}$ in the south primary duct, $4 \mathrm{ppb}$ in the north primary duct, $1 \mathrm{ppb}$ in the reactor pile and $1.1 \mathrm{ppb}$ in the canal deep pit. For o $\mathrm{PDCH}$ average levels were $0.8 \mathrm{ppb}$ in the north primary duct, $0.4 \mathrm{ppb}$ in the south primary duct, $0.2 \mathrm{ppb}$ in the reactor pile, and not sampled for in the canal deep pit.

The PFT concentrations from the external and internal sampling ports are listed in the data sheets in Appendix A and discussed in the results and conclusions sections.

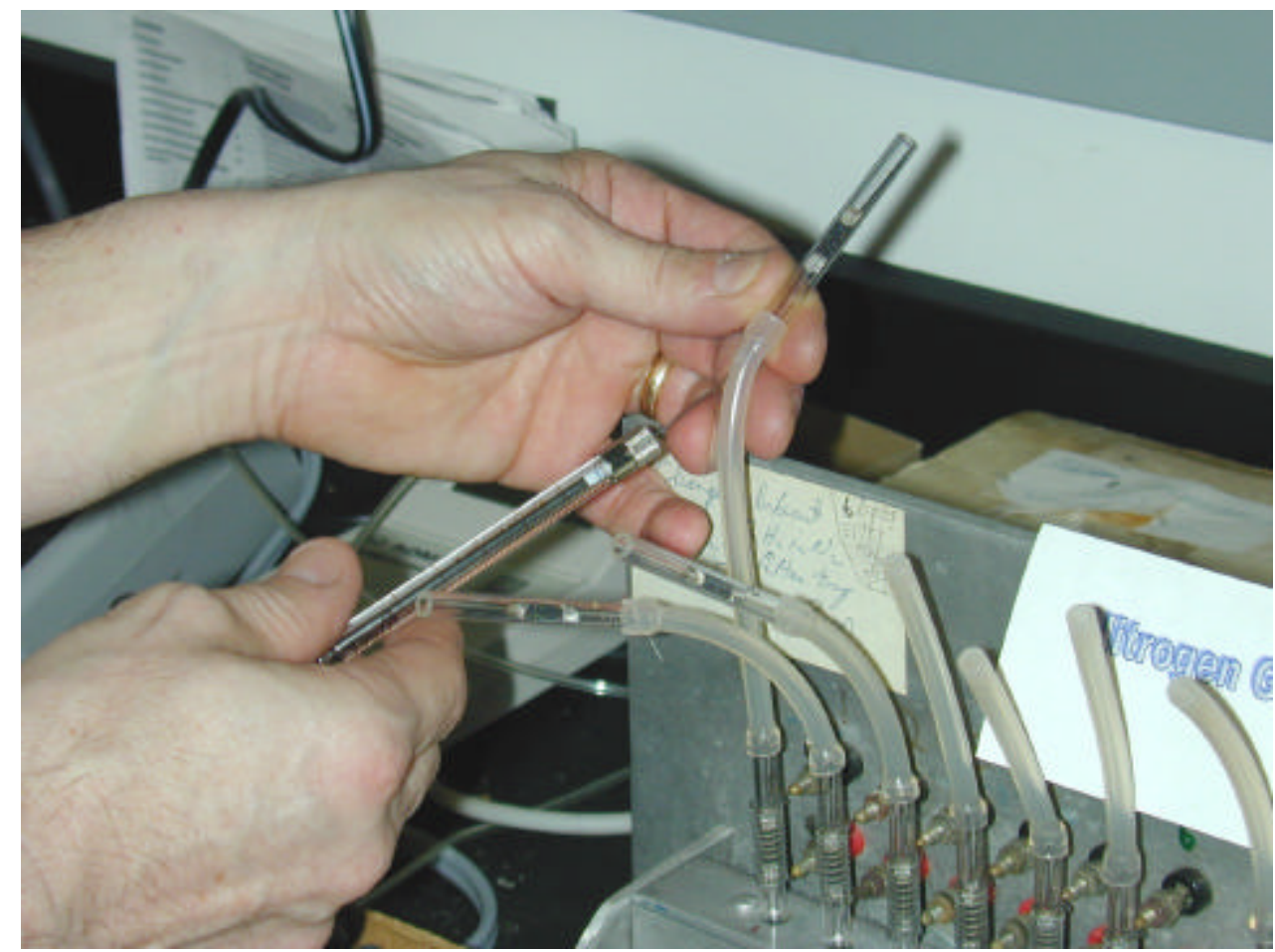

Figure 14. Injection of sample onto a Capillary Adsorbent Tracer Sampler (CATS)

\section{DATA INTERPRETATION}

The BGRR below grade ducts were constructed with five major expansion joints. Figure 16, South duct features, and 17, North duct features, are side view representations of the ducts indicating the location of the expansion joints in these ducts. Additionally, each bustle area labeled on the figures has an expansion joint. It was expected that the expansion joints would be susceptible to gas leakage due to corrosion from water accumulated in the ducts in the years since the BGRR was shut down. The accumulated water was pumped out in 1998, and the area has been monitored for water intrusion since. These figures also include the approximate location of the high water marks found inside the duct. At the lowest elevation, near Building 701, the water mark was approximately 66 inches above the bottom of the primary duct. Therefore, gas leak pathways below the high water level required increased attention as they may be indicative of water leak pathways. 


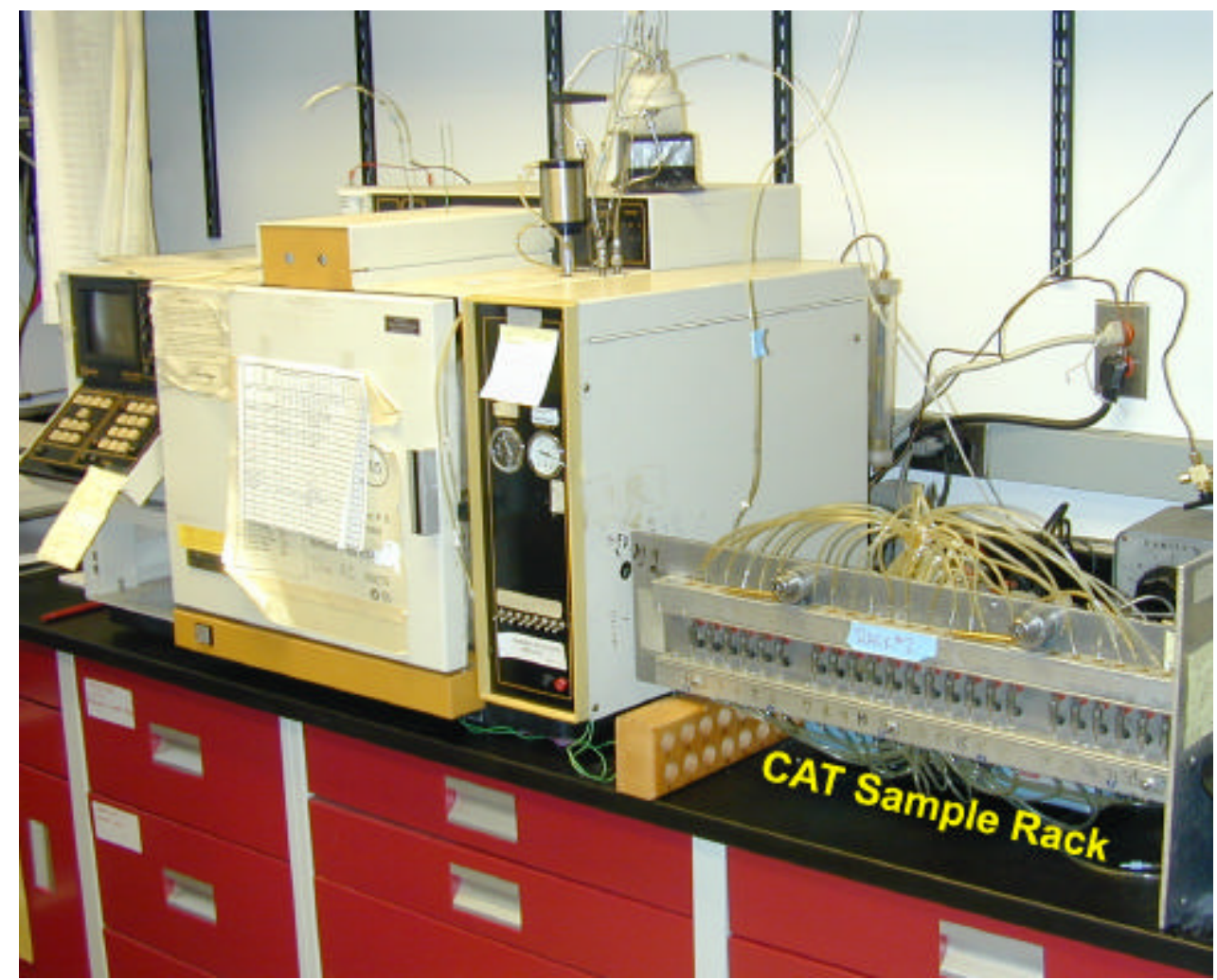

Figure 15. Gas chromatograph and CATS sample rack used to analyze samples for PFTs

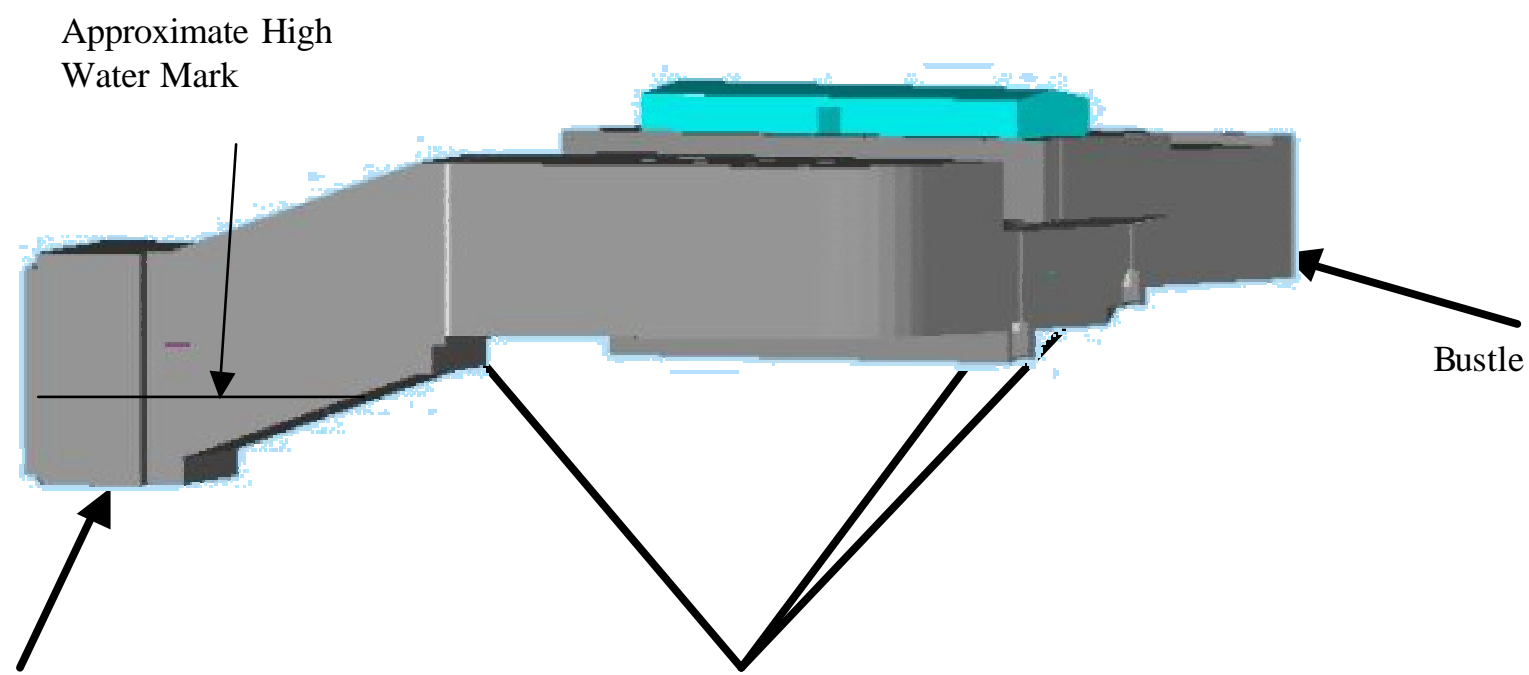

Bustle

Expansion Joints

Figure 16. South duct features 
As discussed previously, two PFT tests were conducted to define potential water leak pathways from the below grade ducts. In the first test, the intent was to estimate the PFT loss rate from the secondary plenum to the primary plenum and volume beneath the BGRR pile. The tracer $\mathrm{PMCH}$ was injected into the south duct and PDCB was injected into the north duct from January 30 through February 6 . This information was used to define PFT injection rates for the second test.

In the second test, PMCP was injected into the south duct from February 7 through February 16. Due to a labeling error on the gas cylinder, PMCP was also injected in the north duct from February 7 through February 9. The error was detected on February 9 and a different gas cylinder containing o-PDCH was used for the north duct until February $16^{\text {th }}$. In the second test, soil gas samples were collected from 131 exterior monitoring ports on February $6^{\text {th }}$ to obtain a baseline for the two tracers, PMCH and PDCB, used in the first test. On February $8^{\text {th }}$ samples were collected from all bottom port locations. Starting February

\section{Expansion Joints}

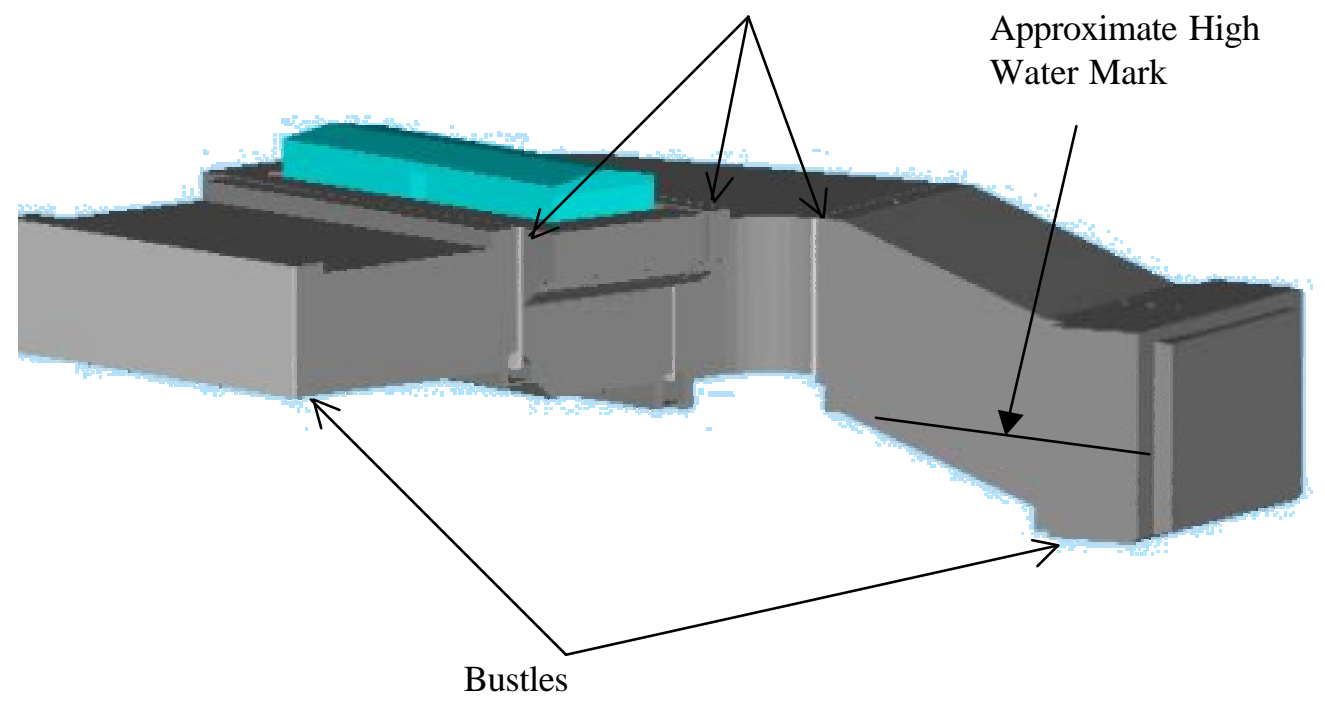

\section{Figure 17. North duct features}

$9^{\text {th }}$ complete sampling of the interior and exterior ports was initiated. Samples were collected on February $9^{\text {th }}, 10^{\text {th }}, 12^{\text {th }}, 14^{\text {th }}, 16^{\text {th }}, 20^{\text {th }}, 22^{\text {nd }}$, and $28^{\text {th }}$. The data were evaluated to determine potential leak pathways.

It was not possible to locate sample ports directly underneath the ducts. Therefore, to obtain information on potential leaks from underneath the ducts, two approaches were used. First, the bottom sampling port from each monitoring location was placed at an elevation approximately one foot below the exterior of the duct. The duct was constructed with approximately 2'10" of concrete on the bottom. Thus, the secondary plenum was approximately $3-4$ feet above the lowest sampling port. Therefore, leaks in the bottom would show up first at these bottom sampling ports. Second, the time-evolution of PFT concentrations was followed after the source to the ducts was stopped. If the PFT concentration peaked after the tracer injection was stopped and remained relatively constant for several days, this indicated the 
leak location was a large distance from the measurement point. By comparing concentrations at adjacent ports and following their time histories, evidence of bottom leaks was obtained.

The data interpretation section of this report is divided into two major sections. One section covers the internal monitoring ports for the preliminary and leak tests. The other section covers the external monitoring ports for the leak test.

\section{Internal Monitoring}

\section{Preliminary Test}

From January 30, 2001 through February 6, 2001, the PFT PDCB was injected into the north duct and PMCP in the south duct. During this period internal samples were collected at two locations in each duct to follow the buildup of PFT concentration in the secondary plenum. In addition, concentrations were measured in the primary plenum of each duct and beneath the reactor pile. After a few days, the concentrations remained stable indicating losses due to leakage were balanced by injection.

Figure 18 presents the concentrations at the two monitoring locations (SLIP - South Loop Injection Point and SDBTC - South Duct Bottom Tracer Concentration) in the secondary plenum during the entire testing period (interior sampling locations are provided in Figure 1). Figure 18 demonstrates the excellent agreement between the two locations indicating that the tracer was well mixed in the plenum.

Comparison between SLIP and SDBTC for

Tracers Injected in the South Duct (PMCH)

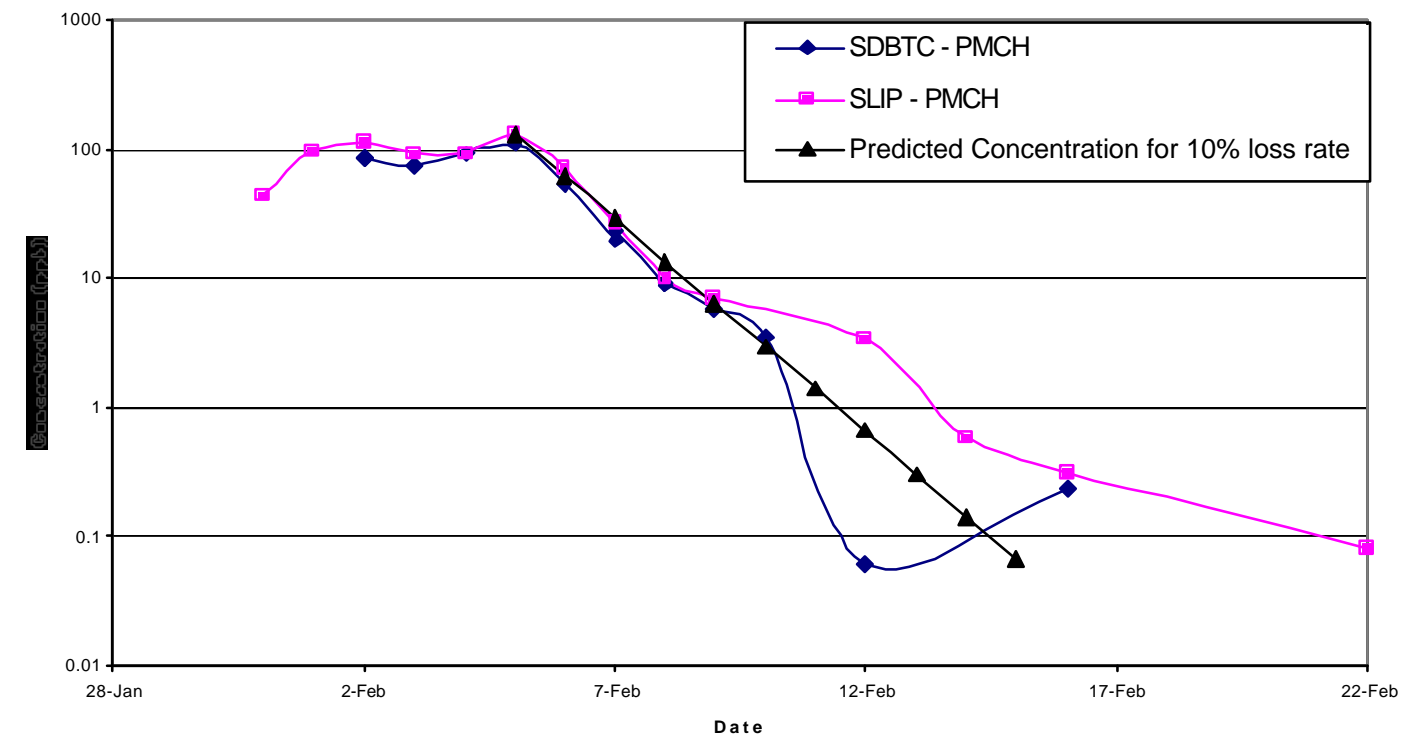

Figure 18. PMCH Concentration in the south duct secondary plenum 
An equilibrium concentration of approximately $100 \mathrm{ppb}$ was maintained during the injection period. Once the injection was stopped on February $6^{\text {th }}$, the concentrations both decreased at a steady rate. By performing a simple mass balance model, it was estimated that approximately 10 percent of the tracer was lost for each complete volume circulation for the south duct secondary plenum. In this duct, the flow rate of ten cubic feet per minute led to a complete exchange of the air volume of the secondary plenum in approximately 3.3 hours. The model, assuming a 10 percent loss rate per complete air exchange, predicted an equilibrium concentration of approximately $100 \mathrm{ppb}$ for the injection concentration and flow rate used in the test.

Comparison of NLIP and NDBTC for PDCB tracer injected in the North Duct

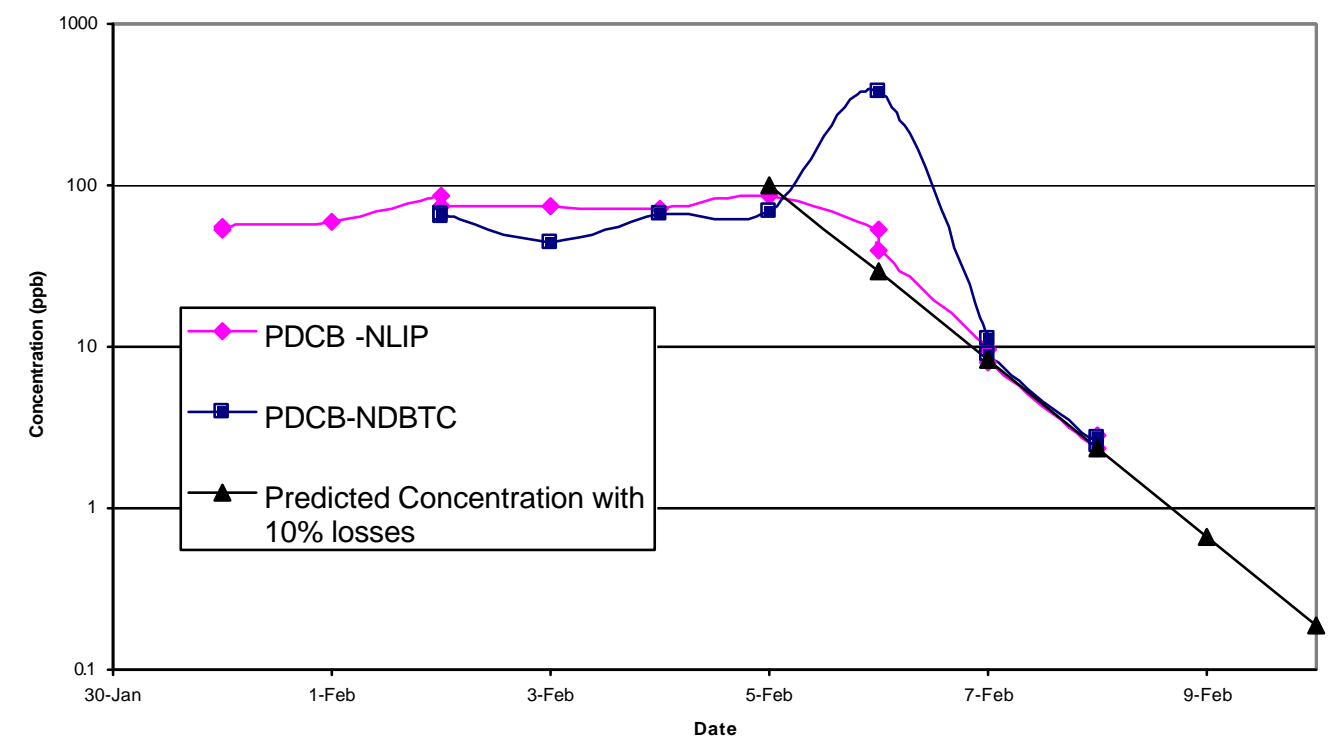

Figure 19. PDCB Concentration in the north duct secondary plenum

Figure 19 displays the PDCB concentrations in the north duct. Again, an equilibrium concentration near $70 \mathrm{ppb}$ was attained during the injection period. The peak in concentration was observed on February $6^{\text {th }}$ at the end of the injection period. This is believed to be due to experimental error due to insufficient purging of the sample lines. However, this cannot be unequivocally demonstrated. Figure 19 contains the concentrations at NLIP (North Loop Injection Point), NDBTC (North Duct Bottom Tracer Concentration), and the predicted concentration after the source was turned off, assuming ten percent loss for each time the volume of flow induced by the fan equaled the volume of the secondary plenum. The north duct is approximately 40 percent smaller than the south duct in volume and, a complete exchange of air through the plenum required only 2 hours. Therefore, the decay in concentration was expected to occur much faster than in the south duct. This was the case, and the predicted curve matched the data well for the first three days after the source was terminated. After February $9^{\text {th }}$, the measured value of PDCB in the two sampling locations was less than $0.001 \mathrm{ppb}$. The cause for the rapid decrease in PDCB concentration after this time is not known. 


\section{Leak Test}

The leak test was started on February $7^{\text {th }}$ with the tracer PMCP in the south duct and February $9^{\text {h }}$ with the tracer o-PDCH in the North Duct. Internal concentrations did not match as well as in the preliminary test. In general, the measured values at the points designated as bottom tracer (NDBTC and SDBTC) were a factor of five less than the values measured at the injection points (NLIP and SLIP). At the south injection point (SLIP), the PMCP concentration averaged approximately $100 \mathrm{ppb}$ during the injection period. At the north injection point (NLIP), the o-PDCH concentration averaged approximately $6.5 \mathrm{ppb}$. The lower concentration of o-PDCH was expected because of a lower injection concentration. As discussed earlier, this source was placed into service on February $9^{\text {h }}$ after the discovery that the tracer injected into the north duct was PMCP instead of oPDCH due to a labeling error. The need to replace the mislabeled source as soon as possible did not allow time to adjust the flow rate (by fabricating a new restrictor) to reach $100 \mathrm{ppb}$ internal concentration. Based on data from February $6^{\text {th }}$, it was clear that a 6.5 ppb internal concentration would lead to sufficient concentrations in the soil to accurately define leak pathways.

\section{Cross-Talk}

Both ducts connect to the graphite pile. Thus, the gases could mix here and cross contamination could occur. Another area where cross contamination might also exist is the expansion joints if corrosion has resulted in interconnectivity. To examine this effect, the concentrations of tracers injected in the north duct were measured in the south duct and vice versa. Table II presents the average concentrations of the tracers in the north and south secondary plenum near the injection point (NLIP and SLIP) during the injection periods.

Table II: Comparison of tracer concentrations in the secondary plenum

\begin{tabular}{|c|c|l|l|l|}
\hline Tracer & Injection Duct & $\begin{array}{l}\text { Average } \\
\text { Concentration in } \\
\text { Injection Plenum, } \\
\text { ppb }\end{array}$ & $\begin{array}{l}\text { Average } \\
\text { Concentration in } \\
\text { Opposite Plenum, } \\
\mathrm{ppb}\end{array}$ & $\begin{array}{l}\text { Ratio } \\
\text { (Injection/Opposite) }\end{array}$ \\
\hline PDCB & North & 71 & 0.7 & 101 \\
\hline PMCH & South & 108 & 9.9 & 11 \\
\hline o-PDCH & North & 6.5 & 0.084 & 77 \\
\hline
\end{tabular}

From Table II it is clear that there is a substantial transfer from the south plenum to the north plenum as evidenced by the lower ratio value for $\mathrm{PMCH}$, which was injected in the south. The ratio for PMCH was 11, indicating 11 times as much tracer in the south secondary plenum where it was injected as compared to the north plenum. The transfer of tracers injected into the north plenum to the south plenum was not as substantial. For the two tracers injected into the north secondary plenum, they appeared in the south plenum at approximately one percent of the value in the plenum to which they were injected. The tracer PMCP was inadvertently injected into both ducts and therefore could not be relied upon to determine cross communication between ducts. However, by February $16^{\text {th }}, 6$ days after the injection of PMCP into the north duct was stopped, the north plenum PMCP concentration was approximately $1 / 10$ the value found in the south plenum where it was still being injected. This is higher than would be expected from dilution as shown in the preliminary test and is consistent with the cross-talk ratio obtained from PMCH. 


\section{Leak Detection - External Monitoring}

Figure 20 presents a top and side view of the sample locations and individual port locations for the south duct and a side view of the north duct. Due to the perspective it is necessary to look at both views to accurately locate a sampling port. The figure also contains the sample location identifier, which are numbered from 1-42. Sample locations 1-15 and 42 are on the south duct. Sample locations 16-25 are on the north duct. Port locations $26-41$ are along the top of the ducts. The port locations are used in the discussion of the data analysis. On the south duct, sample location 1 is at the expansion joint within the bustle near building 701. Sample location 4 is at the first expansion joint. Sample location 11 is at the expansion joint at the front of the filter bed area and location 13 is at the expansion joint at the back of the filter bed area. Sample location 42 is at the expansion joint near the instrument house (not shown). The blue spheres at different elevations along the images for the south and north ducts represent the exact location of the sampling port. On the north duct, sample location 16 is at the expansion joint in the buste near building 701. Sample location 19 is located at the first expansion joint. Due to obstructions, Sample location 20 could not be located directly on the expansion joint at the front of the filter bed region. It is located approximately four feet from location 19 and six feet from the expansion joint. Location 21 is approximately ten feet past the expansion joint, in the middle of the filter bed region. Location 22 is at the expansion joint at the far end of the filter bed. Location 25 is at the expansion joint near the instrument house.

\section{Sampling Port Locations and Data Interpretation}

The design objective for installing sampling ports along the sides of the ducts was to locate the deepest port just below the bottom of the exterior of the duct. Ports were placed every five feet to reach the top of the duct. The duct has a 2'10" concrete base on which the plenum rests. Therefore, the primary plenum is approximately three feet above the bottom of the duct exterior. Thus, the second port from the bottom is located two feet above the bottom of the plenum. The third port is located approximately seven feet above the bottom of the plenum. This is approximately the midpoint of the plenum. The next port was located two feet from the top of the plenum and the top port was located just above the top of the exterior of the duct. Each sampling port was given a location and a depth identifier. For example port 2-4 is location 2, depth 4 . The depth identifiers are 4 for the deepest port, 3 for the port near the bottom of the plenum, 2 for the port near the midpoint of the plenum, 1 for the port near the top of the plenum, and S (shallow) for the port above the top of the duct. For sampling ports above the top of the duct (location identifier 26-41), the depth identifier was 1 . The building at the surface is the roof over the filter bed region.

\footnotetext{
Interpretation of Color Contour Figures

In all of the figures containing concentration contours along a duct, the regions of the highest concentrations are denoted in red and indicate large leaks, the lowest concentrations are in blue and indicate regions without leaks. The color scale is logarithmic, the peak value is the maximum observed value in the soil along the duct at any time during the test for the tracer under consideration. Measured values within an order of magnitude of the peak appear in red, orange, or yellow. Measured values between one and two orders of magnitude less than the peak value are in green. Measured values more than two orders of magnitude less than the peak value are in blue. The concentration value is representative of the amount of mass transfer from the secondary plenum to the air in the surrounding soil and provides a rough estimate of the magnitude of the size of the leak. Thus, an area indicated in green would have a leak size that is one to two orders of magnitude less than the maximum leak size. Although the values on the color key will change for each tracer, this color scheme is consistently used for all of the following depictions of gas leakage.
} 
Sampling Ports

Top View

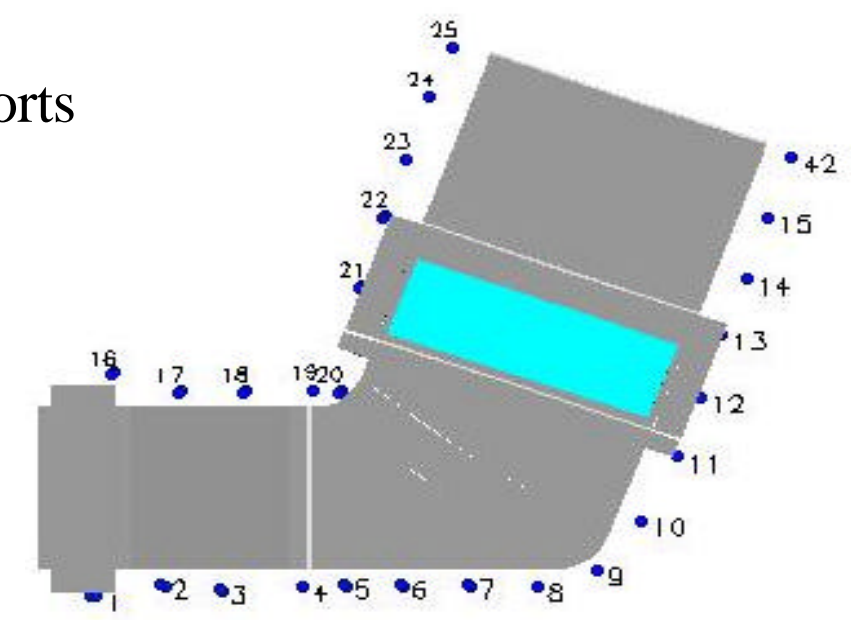

\section{South Duct Sampling Ports}

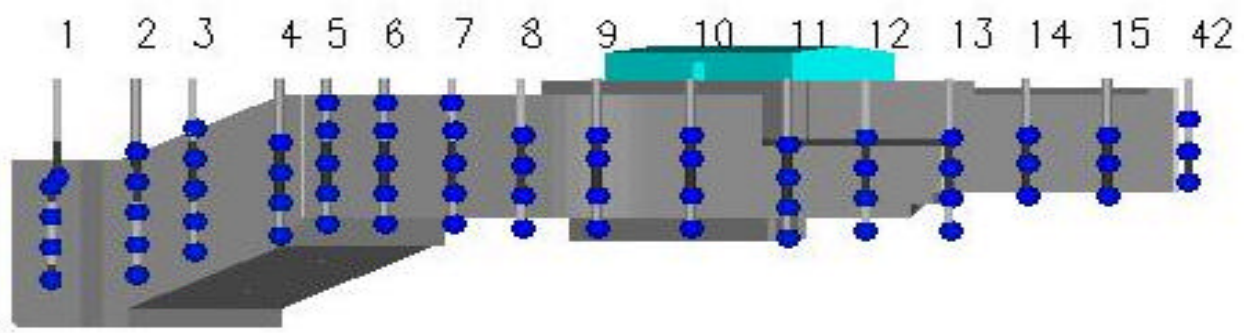

North Duct Sampling Ports

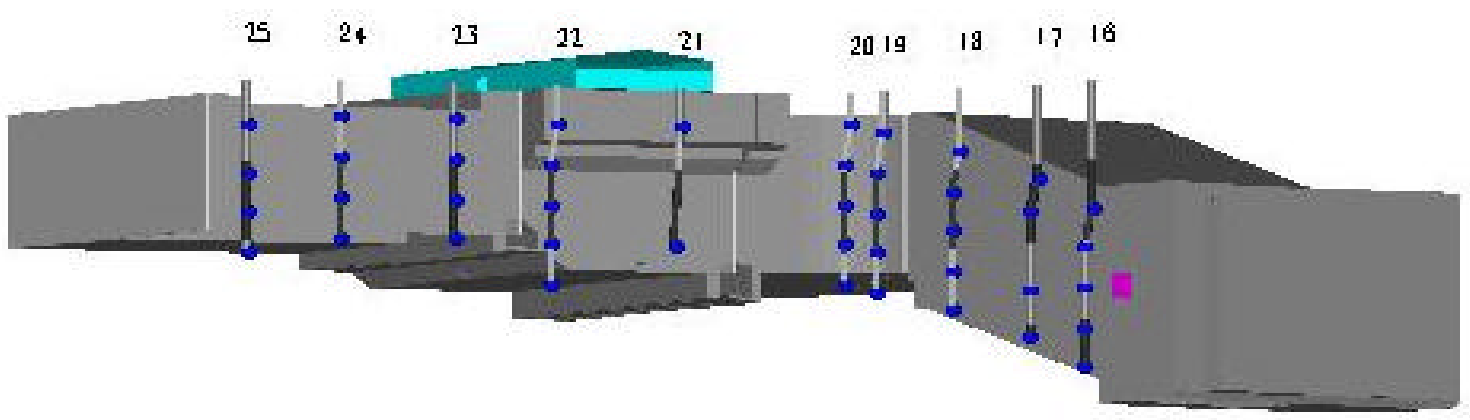

Figure 20. Top and side view of sample locations 


\section{Leaks Along the Sides of the Ducts}

\section{South Duct}

PMCH was injected into the south duct from January $30^{\text {th }}$, through February $6^{\text {th }}$. A complete set of exterior samples was collected on February $6^{\text {th }}$. Figure 21 displays the concentration profile for PMCH along the south duct on February $6^{\text {th }}$. The figure contains all measured sampling ports (small colored circles) and provides a concentration contour along the duct. This profile is a fully developed profile as it represents the concentrations at the end of the injection period. Sampling ports above the duct are visible and color-coded to the same scale. Viewing Figure 21, it is clear that the greatest leaks all occur along the expansion joints. The largest leak occurred at the first bustle (see Figure 16 for bustle and expansion joint locations and Figure 20 for port locations)and the peak measured value was $82 \mathrm{ppb}$. Considering that the concentrations PMCH in the south secondary plenum were approximately $100 \mathrm{ppb}$, further supports the notion that there is a large leak at this location. The second largest leak occurs at the second expansion joint $\left(4^{\text {th }}\right.$ set of sampling ports, port 43$)$. It has a concentration approximately half the value of the largest leak. Smaller potential leaks are found at the locations of the other expansion joints. These leaks are one-tenth to $1 / 100$ of the size of the largest leak. Large areas of this duct are not leaking gas as evidenced by the blue regions.

\section{PMCH South Duct View February 6, 2001}
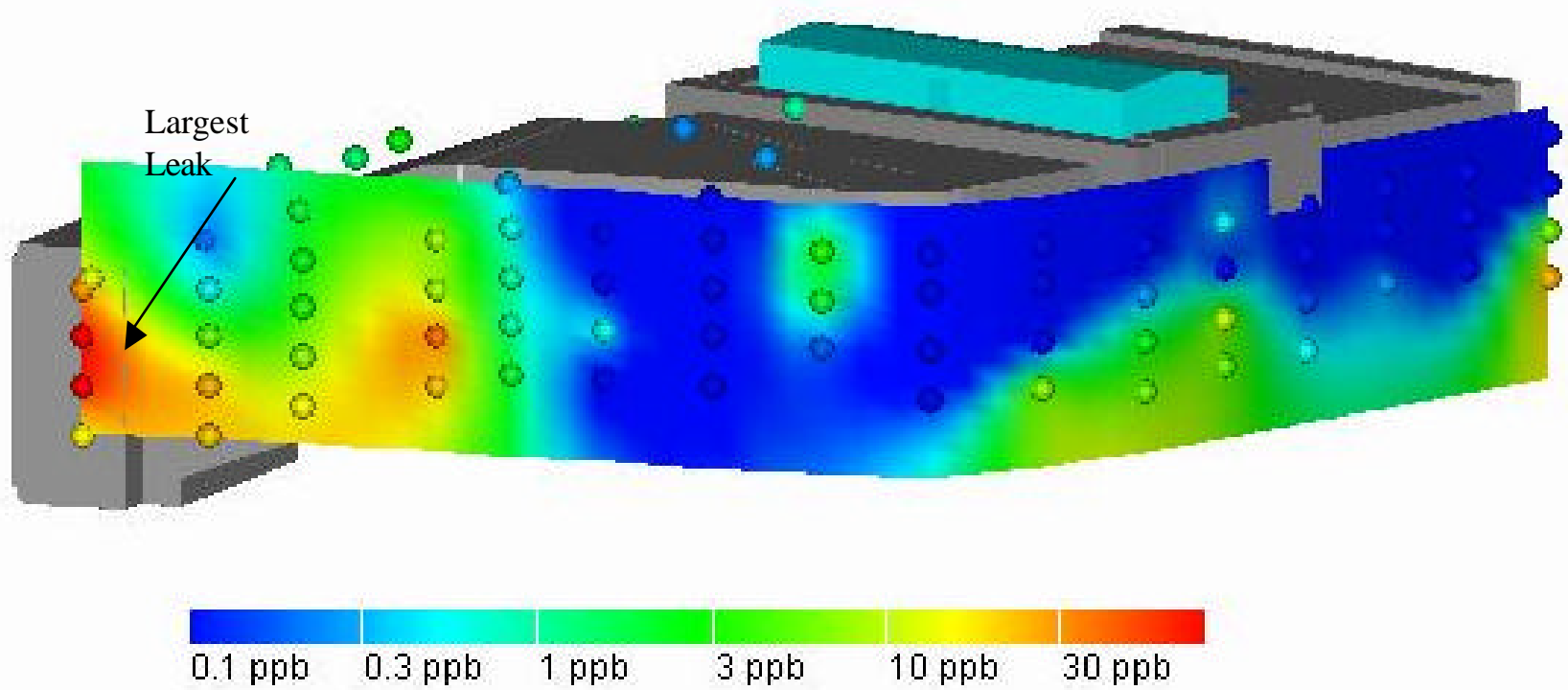

Figure 21. PMCH concentration contours the day after completion of the sevenday injection period 
In the leak test, PMCP was injected in the south duct from February $7^{\text {th }}$ through the $16^{\text {th }}$. Figures 22,23 , and 24 show the buildup and decline of PMCP along the south wall from February $9^{\text {h }}$ through February $22^{\text {nd }}$.

\section{PMCP South Duct View February 9,2001}

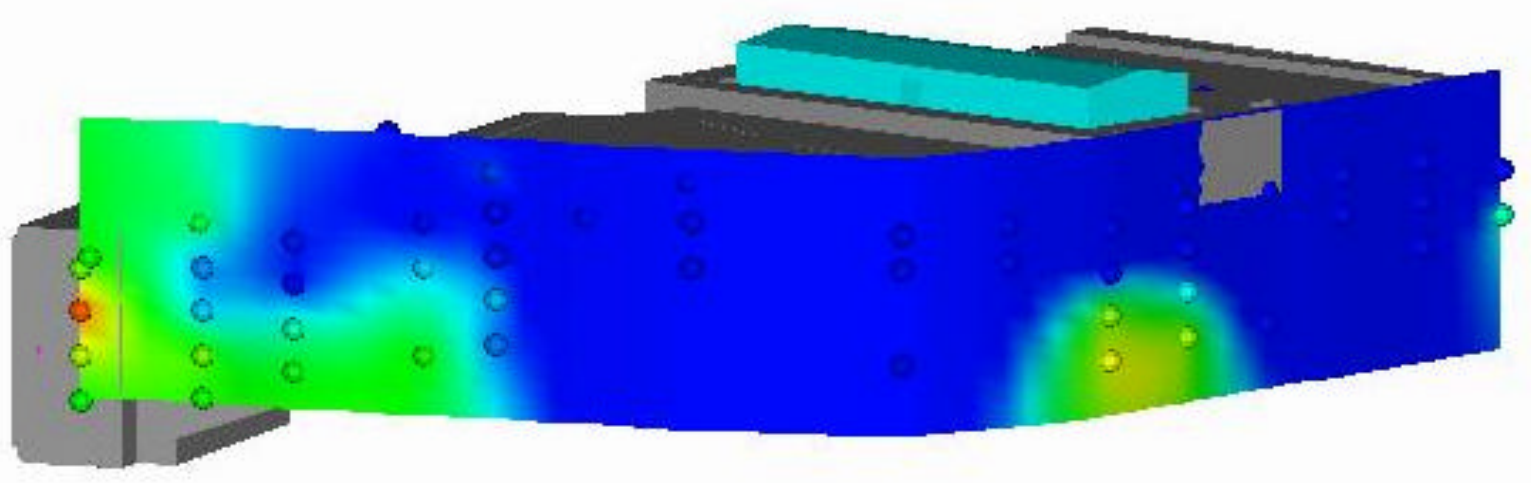

\section{PMCP South Duct View February 10, 2001}

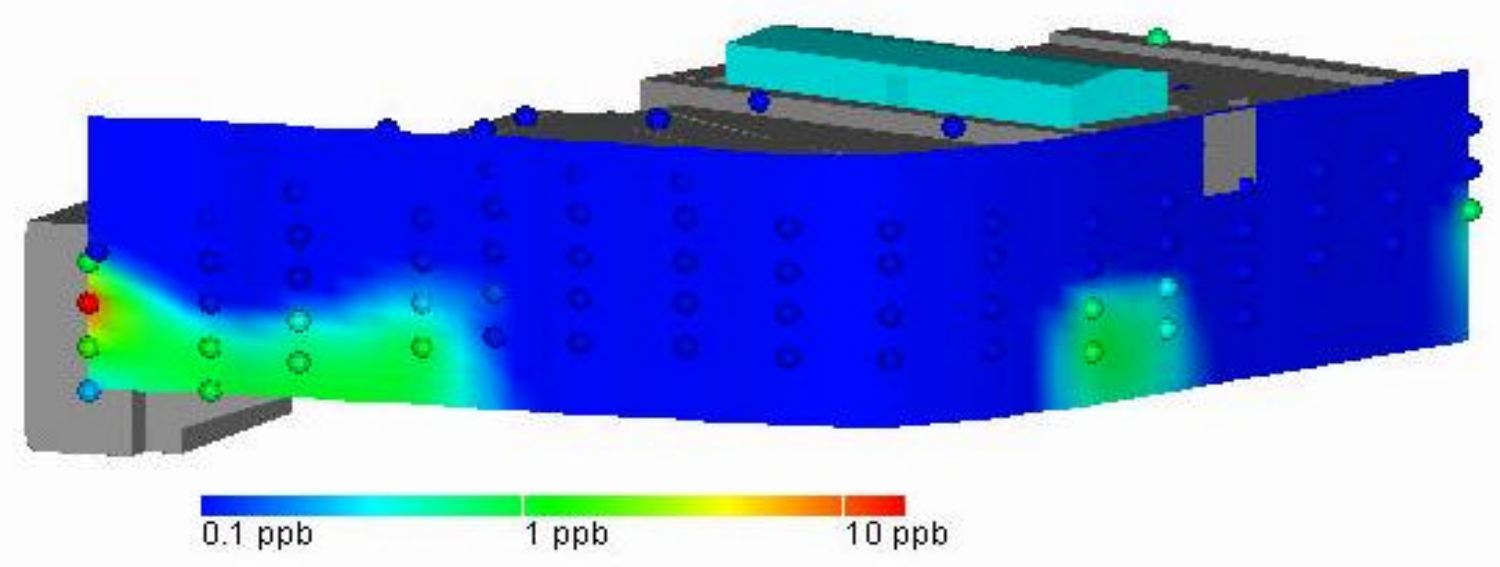

Figure 22. PMCP concentrations on the second and third day after the leak test injections were started 


\section{PMCP South Duct View February 12, 2001}

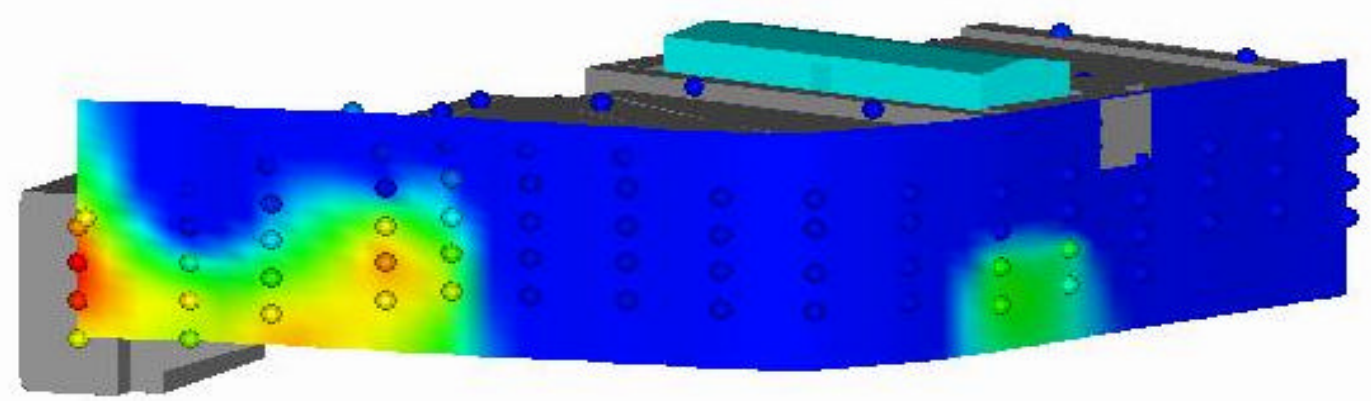

February 14, 2001
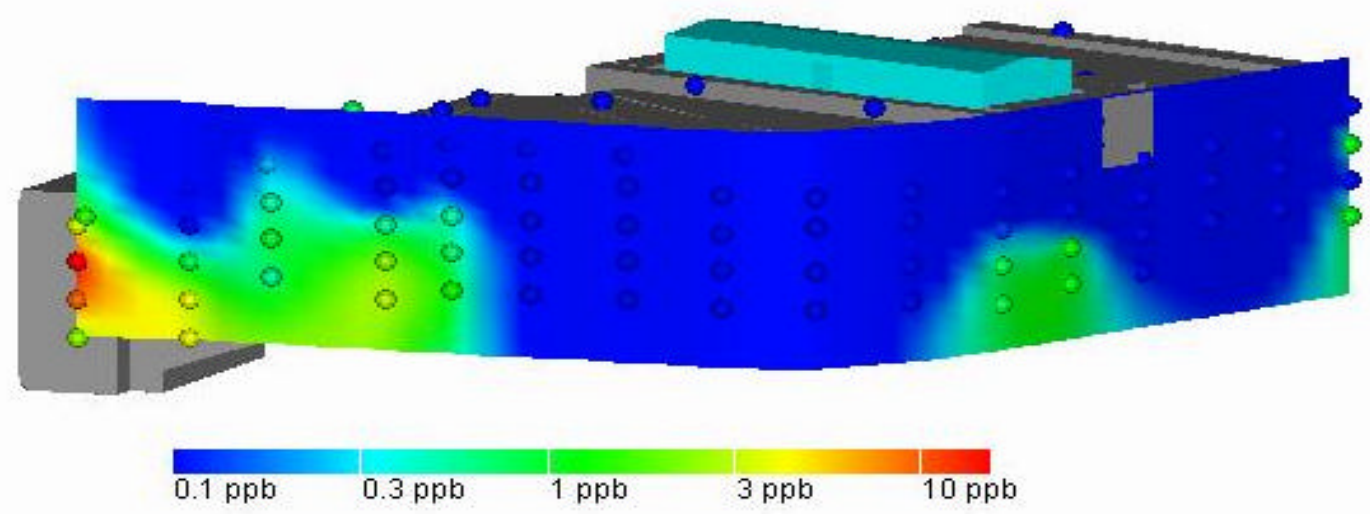

\section{February 16, 2001}

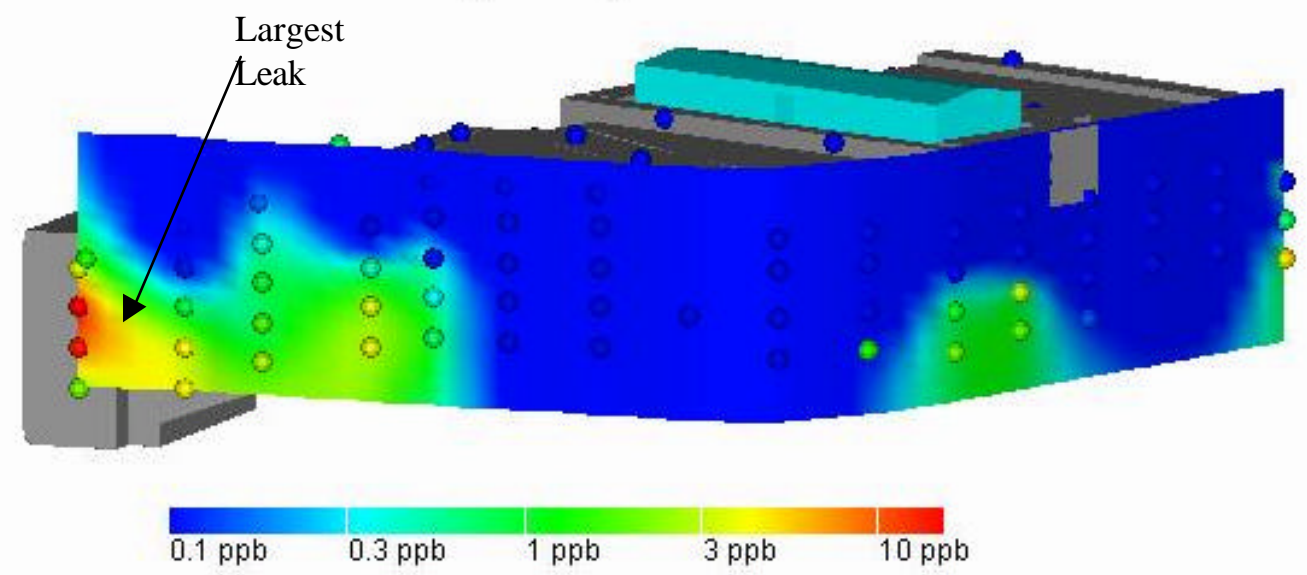

Figure 23. PMCP concentration on the fifth, seventh, and ninth day after the leak test was started 


\section{PMCP South Duct View February 20, 2001}

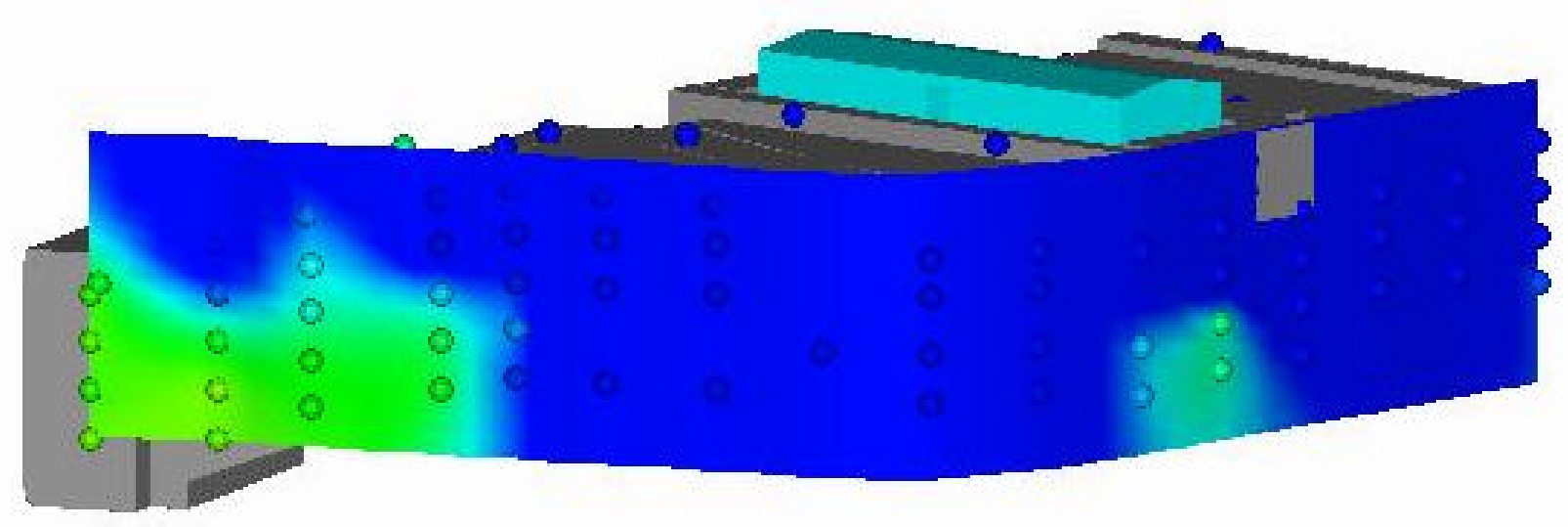

\section{February 22, 2001}

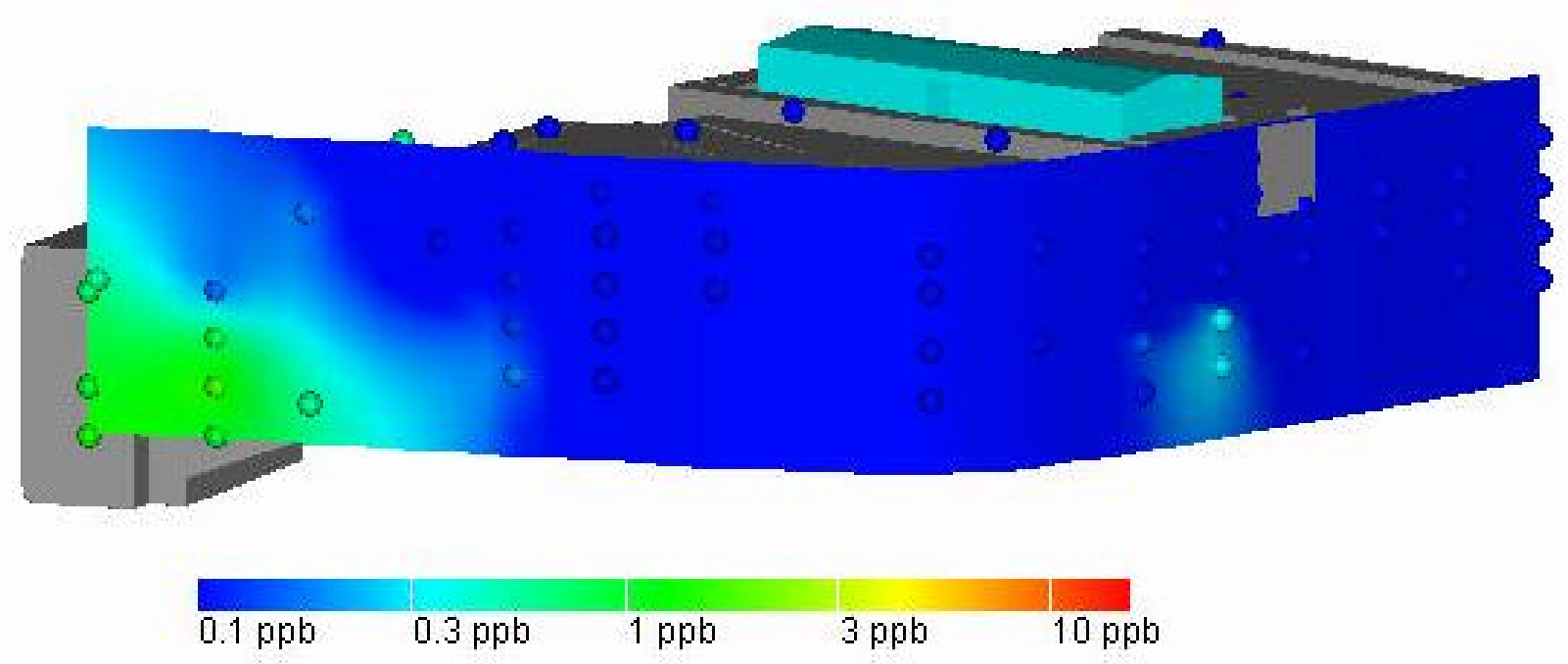

Figure 24. PMCP concentrations on the fourth and sixth days after injection was completed 
The leak at the first bustle is seen to appear on February $9^{\text {h }}$, the first sampling date after the injection was started. The concentration of PMCP at this location (1-2) continues to increase until February $12^{\text {th }}$, after which time it remains stable at around $15 \mathrm{ppb}$. This is the largest leak on this side. The sampling port immediately beneath this port (1-3) also has high measured PMCP concentrations. This indicates the leak is between the two sampling ports. The fact that the concentration in the lower port was slightly less than port 1-2 on the $9^{\text {th }}$ and $10^{\text {th }}$ indicates that the leak is probably closer to port 1-2. It is interesting to note that the observed high water line in the primary plenum is located between ports 1-2 and 1-3. The second biggest leak was found at the first expansion joint (4th set of sampling ports). Potential leaks were also found near the expansion joint at the filter bed area. (11-4). A possible leak in the bottom of the duct can be seen at the bustle area near the instrument house (42-4, far edge of the figure). At this location, PMCH did not arrive until February $14^{\text {th }}$ indicating that potential leak was along the bottom of the south duct several feet away from the sampling port (i.e. near the middle of the plenum). The possibility of bottom leaks will be discussed later in this report.

The leak profile is remarkably stable during the injection test providing confidence that the information provided by the test is reliable. In addition, the leak profile of PMCP (second test) is similar to that found by PMCH (first test). This provides further confidence that all leak pathways from the south plenum to the surrounding soils have been defined. Similar graphical visualizations were generated for all tracers on all sampling dates. Examination of the concentration profiles for all tracers including those injected into the north duct (PDCB and o-PDCH) all showed the same leak locations. The appearance of tracers injected in the north duct outside the south duct will be discussed later in this report.

\section{North Duct}

PDCB was injected into the north duct secondary plenum from January $30^{\text {th }}$, through February $6^{\text {th }} . A$ complete set of exterior samples was collected on February $6^{\text {th }}$. Figure 25 displays the concentration profile for PDCB along the north duct on February $6^{\text {th }}$. The figure contains all measured sampling ports (small colored circles) and provides a concentration contour along the duct. This profile is a fully developed profile as it represents the concentrations at the end of the injection period. The last set of sampling ports on the south duct and the ports above the ducts are visible and color coded to the same scale. The same color scale was used as in the previous figures, red regions represent the areas of highest leakage, green regions indicate intermediate amounts of leakage (one to two orders of magnitude lower that the red regions, and blue regions indicate areas where leakage is not occurring. Comparing this figure to the leakage data presented for the south duct (Figures $21-24$ ), it is clear that there are larger areas of leakage on the north side. The largest leaks occurred at expansion joint on the northernmost side of the filter house (port 22-3, see Figure 17 for bustle and expansion joint locations) and the first bustle (left part of the figure, $1^{\text {st }}$ set of sampling ports, port 16-3). The measured values at these two locations were approximately 41 and $40 \mathrm{ppb}$, respectively. The concentrations PDCB in the north secondary plenum were approximately $100 \mathrm{ppb}$, indicating a relatively substantial leak at these locations. Both of these ports are located two to three feet above the bottom of the secondary plenum. The port at 16-3 is in the vicinity of the high water mark noted on Figure 17. Figure 25 indicates that there was widespread leakage. Approximately 25 percent of the sampling ports (12 of 46) have a measured value within a factor of two of the peak measured value and almost 50 percent (22 of 46) of the ports have a value within a factor of four of the peak measured value. Leakage is largest at the expansion joints, but it is also relatively substantial at other locations as evidenced by the wide distribution of leaks depicted in Figure 25. 


\section{PDCB North Duct View February 6, 2001}

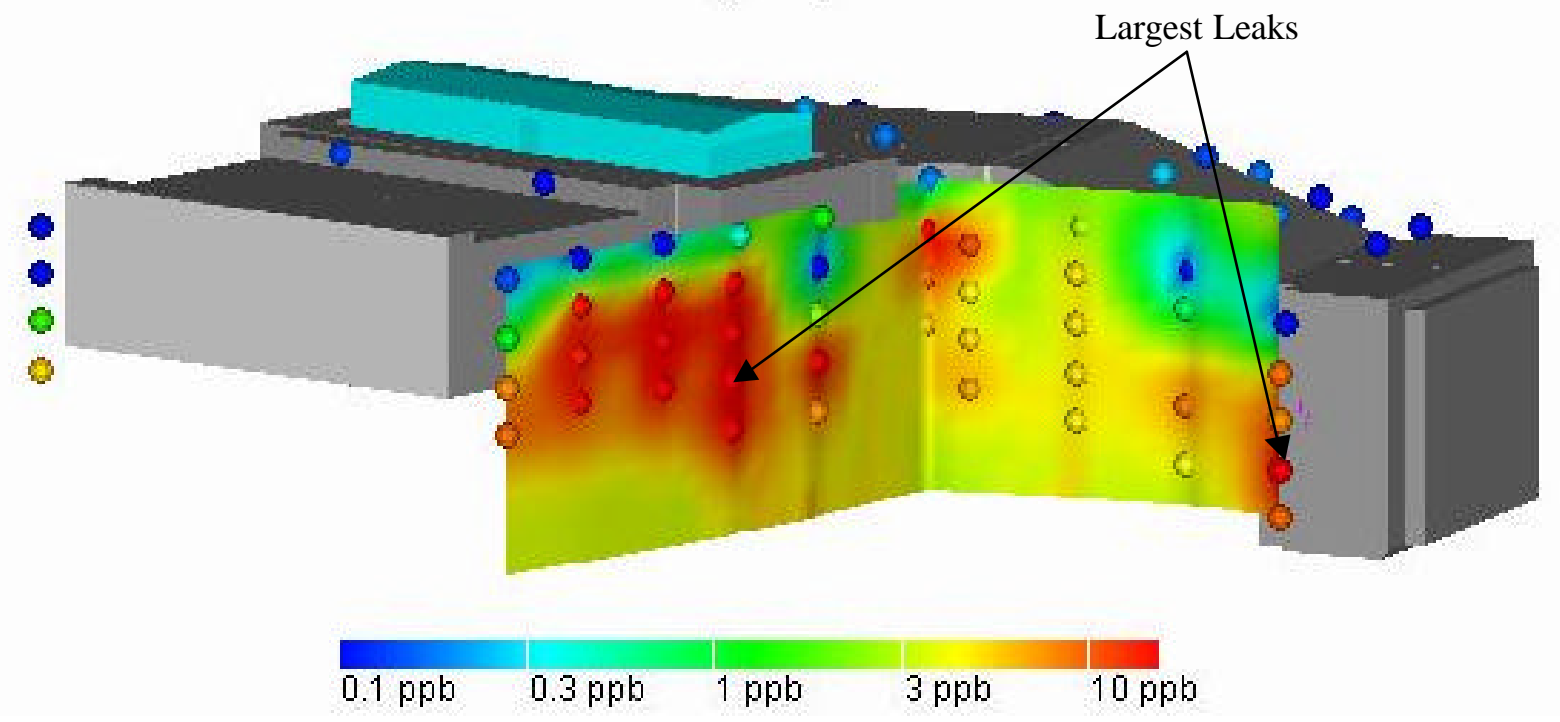

Figure 25. PDCB concentration contour at the end of the eight-day injection period, February 6th

During the leak test, o-PDCH was injected into the north duct secondary plenum from February 9 to February $16^{\text {th }}$. Figures 26 and 27 present the time evolution of o-PDCH concentration along the north Duct. From this time evolution further refinement in detecting the leaking areas can be obtained. The data from February $10^{\text {th }}$ were collected in the morning, approximately 16 hours after the start of injection. There is some evidence of leaking at two expansion joints, however substantial amounts of the tracer have not reached the sampling ports. On the $3^{\text {td }}$ day after injection, February $12^{\text {th }}$, two leak areas are observed. One, at the first bustle (port 16-3) and the other is centered around the expansion joint (sampling location 22 , Figure 4) but is spread along a 20 to 25 foot section (sample locations 21, 22, and 23). This figure illustrates that there is substantial leakage along the entire length of the expansion joint on the northernmost side of the filter beds (sample location 22) as all four sampling ports indicate substantial o PDCH concentration. On February $14^{\text {th }}$, the contamination continues to spread around this region. The sampling port along the bustle (port 16-3) still remains high.

Figure 27 displays the o-PDCH concentration contours on the final day of the injection (February $16^{\text {th }}$ ), and at four days (February $20^{\text {th }}$ ) and six days (February $22^{\text {nd }}$ ) after the injection was stopped. On, February $16^{\text {th }}$, the tracer has spread further around the northernmost expansion joint near the filter bed. Spreading was also observed to the second sampling location (port 17-3) from the leak detected at 16-3. The profile appears similar to the profile found at the end of the preliminary tests using PDCB, Figure 24. As with PDCB, approximately 25 percent (11 of 43 ports) were within a factor of 2 of the peak measured value $1.8 \mathrm{ppb}$ and 50 percent ( 21 of 43 ports) were within a factor of 4 of the peak. 

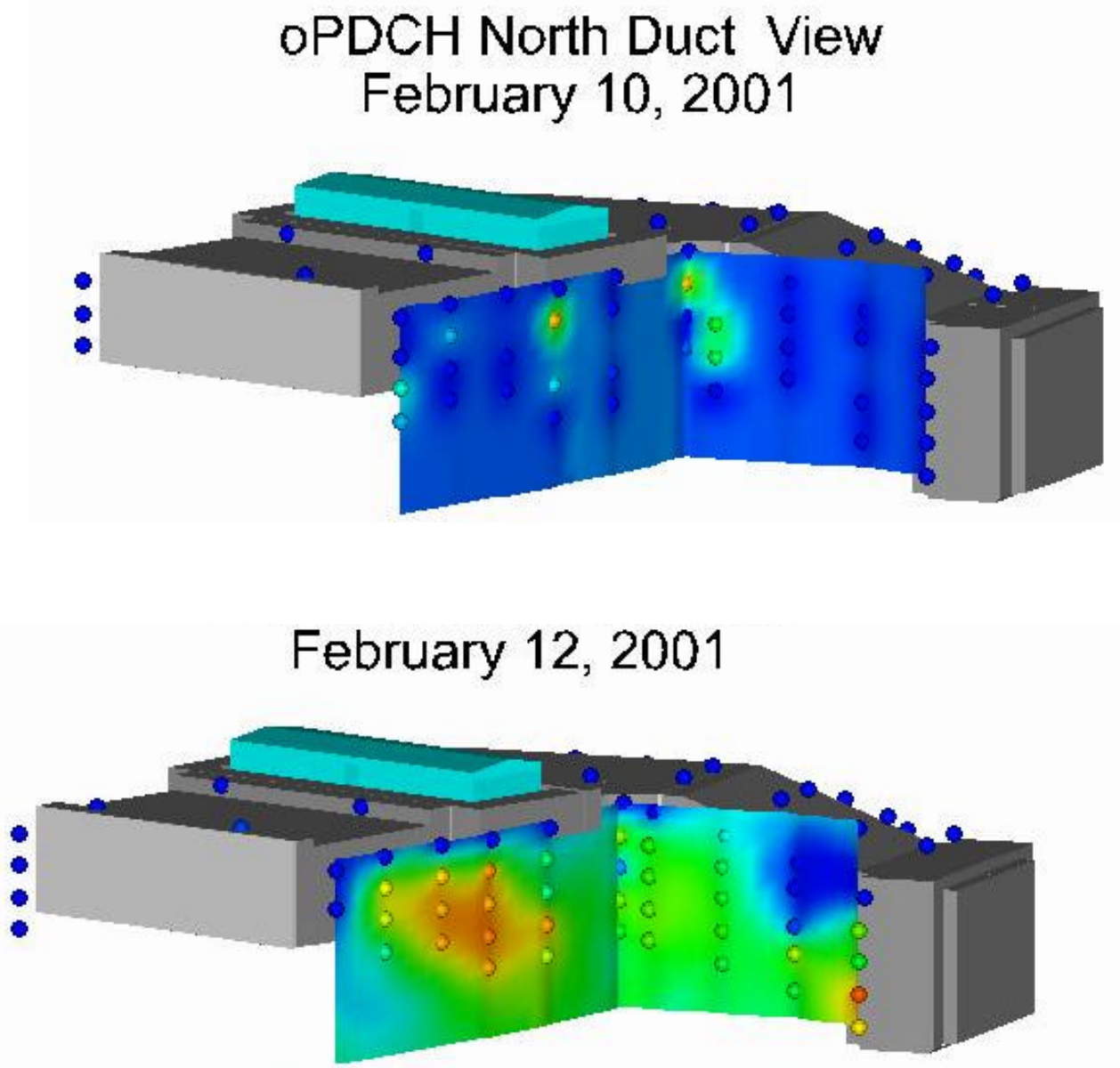

February 14, 2001

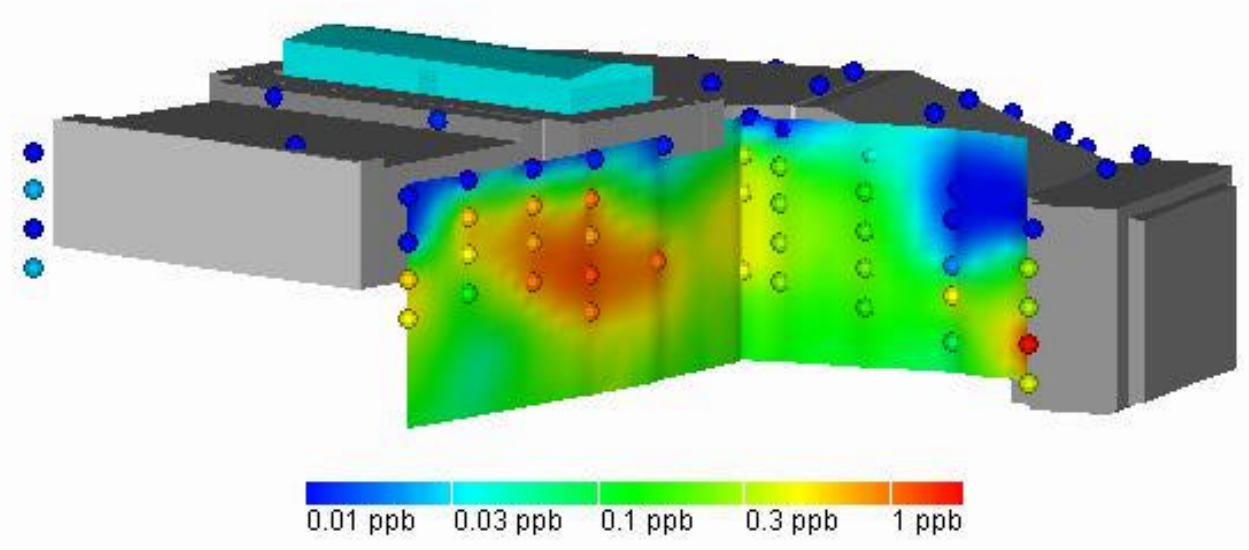

Figure 26. o-PDCH Concentrations on the first, third, and fifth day after the start of injection 


\section{oPDCH North Duct View February 16, 2001}

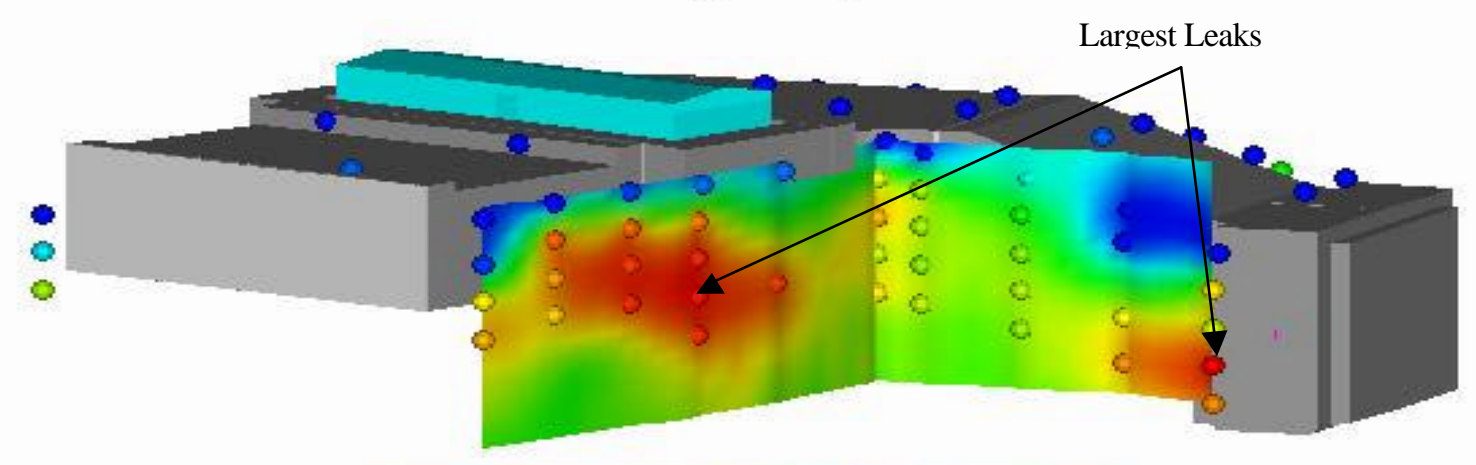

\section{February 20, 2001}

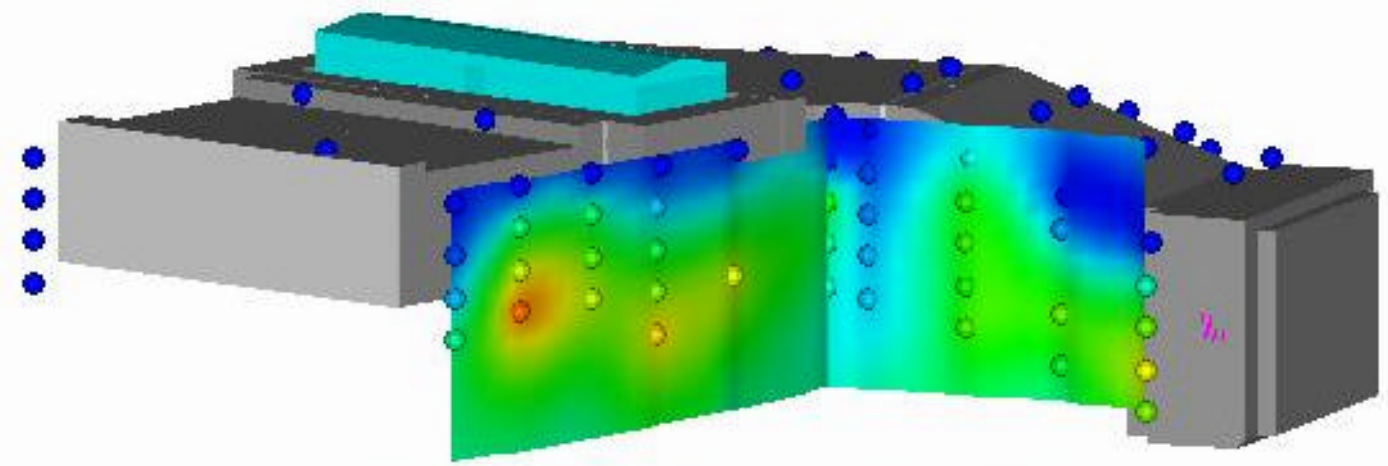

February 22, 2001

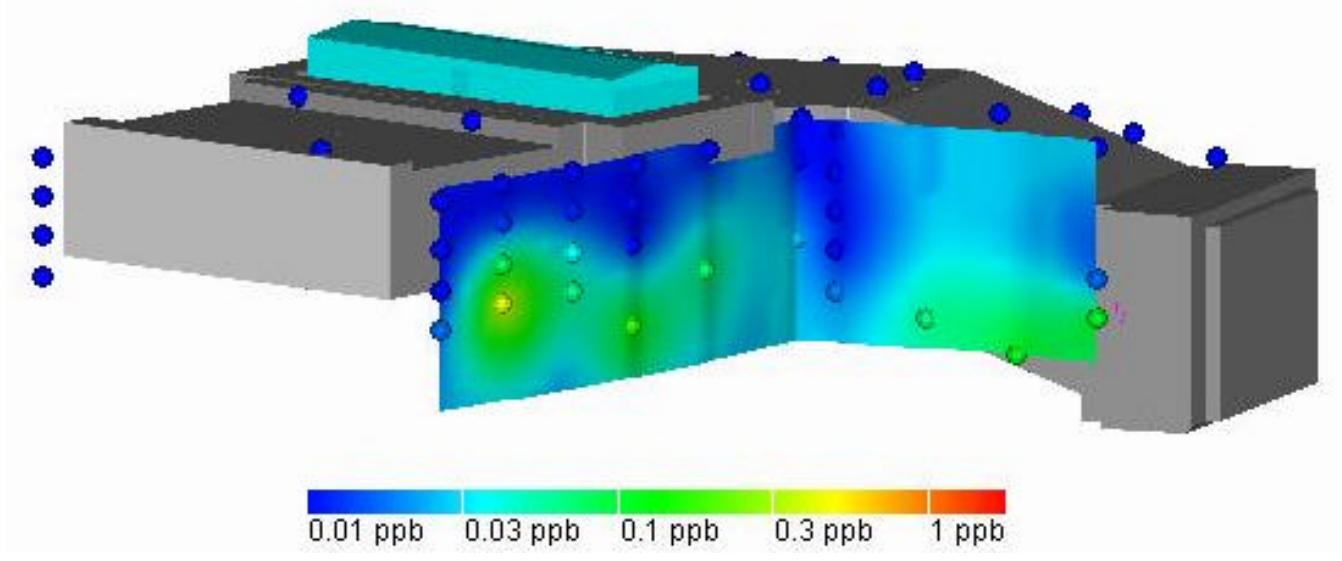

Figure 27. o-PDCH concentrations at the end of the injection (February 16th), fourth (February 20th), and sixth (February 22nd) days after the injection was stopped 
The data from February $20^{\text {th }}$ and $22^{\text {nd }}$ show a shift in the distribution of o-PDCH outside the north duct occurred after the injection was stopped. In general, the concentrations decreased, however, the peak concentration measured on the $20^{\text {th }}$ and $22^{\text {nd }}$ occurred at the bottom of sampling location 24 which is the first set of sampling ports from the bustle (and expansion joint) at the Instrument House. This indicates that there may be a leak at the bottom of the duct near this region. The potential for bottom leaks will be discussed later in the report.

The leak profile was stable during the injection test providing confidence that the information provided by the test is reliable. In addition, the leak profile of o-PDCH (second test) is similar to that found by PDCB (first test). This provides further confidence that all leak pathways from the north plenum to the surrounding soils have been defined. Similar graphical visualizations were generated for all tracers on all sampling dates. Examination of the concentration profiles for the tracer PMCP, injected in the north secondary plenum from February $7^{\text {th }}-9^{\text {th }}$, showed a similar leak pattern to the other tracers injected into the north duct (PDCB and o-PDCH). The tracer PMCH, injected in the south secondary plenum during the preliminary test, did appear outside the north duct at substantial concentrations. The leak pattern obtained from this tracer was slightly different than for the tracer injected into the North secondary plenum. This leak pattern will be discussed later in this report in the section titled "Cross-Talk".

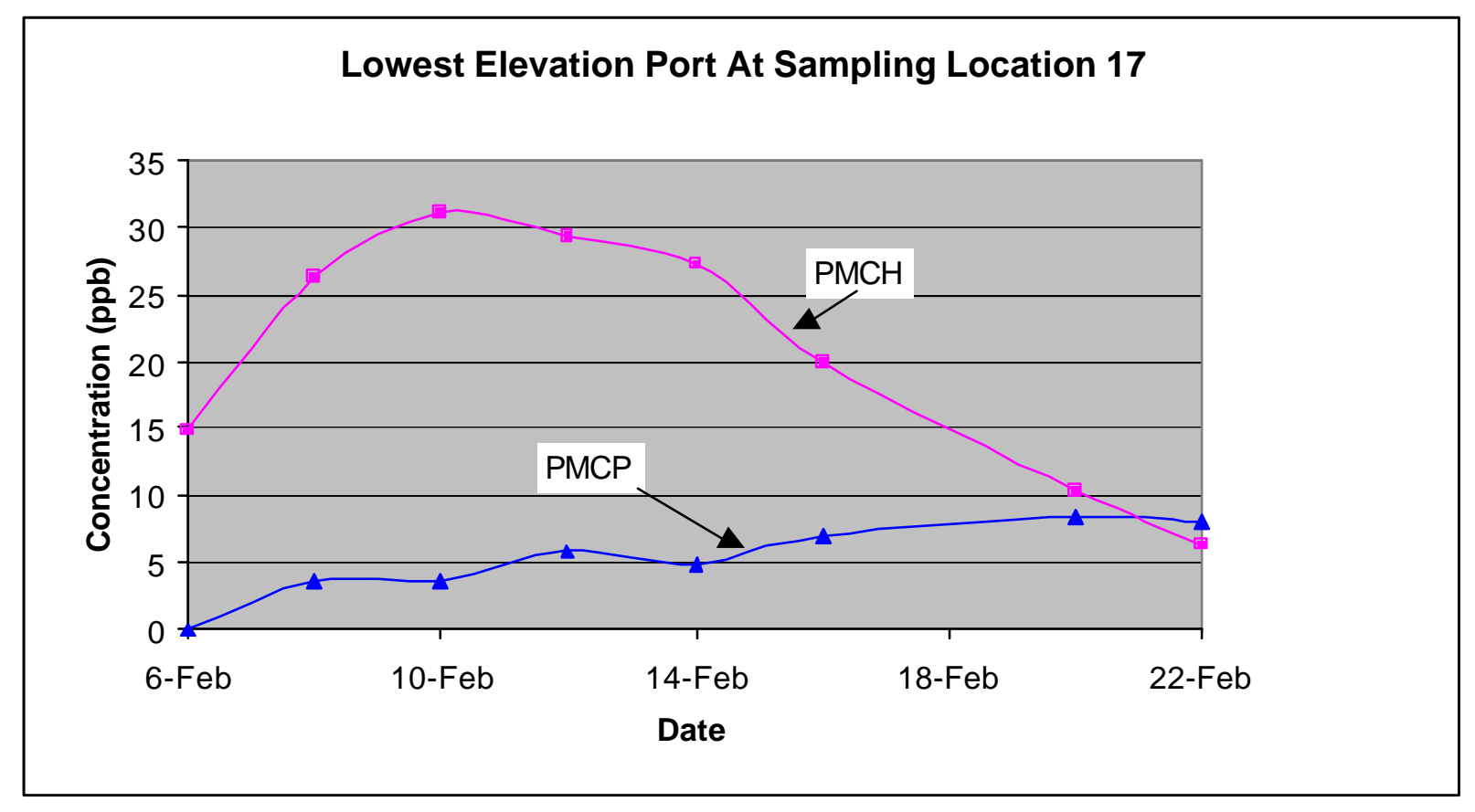

Figure 28. PDCB concentration at sampling port 16-3 


\section{Bottom Leaks}

It was not possible to place sampling ports directly underneath the below grade ducts. Therefore, determination of potential leak pathways along the bottom must take into account the time of arrival, the persistence over time, and the magnitude of the concentration. If a leak occurred along the bottom of the duct, it would need to travel a longer distance than if it occurred on the side of the duct, where the monitoring ports are located. The longer the time lag, the further the leak is probably from the sampling port. Figure 28 presents the time evolution of the tracer PDCB used in the preliminary test at port 16-3. This port lies along the north duct and was identified as having one of the largest leak rates. The graph begins at the end of the injection period and continues for two weeks. For sampling ports near a leak, the concentration declines quickly once the injection is stopped on February $6^{\text {th }}$ as displayed in the figure. This profile is typical for sampling ports located near a leak.

Figure 29 presents the time evolution of $\mathrm{PMCH}$ and $\mathrm{PMCP}$ at sampling port 17-4. This sampling port is at an elevation just beneath the bottom of the duct and is ten feet further away from Building 701 than sampling location 16, the first along this duct. These two tracers were both injected in the south duct. The PMCH injection was stopped on February $6^{\text {th }}$. However, it did not reach its peak concentration until February $10^{\text {th }}$ at this location. It remained relatively constant for several days before slowly declining. PMCP was injected in the north duct on February $7^{\text {th }}-9^{\text {th }}$ and on the south duct on February $7^{\text {th }}-16^{\text {th }}$. Even though it is injected along the north duct for a few days, the concentration at this location continues to rise slowly peaking on February $20^{\text {th }}$, four days after the injection had been stopped in the south duct and 11 days after the injection had been stopped in the north duct. This type of evolution in concentration over time is indicative of leakage from a source that is fairly far removed from the monitoring location. Therefore, since this location is below the bottom of the duct, it indicates a leak from underneath the duct.

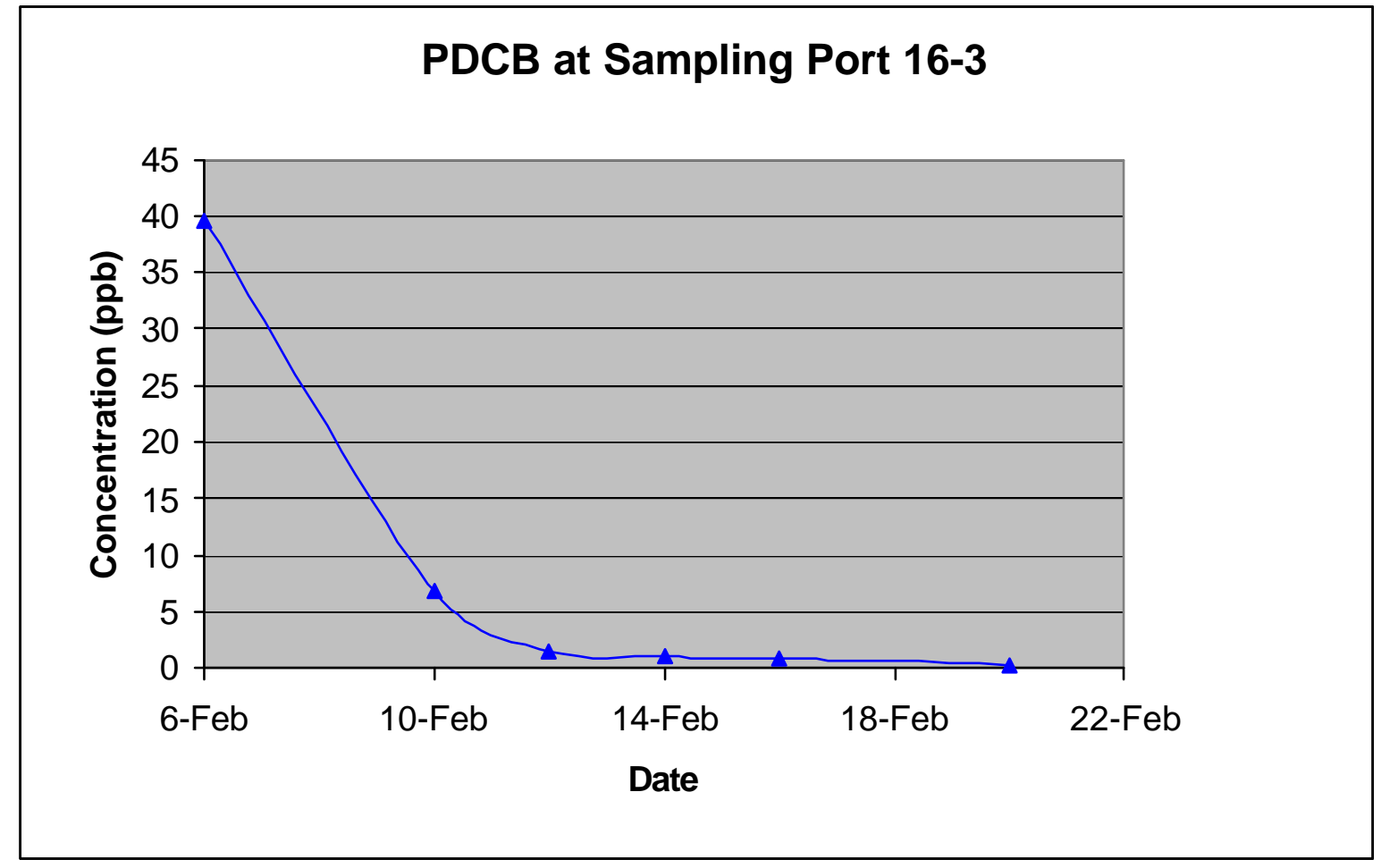

Figure 29. $\mathrm{PMCH}$ and PMCP concentrations at sampling port 17-4 
The lowest elevation at each external port was evaluated for the potential of indicating a bottom leak. Sample locations 1-15 and 42 outline the south duct while sample locations $16-25$ outline the north duct. In addition to examining the concentration profiles at the lowest elevation, the profiles were compared to the neighboring ports to determine if the evidence for a bottom leak could be attributed to known leaks along the side of the ducts.

\section{South Duct}

Figure 30 presents a side view of the south duct. Arrows point to the sampling ports with the most evidence for a bottom leak. Solid lines indicate strong evidence of a leak (for example, several tracers indicate a bottom leak) while dotted lines indicate some evidence of a leak (one or two of the four tracers indicate a bottom leak). Sample locations 12 and 42 provide strong evidence of a bottom leak. In some cases, if a large leak was present on the side of the duct, it is difficult to determine if a bottom leak exists. This is due to the dilution that occurs traveling from the leak to the sampling point. The further the travel distance, the greater the dilution. This occurred at sampling locations 2 and 11 and is reflected by the dotted line indicating a potential bottom leak.

\section{South Duct Potential Bottom Leaks}

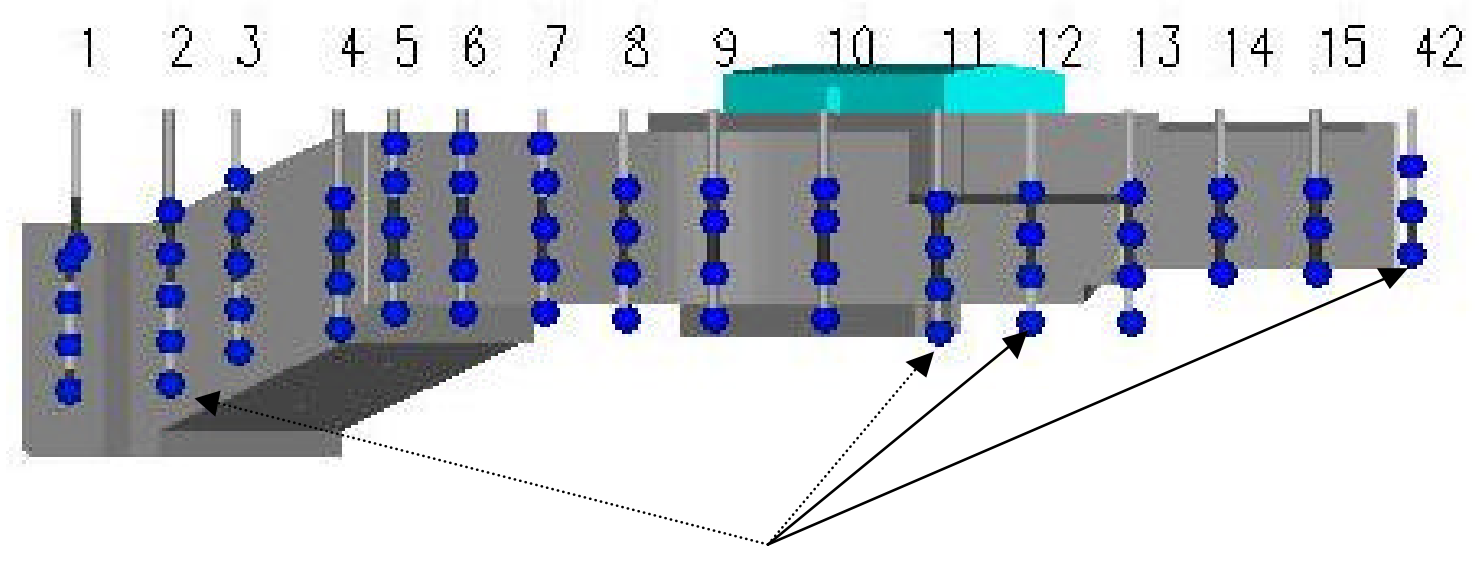

Figure 30. Sample locations with evidence of a leak along the bottom of the duct

\section{North Duct}

Figure 31 presents a side view of the north duct. Arrows point to the sampling ports with the most evidence for a bottom leak. Solid lines indicate strong evidence of a leak while dotted lines indicate some evidence of a leak. In some cases, if a large leak was present on the side of the duct, it is difficult to determine if a bottom leak exists. Sample locations 17 and 24 showed strong evidence of a leak along the bottom in the vicinity of these ports. Sample locations 16 and 22 showed some evidence of a bottom leak, however due to the presence of relatively major leaks in the side of the duct in these regions, it is not possible to conclusively state that there is a bottom leak in these regions. 


\section{North Duct Potential Bottom Leaks}

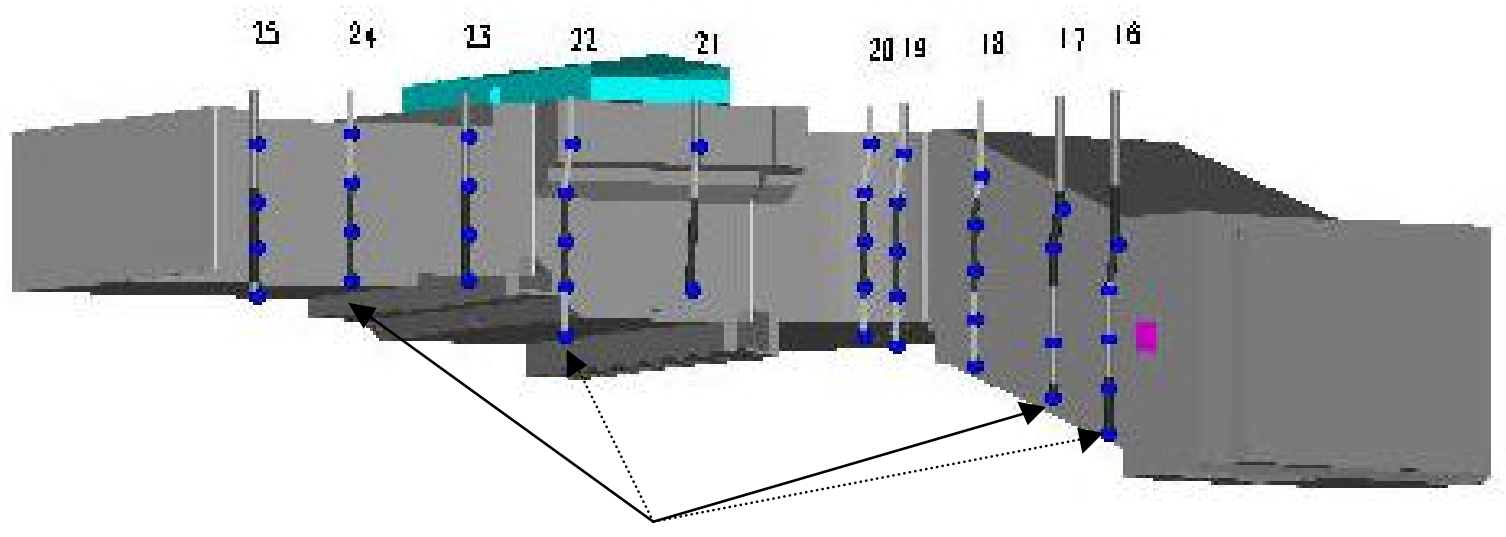

\section{Evidence of Bottom Leaks}

Figure 31. North duct potential bottom leak locations

\section{Top Leaks}

Samples were collected one to three feet above the ducts along the centerline of each duct. No substantial leaks were observed during the test period. Peak measured values for all tracers along the top of the ducts were a factor of ten to 100 lower than values measured along the sides of the ducts. This indicates leakage was minimal along the top. Figure 32 shows the sampling locations and color-coded values for PMCH on February $12^{\text {th }}$. Color-coding is normalized to the maximum value measured at any port on that day. The absence of red, orange or yellow regions reflects that the concentrations are low as compared to other ports elsewhere on that day. Sampling port 30 was not measured on February $12^{\text {th }}$ due to flooding of the port. For illustrative purposes, the values measured at port 30 on February $16^{\text {th }}$ were added to the figure. Sampling port 37-1 regularly had the highest values of all top ports for all 4 tracers. Peak concentrations at this location were always observed several days after arrival of the tracer at port 18-S. This indicates the leak location is not in the top of the duct, but more likely on the side near port 18-S. Port 18-S consistently had the highest measured values for all tracers near the surface. Sampling port 28 also showed relatively high values. Sample port 41 showed relatively high values for the two tracers (PMCP and o-PDCH). 


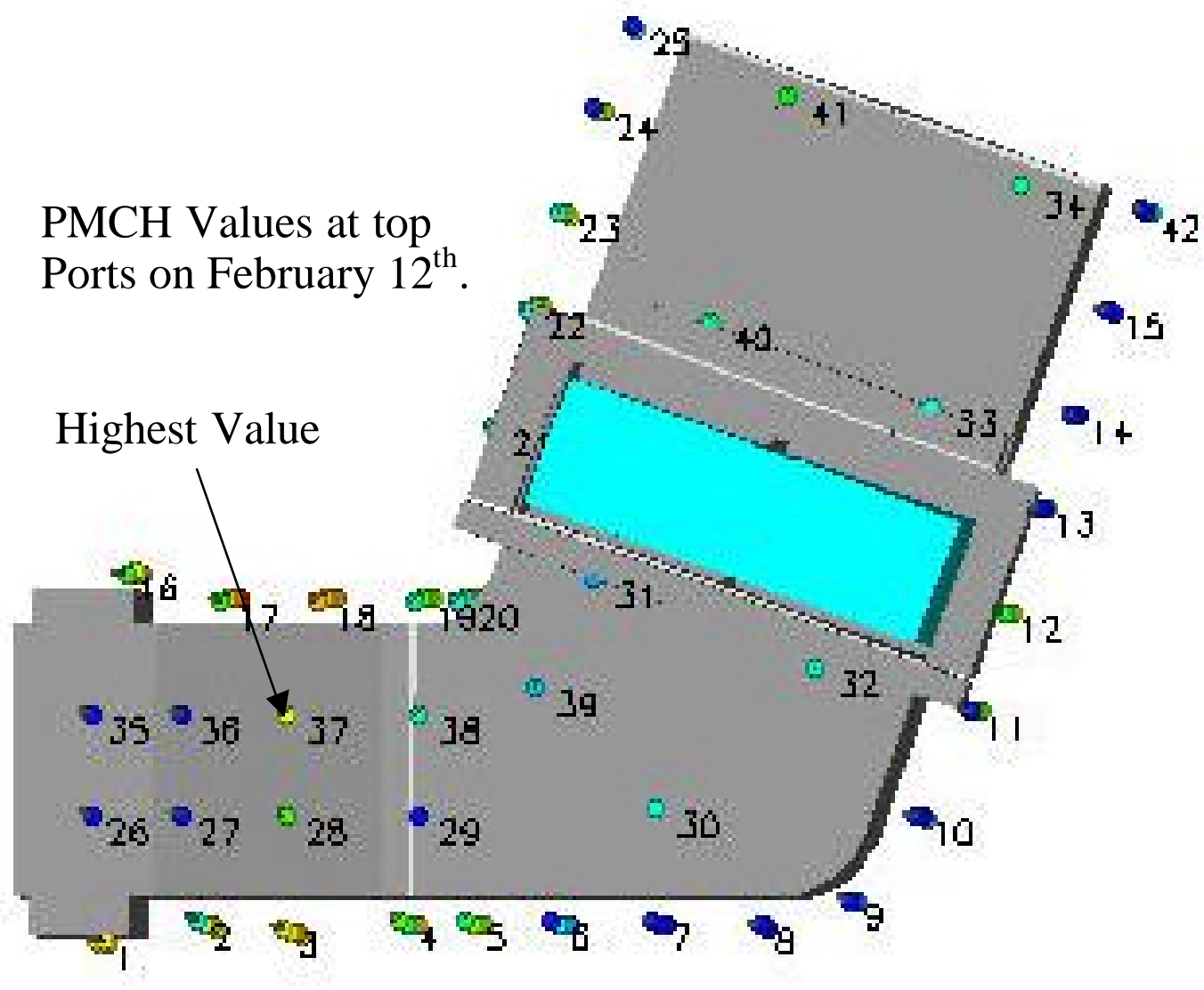

Figure 32. Example of PFT concentrations along the top of the two below grade ducts

\section{Cross-Talk}

The tracer injected in the south secondary plenum (PMCH) routinely was found at sampling ports along the north duct at high concentrations. Conversely, tracers injected into the north secondary plenum (PDCB and o-PDCH) were found outside the south duct. The tracer PMCP was injected into both plenums so it is difficult to determine the original source of the tracer and it will not be used to determine the cross-talk between tracers injected in one side and detected in the other.

The tracer PMCH was injected from January $30^{\text {th }}$ through February $6^{\text {th }}$ in the south secondary plenum. The leak pattern found on the north duct from $\mathrm{PMCH}$ differed substantially from that found from the tracers injected into the north secondary plenum. Figure 33 displays the PMCH contours along the north duct on the first and fourth day after the injection was stopped. The largest leaks are along the expansion joint (sampling location 19) and the adjacent sampling location nearer to Building 701 (sampling location 18). In contrast, for the tracers injected in the north duct, the largest leak was at the expansion joint in the bustle near Building 701 (port 16-3) and at the expansion joint just past the filter bed region (port 22-3). Peak measured PMCH concentrations along the north duct were near $80 \mathrm{ppb}$, approximately the same as found at the largest leaks outside the south duct. 
PMCH can take three general pathways to reach the north side of the duct. It can be released from the south duct and move through the soil to the north side. If this were to occur, substantial dilution would occur in traveling the 30 to 35 feet across the exterior of the ducts. The time to travel this distance would be on the order of two weeks or longer. Also, the tracer would appear at the top or bottom of the ducts in higher concentrations than the side of the duct. Thus, the source of PMCH is clearly not leakage out the south duct and then transport to the morth side of the ducts.

The second transport pathway would be to mix with the gas in the plenum beneath the BGRR and be drawn into the secondary plenum on the north side. This mixing was followed by measuring the amount of PMCH in the north secondary plenum over the duration of the tests. During the injection period, the internal PMCH concentration in the south plenum averaged $108 \mathrm{ppb}$. Due to internal cross contamination, the north secondary plenum averaged a concentration of $9.9 \mathrm{ppb}$. The tracer concentrations found outside the north duct were almost $80 \mathrm{ppb}$. Thus, leakage from the north duct directly to the outside could not account for the observed concentration profile. Further, there would be no reason why the profile obtained from leaking from the interior should differ from the tracers injected directly into the duct.

The third transport pathway involves release from the south secondary plenum and movements within the ducts and exterior to the secondary plenum until the tracer is released along the north duct. The fact that the measured external PMCH concentrations are higher than the concentrations in the secondary plenum on the north side indicates that the source of contamination is a leak in the south duct.

Although this is a viable transport pathway for the gas tracer, it is not likely to be a transport pathway for water. It is difficult to determine a credible scenario that would provide a hydraulic gradient to move water around and through the ducts.

For the tracers injected in the north secondary plenum (PDCB and o-PDCH) a similar event occurred. The highest measured concentrations along the south duct were greater than the concentration in the south secondary plenum (average PDCB $0.7 \mathrm{ppb}$ and o-PDCH $0.084 \mathrm{ppb}$ ). The highest measured concentrations for these tracers occurred at the expansion joint at the front of the filter bed region (sampling location 11-4, PDCB $8.4 \mathrm{ppb}$ and o-PDCH $0.28 \mathrm{ppb}$ ) and at the expansion joint in the bustle region near the Instrument House (sampling location 42-4, $\mathrm{PDCB}=8.1$ and $\mathrm{o}-\mathrm{PDCH}=0.28 \mathrm{ppb}$ ). This again suggests release from the north plenum and transport to the south side and release at the expansion joints. Again, it is not likely that this presents a hydraulic flow pathway. For this reason, data from tracers injected into the south plenum are believed to provide greater accuracy in defining leak locations along the south duct.

Thus both sets of data indicate a well-connected air pathway exterior to the secondary plenum but confined within the exterior of the ductwork. The net transfer was greater from the south plenum to the north side, consistent with the net transfer from the south secondary plenum to the north secondary plenum. 


\section{PMCH North Duct View February 6, 2001}

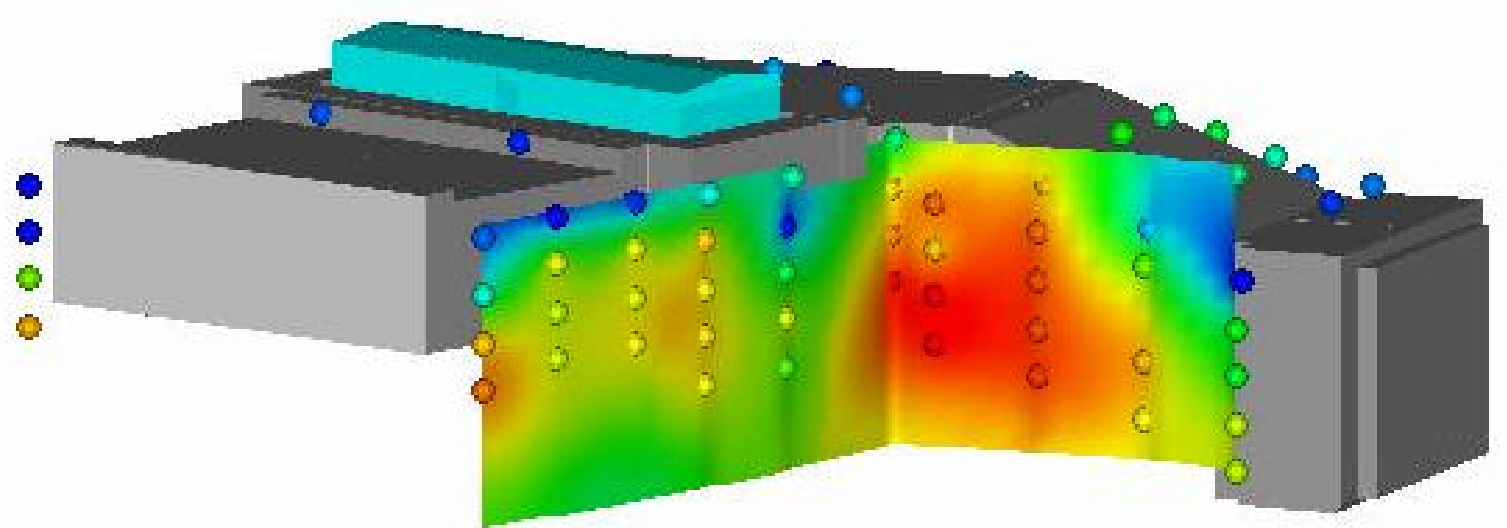

\section{February 9, 2001}

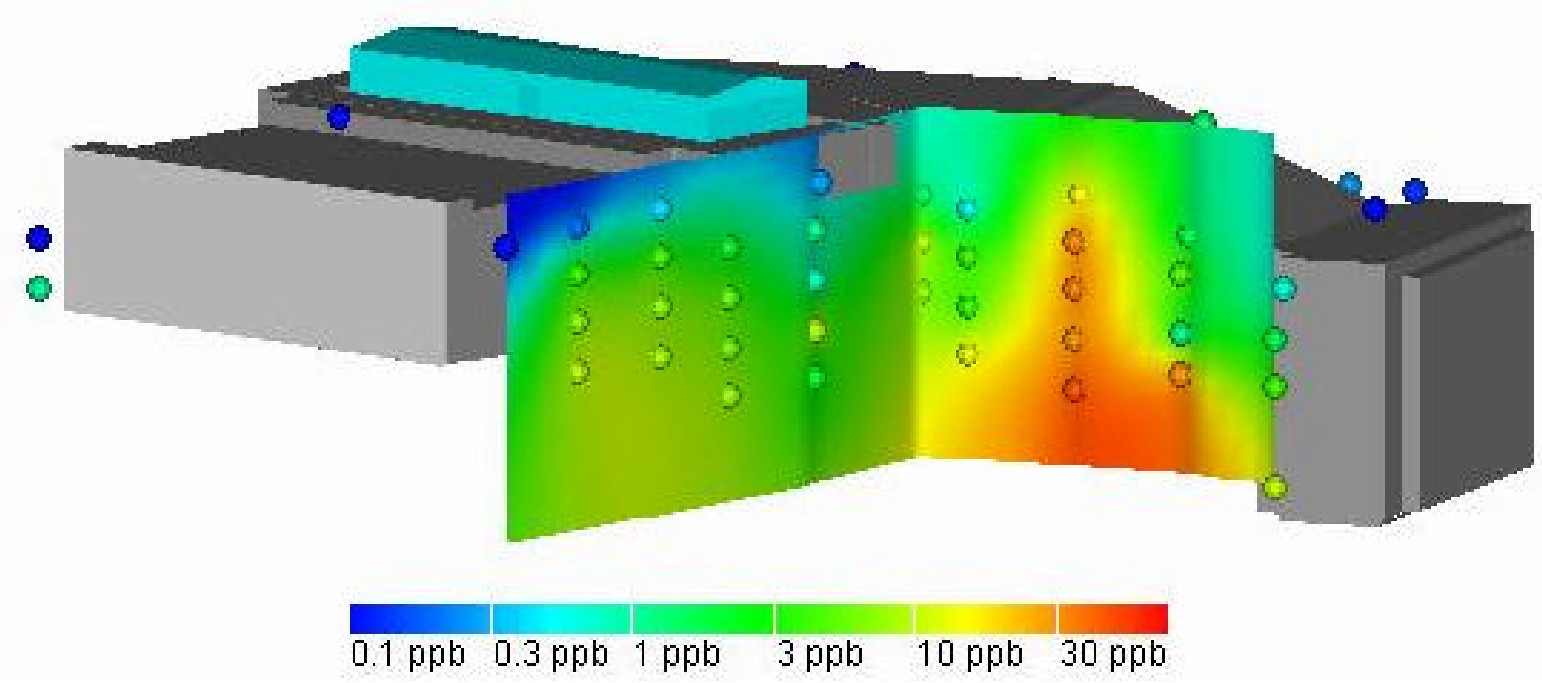

Figure 33. PMCH concentrations along the north duct one and four days after the injection was stopped 


\section{LEAK LOCATION SUMMARY}

The visualizations provided in Figures 21 - 33 present information on tracer concentrations around the below grade ducts for the four tracers. An analysis was performed to evaluate the location of potential leaks through examining the entire data set. Tables III and IV present the information on potential leak locations at the south duct and north duct, respectively. The tables contain the sample location identifier, a narrative description of the leak location, a normalized leak size, and comments. The size of the leak can be related to the peak measured value outside of the duct. The normalized leak size was obtained for each tracer by taking the highest meas ured value along a duct and then dividing the measured concentrations along the duct by that value. Thus, the largest leak (as determined by the highest measured concentration) has a normalized leak size of one. Therefore, the values in Table III and IV should be evaluated for each individual tracer and different tracers may not be directly comparable (e.g. a normalized leak rate of one from one tracer does not necessarily reflect an equal size leak as another tracer with a normalized leak size of one). The data in Table III and IV are from the day after the injection of the tracer was stopped. In all cases, this day had the highest value measured for that tracer during the test. In general, the data from day to day provided a consistent picture of leakage from the duct and similar analysis on different days was performed and provided essentially the same information.

\section{South Duct}

A distinct difference was noted between the leak locations identified by tracers injected into the north secondary plenum as compared to those injected into the south secondary plenum. For tracers injected in the north plenum, the largest leaks occurred at the bottom of two expansion joints (sample location 11-4, filter bed, and 42-4 instrument house). The concentration for these tracers along the exterior of the south duct was greater than the concentration in the south secondary plenum, indicating the source was the north secondary plenum. For tracers injected into the south plenum, the largest leak occurred at the expansion joint in the first bustle near sampling ports 1-2 and 1-3. The port 1-2 is near the mid-point of the plenum and the port 1-3 is about two feet above the bottom of the plenum. The high water mark in the plenum was approximately one to two feet below sample port 1-2 and a few feet above sample port 13. Another leak was identified at the first expansion joint (ports 43 and 4-4). A possible leak at ports 2-3 and 2-4 was also identified. Large regions of the south duct indicated little or no leakage. This included port locations 5-10 and 13-15 (see Figure 17). There was evidence of some leakage at four of the five expansion joints. The expansion joint at the edge of the filter bed and nearest to the instrument house did not indicate any leakage (sample location 13). 
Table III: Potential leak locations along the south duct

\begin{tabular}{|c|c|c|c|}
\hline \multicolumn{4}{|c|}{ PDCB Injected in the north secondary plenum. Peak value outside south duct $8.6 \mathrm{ppb}$ on February $6^{\text {th }}}$. \\
\hline Location & Location Description & Normalized Leak Size & Comments \\
\hline $11-4$ & $\begin{array}{l}\text { Expansion joint in filter } \\
\text { bed }\end{array}$ & 1 & \\
\hline $42-4$ & $\begin{array}{l}\text { Expansion joint in bustle } \\
\text { near instrument house }\end{array}$ & 0.94 & \\
\hline $4-3$ & $\begin{array}{l}\text { Expansion joint elevation } \\
\text { above the bottom of the } \\
\text { secondary plenum }\end{array}$ & 051 & \\
\hline Location & Location Description & Normalized Leak Size & Comments \\
\hline $12-4$ & $\begin{array}{l}\text { Middle of the filter house, } \\
\text { bottom Elevation. }\end{array}$ & 0.43 & Possible bottom leak between 11 and 12 \\
\hline $1-2 ; 1-3$ & $\begin{array}{l}\text { Expansion joint near } \\
\text { Building 701, middle of } \\
\text { the plenum }\end{array}$ & 0.28 & $\begin{array}{l}\text { Relatively large leak identified by tracers } \\
\text { injected into the south secondary plenum }\end{array}$ \\
\hline \multicolumn{4}{|c|}{ O-PDCH Injected in the north secondary plenum. Peak value outside south duct $0.29 \mathrm{ppb}$ on February $16^{\text {th }}$. } \\
\hline $42-4$ & See above & 1 & \\
\hline $11-4$ & See above & 0.95 & \\
\hline $12-4$ & See above & 0.31 & Possible bottom leak between 11 and 12 \\
\hline $1-2: 1-3$ & See above & 0.19 & $\begin{array}{l}\text { Samples had almost identical } \\
\text { concentrations }\end{array}$ \\
\hline $4-4: 4-3$ & See above & 0.19 & $\begin{array}{l}\text { Samples had almost identical } \\
\text { concentrations }\end{array}$ \\
\hline \multicolumn{4}{|c|}{ PMCP Injected in North and South Secondary Plenum. Peak Value outside south duct 15.3 ppb on February 16} \\
\hline $1-2$ & See above & 1 & \\
\hline $1-3$ & See above & 0.84 & \\
\hline $42-4$ & See above & 0.31 & \\
\hline $2-3 ; 2-4$ & $\begin{array}{l}\text { See } 2-3 \text { above. } 2-4 \text { five } \\
\text { feet lower and is below } \\
\text { the bottom of the duct }\end{array}$ & 0.28 & $\begin{array}{l}\text { Samples had almost identical } \\
\text { concentrations }\end{array}$ \\
\hline $4-4 ; 4-3$ & See 4-3 above & 0.23 & $\begin{array}{l}\text { Samples had almost identical } \\
\text { concentrations }\end{array}$ \\
\hline $3-4$ & $\begin{array}{l}10 \text { feet closer to the } \\
\text { building than the first } \\
\text { expansion joint, bottom } \\
\text { elevation below the duct }\end{array}$ & 0.18 & \\
\hline $11-4$ & See above & 0.12 & \\
\hline $12-4$ & See above & 0.11 & \\
\hline \multicolumn{4}{|c|}{ PMCHInjected in South Secondary Plenum. Peak Value outside south duct 82.5 ppb on February $6{ }^{\text {th }}$. } \\
\hline $1-2$ & See above & 1 & \\
\hline $1-3$ & See above & 0.92 & \\
\hline $4-3$ & See above & 0.46 & \\
\hline $2-3$ & $\begin{array}{l}10 \text { feet from the first } \\
\text { expansion joint two to } \\
\text { three feet above the } \\
\text { bottom of the plenum }\end{array}$ & 0.30 & $\begin{array}{l}\text { Possible movement from leak at } 1-2 \text { and } \\
1-3\end{array}$ \\
\hline $42-4$ & See above & 0.29 & \\
\hline
\end{tabular}




\section{North Duct}

Table IV presents the information on potential leak locations at the north duct. Again a distinct difference was noted between the leak locations identified by tracers injected into the north secondary plenum as compared to those injected into the south secondary plenum. For tracers injected in the north plenum, the largest leaks occurred at the first bustle region (16-3) and along the expansion joint at the filter bed nearest to the instrument house (sample location 22). Relatively substantial leaks were found on both sides of this expansion joint at sample locations 21, 23, and 24. At each of these locations several ports showed high values of the tracer. This indicated a fairly uniform leak along this wall. For the tracer $\mathrm{PMCH}$, which was only injected into the south plenum, a different leak pattern emerged. Relatively large leakage was found at expansion joint approximately 40 feet out from Building 701, at sample location 19. Substantial values of PMCH were also found leaking in adjacent sample locations (18 and 20). The concentrations for PMCH (70 - $80 \mathrm{ppb})$ were much higher than found in the north secondary plenum (10 $\mathrm{ppb}$ ). This indicates that the source of this tracer was the south plenum (concentration $100 \mathrm{ppb}$ ) and that the gas was transported from the leak in the south plenum to the north plenum without much dilution (mixing). This indicates that it is not a likely pathway for movement of water. Leakage was detected at each expansion joint. In general, leakage out of the north duct was more significant than out of the south duct.

\section{Bottom Leaks}

The potential for bottom leaks was discussed in the previous section. On the south duct, sample locations 12 (middle of the filter bed) and 42 (expansion joint at the instrument house) provided evidence of a bottom leak. In some cases, if a large leak is present on the side of the duct, it is difficult to determine if a bottom leak exists. This is due to the dilution that occurs traveling from the leak to the sampling point. The further the travel distance, the greater the dilution. This occurred at sampling locations 2 (10 feet from the expansion joint near Building 701) and 11 (expansion joint at the filter bed). On the north duct, sample locations 17 (10 feet from the expansion joint near Building 701) and 24 (10 feet from the expansion joint in the Instrument House) showed strong evidence of a leak along the bottom in the vicinity of these ports. Sample locations 16 (expansion joint near Building 701) and 22 (expansion joint at the filter bed nearest to the Instrument House) showed some evidence of a bottom leak, however due to the presence of relatively major leaks in the side of the duct in these regions, it is not possible to conclusively state that there is a bottom leak in these regions. 
Table IV: Potential leak locations along the north duct

\begin{tabular}{|c|c|c|c|}
\hline Location & Location Description & Normalized Leak Size & Comments \\
\hline $\begin{array}{l}22-3,22-4,22- \\
1,22-2\end{array}$ & $\begin{array}{l}\text { Expansion joint on the filter bed } \\
\text { nearer to instrument house }\end{array}$ & $1-0.72$ & $\begin{array}{l}\text { Appears to be leaking almost uniformly out of } \\
\text { the expansion joint }\end{array}$ \\
\hline $16-3$ & $\begin{array}{l}\text { Expansion joint in the bustle near } \\
\text { Building } 701 \text {, approximately two } \\
\text { feet above the bottom of the } \\
\text { plenum }\end{array}$ & 0.96 & \\
\hline $\begin{array}{l}23-4,23-2,23- \\
3\end{array}$ & $\begin{array}{l}\text { Between expansion joint at the } \\
\text { filter bed and the instrument } \\
\text { house, approximately } 9.5 \text { feet } \\
\text { from the filter bed. }\end{array}$ & $085-0.62$ & $\begin{array}{l}\text { Could be two separate leaks at elevations } 4 \text { and } \\
2 \text {, or could be a fairly uniform leak along the } \\
\text { side }\end{array}$ \\
\hline $\begin{array}{l}24-4,24-2,24- \\
3\end{array}$ & $\begin{array}{l}\text { Between expansion joint at the } \\
\text { filter bed and the instrument } \\
\text { house, approximately } 19.5 \text { feet } \\
\text { from the filter bed }\end{array}$ & $0.59-0.53$ & Uniform leak along this sample location \\
\hline $19-1$ & $\begin{array}{l}\text { Expansion joint, elevation one to } \\
\text { two feet below the top of the } \\
\text { plenum }\end{array}$ & 0.39 & $\begin{array}{l}\text { Probably not a water leak pathway due to high } \\
\text { elevation }\end{array}$ \\
\hline $25-4$ & $\begin{array}{l}\text { Expansion joint in the bustle near } \\
\text { the instrument house }\end{array}$ & 0.35 & \\
\hline \multicolumn{4}{|c|}{ o-PDCH Injected in the north secondary plenum. Peak value outside north duct $1.77 \mathrm{ppb}$} \\
\hline Location & Location Description & Normalized Leak Size & Comments \\
\hline $16-3$ & See above & 1 & \\
\hline $\begin{array}{l}22-3,22-2,22- \\
4\end{array}$ & See above & $0.9-0.8$ & Uniform leak along the expansion joint \\
\hline $\begin{array}{l}23-4,23- \\
3,23-2\end{array}$ & See above & $0.8-0.6$ & Uniform leak along this sample location \\
\hline $21-3$ & $\begin{array}{l}\text { Middle of the filter bed between } \\
\text { two expansion joints }\end{array}$ & 0.71 & \\
\hline $\begin{array}{l}24-2,24-3,24- \\
4\end{array}$ & See above & $0.58-0.32$ & \\
\hline $16-4$ & Five feet below 16-3 (see above) & 0.48 & Probably from the leak at $16-3$ \\
\hline $17-4$ & $\begin{array}{l}\text { Approximately ten feet from the } \\
\text { bustle }\end{array}$ & 0.46 & Possibly from the leak at $16-3$ \\
\hline \multicolumn{4}{|c|}{ PMCH Injected in south secondary plenum. Peak value outside the south plenum $78.7 \mathrm{ppb}$. } \\
\hline $19-4,19-3$ & Expansion joint & $1-0.97$ & \\
\hline $20-3$ & $\begin{array}{l}\text { Five feet past sample location } 19 \\
\text { toward the filter house }\end{array}$ & 0.94 & $\begin{array}{l}\text { Sample port } 20-4 \text { was not measured on this day. } \\
\text { It typically had values similar to } 20-3 \text { when } \\
\text { measured on the same day. }\end{array}$ \\
\hline $\begin{array}{l}18-4,18-2,18- \\
3,18-1\end{array}$ & $\begin{array}{l}\text { Between expansion joint in the } \\
\text { bustle near Building } 701 \text { and first } \\
\text { expansion joint, approximately } \\
\text { ten feet from the first expansion } \\
\text { joint. }\end{array}$ & $0.69-0.51$ & $\begin{array}{l}\text { Fairly uniform leakage along this sampling } \\
\text { location }\end{array}$ \\
\hline $19-1$ & See above & 0.50 & \\
\hline $25-4$ & See above & 0.45 & \\
\hline $20-2$ & See above & $\begin{array}{r}0.4 \\
\end{array}$ & \\
\hline \multicolumn{4}{|c|}{$\begin{array}{l}\text { PMCP Injected in south secondary plenum. Peak value outside north duct } 78.7 \mathrm{ppb} \text { on February } 10^{\text {th }} \text { Values quoted in this table are from } \\
\text { February } 10^{\text {th }} \text { and reflect the early stages of release. }\end{array}$} \\
\hline $22-3,22-1$ & See above & $1-0.97$ & Suggests two distinct leaks \\
\hline $23-3,23-4$ & See above & $0.95-0.85$ & \\
\hline $24-2$ & See above & 0.8 & \\
\hline $20-1$ & See above & 0.86 & \\
\hline $16-3$ & See above & 0.82 & \\
\hline $21-3$ & See above & 0.75 & \\
\hline $25-4$ & See above & 0.45 & \\
\hline
\end{tabular}




\section{CONCLUSIONS}

The focus of this program was the characterization of the soils beneath the main air ducts connecting the exhaust plenums with the Fan House. The air plenums experienced water intrusion during BGRR operations and after shutdown. The water intrusions were attributed to rainwater leaks into degraded parts of the system and to internal cooling water system leaks. As part of the overall characterization efforts, a state-of-the-art gaseous perfluorocarbon tracer technology was utilized to characterize leak pathways from the ducts. This in turn suggests what soil regions under or adjacent to the ductwork should be emphasized in the characterization process. Knowledge of where gaseous tracers leak from the ducts yields a conservative picture of where water transport, out of or into, the ducts might have occurred.

The PFT leak tests involved injection of a tracer into the secondary air plenum of the north and south duct. Separate tracers were injected in each duct. Two tests were conducted. The first was used to determine internal communication between the secondary air plenum and the primary air plenum. This information was used to determine the flow rates needed for the second test which focused on detection of leakage from the plenum to the surrounding soils. The first injection period lasted from January $30^{\text {th }}$ through February $6^{\text {th }}$. The tracer PDCB was injected into the north duct and PMCH was injected into the south duct. During this time gas samples were collected from several locations within the interior of the ducts and connected areas to follow the buildup of the tracer within the system. A complete set of soil gas samples was collected on February $6^{\text {th }}$ and analyzed for these two tracers. The leak test involved injection of PMCP in the south duct from February $7^{\text {th }}$ to $16^{\text {th }}$. Due to a labeling error, PMCP was also injected into the north duct from February $7^{\text {th }}$ to $9^{\text {th }}$. Once the error was detected, the source of PMCP was replaced with o-PDCH from February $9^{\text {th }}$ to $16^{\text {th }}$. Complete sampling of all soil ports and duct internal ports was performed on February $9^{\text {th }}, 10^{\text {th }}, 12^{\text {th }}, 14^{\text {th }}, 16^{\text {th }}, 20^{\text {th }}$, and $22^{\text {nd }}$. This data was analyzed to determine potential leak pathways along the side, top, and beneath the ducts.

The major findings of this analysis are:

South duct:

- The largest leak is in the region of the expansion joint in the bustle near Building 701. This leak was near the high water mark found in this duct.

- The second largest leak was found at the expansion joint approximately 40 feet from Building 701.

- Some evidence of leakage was found at four of the five expansion joints.

- There was strong evidence of a leak along the bottom of the duct in the filter bed region and at the expansion joint near the instrument house.

- Large regions of the south duct are not leaking gas. Other than the region between the first two expansion joints, there was no evidence of leakage away from the expansion joints.

North duct

- The largest leak is in the region of the expansion joint in the bustle near Building 701. This leak is below the high water mark found in this duct.

- A similar size leak was found along the expansion joint in the filter bed nearest to the instrument house. This leak appeared to occur fairly uniformly along the length of the expansion joint.

- Considerable leakage was observed on either side of this expansion joint.

- There was strong evidence of a leak along the bottom of the duct approximately ten feet past the bustle near Building 701 and ten feet before the expansion joint at the instrument house.

- The north duct leaked at a much higher rate than the south duct. Evidence of leakage was detected at most sampling locations. 
The information gained in this study can be used to guide and optimize soil characterization studies around the below grade ducts that will be conducted. Combining this information with process knowledge will permit an improved sampling plan to be developed.

\section{REFERENCES}

J. HEISER and B.P. DWYER, "Summary Report on Close-Coupled Subsurface Barrier Technology Initial Fie ld Trials to Full-Scale Demonstration", Brookhaven National Laboratory, Upton, New York, September 1997, BNL-52531, (1997).

T.M. SULLIVAN, J. HEISER, A. GARD, and G. SENUM, "Monitoring Subsurface Barrier Integrity Using Perfluorocarbon Tracers", ASCE Journal of Environmental Engineering, Vol. 124, No. 6, (1998).

T.W. D'OTTAVIO and R.N. DIETZ, "Radon Source Rate Measurements using Perfluorocarbon Tracers", Indoor Air '87, 4th International Conference on Indoor Air Quality and Climate, Berlin, Germany, (1987).

E.G. HORN, R.N. DIETZ, R.M. ALDOUS, G.A. LEADON, J.J. HONAN, and K.K. SEIFFERT, EPRI 1991 PCB Seminar, Baltimore, MD, Electric Power Research Institute (1991).

T. SULLIVAN, A.Q. ARMSTRONG, A.B. DINDAL, R.A. JENKINS, J. OSLEEB, and E.N. KOGLIN, "Environmental Technology Verification Report. Environmental Decision Support Software. C Tech Development Corporation, Environmental Visualization System (EVS)," EPA/600/R-00/047, (2000). 


\section{APPENDIX A: PFT DATA}

Abbreviations

NLIP $=$ North loop injection point

[samples the north secondary duct at the circulation pump]

SLIP $=$ South loop injection point

[samples the south secondary duct at the circulation pump]

NDBTC $=$ North duct bottom tracer concentration

[samples the north secondary duct at the bottom of the middle expansion joint]

SDBTC $=$ South duct bottom tracer concentration [samples the south secondary duct at the bottom of the middle expansion joint]

PSTC $=$ Pressure switch tracer concentration [samples the reactor pile at the pressure switch]

CDPTC $=$ Canal deep pit tracer concentration [samples the fuel canal deep pit]

NDPTC $=$ North duct primary tracer concentration [samples the north primary duct at the last expansion joint]

SDPTC $=$ South duct primary tracer concentration

[samples the south primary duct at the last expansion joint]

$\begin{array}{ll}\text { PDCB }= & \text { Perfluorodimethylcyclobutane } \\ \text { PMCH = } & \text { Perfluoromethylcyclohexane } \\ \text { o-PDCH = } & \text { Orthocisperfluorodimethylcyclohexane } \\ \text { PMCP }= & \text { Perfluoromethylcyclopentane }\end{array}$

All concentrations are in parts per billion

\begin{tabular}{|c|c|c|c|c|c|c|c|}
\hline Location & Port & Date & Time & PDCB & PMCH & o-PDCH & PMCP \\
\hline NLIP & & 31-Jan & $14: 05$ & 53.116 & 2.168 & & \\
\hline NLIP & & 31-Jan & $16: 29$ & 56.630 & 2.552 & & \\
\hline PSTC & & 31-Jan & $14: 12$ & 0.134 & 0.070 & & \\
\hline PSTC & & 31-Jan & $16: 35$ & 0.227 & 0.097 & & \\
\hline SLIP & 31-Jan & $14: 00$ & 0.210 & 44.603 & & \\
\hline SLIP & 31-Jan & $16: 23$ & 0.067 & 1.198 & & \\
\hline NLIP & 1-Feb & $15: 22$ & 60.241 & 11.898 & & \\
\hline PSTC & 1-Feb & $10: 28$ & 3.210 & 3.935 & & \\
\hline PSTC & 1-Feb & $15: 34$ & 0.414 & 0.296 & & \\
\hline SLIP & 1-Feb & $15: 15$ & 0.188 & 144.552 & & \\
\hline CDPTC & 2-Feb & $14: 30$ & 0.451 & 0.183 & & \\
\hline CDPTC & 2-Feb & $16: 36$ & 0.364 & 0.180 & & \\
\hline NDBTC & 2-Feb & $14: 10$ & 67.518 & 7.242 & & \\
\hline NDBTC & 2-Feb & $16: 26$ & 65.930 & 7.296 & & \\
\hline NDPTC & 2-Feb & $13: 50$ & 1.682 & 0.234 & & \\
\hline NDPTC & 2-Feb & $16: 32$ & 0.074 & 0.459 & & \\
\hline NLIP & 2-Feb & $11: 00$ & 74.589 & 6.657 & & \\
\hline NLIP & 2-Feb & $14: 20$ & 75.862 & 7.396 & & \\
\hline NLIP & 2-Feb & $16: 25$ & 86.954 & 7.815 & & \\
\hline PSTC & 2-Feb & $11: 10$ & 0.756 & 0.523 & & \\
\hline PSTC & 2-Feb & $14: 30$ & 0.760 & 0.107 & & \\
\hline PSTC & 2-Feb & $16: 39$ & 0.813 & 0.107 & & \\
\hline SDBTC & 2-Feb & $14: 12$ & 1.032 & 83.769 & & \\
\hline SDBTC & 2-Feb & $16: 24$ & 1.027 & 84.838 & & \\
\hline SDPTC & 2-Feb & $13: 50$ & 0.050 & 0.582 & & \\
\hline
\end{tabular}




\begin{tabular}{|c|c|c|c|c|c|c|c|}
\hline Location & Port & Date & Time & PDCB & $\mathrm{PMCH}$ & o-PDCH & PMCP \\
\hline SDPTC & & 2-Feb & $16: 30$ & 1.831 & 0.224 & & \\
\hline SLIP & & 2-Feb & $10: 55$ & 0.608 & 116.736 & & \\
\hline SLIP & & 2-Feb & $14: 20$ & 0.960 & 80.300 & & \\
\hline SLIP & & 2-Feb & $16: 23$ & 0.944 & 97.112 & & \\
\hline CDPTC & & $3-\mathrm{Feb}$ & $11: 13$ & 0.432 & 0.209 & & \\
\hline NDBTC & & $3-\mathrm{Feb}$ & 11:06 & 45.586 & 4.889 & & \\
\hline NDPTC & & 3-Feb & $10: 55$ & 1.349 & 0.198 & & \\
\hline NLIP & & $3-\mathrm{Feb}$ & $10: 50$ & 74.216 & 6.600 & & \\
\hline PSTC & & $3-\mathrm{Feb}$ & $11: 16$ & 1.214 & 0.161 & & \\
\hline SDBTC & & 3-Feb & 11:04 & 0.699 & 75.560 & & \\
\hline SDPTC & & $3-\mathrm{Feb}$ & $10: 58$ & 0.037 & 0.196 & & \\
\hline SLIP & & 3-Feb & $10: 45$ & 0.663 & 91.692 & & \\
\hline CDPTC & & 4-Feb & $11: 36$ & 0.519 & 0.169 & & \\
\hline NDBTC & & 4-Feb & 11:09 & 66.471 & 6.895 & & \\
\hline NDPTC & & 4-Feb & $11: 28$ & 1.436 & 0.206 & & \\
\hline NLIP & & 4-Feb & $11: 23$ & 73.093 & 7.169 & & \\
\hline PSTC & & 4-Feb & $11: 40$ & 1.116 & 0.150 & & \\
\hline SDBTC & & 4-Feb & $11: 12$ & 0.781 & 90.612 & & \\
\hline SDPTC & & 4-Feb & $11: 31$ & 0.070 & 0.217 & & \\
\hline SLIP & & 4-Feb & 11:19 & 0.729 & 90.944 & & \\
\hline CDPTC & & 5-Feb & 11:31 & 0.678 & 0.469 & & \\
\hline NDBTC & & 5-Feb & $11: 52$ & 69.421 & 12.323 & & \\
\hline NDPTC & & $5-\mathrm{Feb}$ & $11: 40$ & 2.963 & 0.425 & & \\
\hline NLIP & & 5-Feb & $11: 25$ & 87.678 & 11.779 & & \\
\hline PSTC & & 5-Feb & $11: 33$ & 1.342 & 0.218 & & \\
\hline SDBTC & & 5-Feb & $11: 50$ & 2.214 & 111.450 & & \\
\hline SDPTC & & 5-Feb & $11: 42$ & 0.106 & 0.937 & & \\
\hline SLIP & & 5-Feb & $11: 18$ & 1.886 & 131.977 & & \\
\hline 1 & $\mathrm{~S}$ & 6-Feb & 9:57 & 0.191 & 12.344 & 0.000 & 0.075 \\
\hline 1 & 1 & 6-Feb & 10:02 & 0.731 & 29.730 & & \\
\hline 1 & 2 & 6-Feb & 10:04 & 2.404 & 82.457 & & \\
\hline 1 & 3 & 6-Feb & $10: 00$ & 2.386 & 76.188 & & \\
\hline 1 & 4 & 6-Feb & 10:06 & 0.271 & 14.821 & & \\
\hline 2 & $\mathrm{~S}$ & 6-Feb & $11: 00$ & 0.129 & 0.198 & & \\
\hline 2 & 1 & 6-Feb & $\wedge$ & 0.032 & 0.550 & & \\
\hline 2 & 2 & 6-Feb & $\wedge$ & 0.122 & 5.383 & & \\
\hline 2 & 3 & 6-Feb & $\wedge$ & 0.791 & 24.754 & & \\
\hline 2 & 4 & 6-Feb & 11:08 & 1.751 & 21.244 & & \\
\hline 3 & $\mathrm{~S}$ & 6-Feb & $11: 10$ & 0.187 & 1.892 & & \\
\hline 3 & 1 & 6-Feb & $\wedge$ & 0.250 & 2.350 & & \\
\hline 3 & 2 & 6-Feb & $\wedge$ & 0.386 & 3.497 & & \\
\hline 3 & 3 & 6-Feb & $\wedge$ & 0.612 & 6.833 & & \\
\hline 3 & 4 & 6-Feb & $11: 16$ & 1.538 & 14.504 & & \\
\hline 4 & 1 & 6-Feb & $\wedge$ & 0.910 & 7.840 & & \\
\hline 4 & 2 & 6-Feb & $\wedge$ & 1.009 & 8.085 & & \\
\hline 4 & 3 & 6-Feb & $\wedge$ & 4.374 & 37.587 & & \\
\hline 4 & 4 & 6-Feb & $11: 35$ & 2.794 & 22.161 & & \\
\hline
\end{tabular}




\begin{tabular}{|c|c|c|c|c|c|c|c|}
\hline Location & Port & Date & Time & PDCB & $\mathrm{PMCH}$ & o-PDCH & PMCP \\
\hline 5 & $\mathrm{~S}$ & 6-Feb & $11: 59$ & 0.026 & 0.308 & 0.000 & 0.000 \\
\hline 5 & 1 & 6-Feb & 12:01 & 0.045 & 0.614 & 0.000 & 0.000 \\
\hline 5 & 2 & 6-Feb & $12: 03$ & 0.080 & 0.967 & & \\
\hline 5 & 3 & 6-Feb & 12:06 & 0.098 & 1.015 & 0.000 & 0.000 \\
\hline 5 & 4 & 6-Feb & $12: 07$ & 0.216 & 1.939 & 0.000 & 0.000 \\
\hline 6 & 1 & 6-Feb & 12:01 & 0.003 & 0.037 & 0.000 & 0.000 \\
\hline 6 & 2 & 6-Feb & $12: 02$ & 0.003 & 0.066 & 0.000 & 0.000 \\
\hline 6 & 3 & 6-Feb & $12: 04$ & 0.002 & 0.043 & 0.000 & 0.000 \\
\hline 6 & 4 & 6-Feb & $12: 05$ & 0.002 & 0.057 & 0.000 & 0.000 \\
\hline 7 & S & 6-Feb & $10: 25$ & 0.001 & 0.000 & 0.000 & 0.000 \\
\hline 7 & 1 & 6-Feb & $10: 36$ & 0.005 & 0.005 & 0.000 & 0.000 \\
\hline 7 & 2 & 6-Feb & $10: 38$ & 0.002 & 0.021 & & \\
\hline 7 & 3 & 6-Feb & $10: 40$ & 0.058 & 0.031 & 0.000 & 0.000 \\
\hline 7 & 4 & 6-Feb & $10: 48$ & 0.005 & 0.079 & & \\
\hline 8 & 1 & 6-Feb & $10: 24$ & 0.034 & 3.137 & 0.000 & 0.005 \\
\hline 8 & 2 & 6-Feb & $10: 45$ & 0.016 & 1.885 & 0.000 & 0.000 \\
\hline 8 & 3 & 6-Feb & $10: 46$ & 0.001 & 0.182 & 0.000 & 0.000 \\
\hline 9 & 1 & 6-Feb & $11: 04$ & 0.003 & 0.000 & 0.000 & 0.000 \\
\hline 9 & 2 & 6-Feb & 11:07 & 0.002 & 0.012 & & \\
\hline 9 & 3 & 6-Feb & 11:09 & 0.000 & 0.000 & 0.000 & 0.000 \\
\hline 9 & 4 & 6-Feb & $11: 12$ & 0.002 & 0.098 & 0.000 & 0.000 \\
\hline 10 & 1 & 6-Feb & $10: 59$ & 0.000 & 0.021 & & \\
\hline 10 & 2 & 6-Feb & 11:01 & 0.000 & 0.012 & 0.000 & 0.000 \\
\hline 10 & 3 & 6-Feb & $11: 02$ & 0.000 & 0.038 & 0.000 & 0.000 \\
\hline 10 & 4 & 6-Feb & 11:04 & 0.261 & 6.964 & 0.000 & 0.023 \\
\hline 11 & 1 & 6-Feb & $11: 10$ & 0.025 & 0.041 & & \\
\hline 11 & 2 & 6-Feb & $11: 12$ & 0.389 & 0.256 & 0.000 & 0.000 \\
\hline 11 & 3 & 6-Feb & $11: 14$ & 3.059 & 2.379 & & \\
\hline 11 & 4 & 6-Feb & $11: 15$ & 8.579 & 5.488 & & \\
\hline 12 & 1 & 6-Feb & $11: 19$ & 0.350 & 0.467 & 0.000 & 0.000 \\
\hline 12 & 2 & 6-Feb & $11: 21$ & 0.135 & 0.073 & 0.000 & 0.000 \\
\hline 12 & 3 & 6-Feb & $11: 22$ & 1.202 & 9.484 & & \\
\hline 12 & 4 & 6-Feb & $11: 24$ & 3.674 & 5.184 & 0.000 & 0.000 \\
\hline 13 & 1 & 6-Feb & $11: 19$ & 0.027 & 0.069 & 0.000 & 0.000 \\
\hline 13 & 2 & 6-Feb & $11: 21$ & 0.032 & 0.042 & & \\
\hline 13 & 3 & 6-Feb & $11: 22$ & 0.149 & 0.161 & 0.000 & 0.020 \\
\hline 13 & 4 & 6-Feb & $11: 24$ & 0.219 & 0.546 & & \\
\hline 14 & 2 & 6-Feb & $11: 34$ & 0.003 & 0.010 & 0.000 & 0.000 \\
\hline 14 & 3 & 6-Feb & $11: 36$ & 0.019 & 0.067 & 0.000 & 0.000 \\
\hline 14 & 4 & 6-Feb & $11: 37$ & 0.078 & 0.254 & 0.000 & 0.000 \\
\hline 15 & 2 & 6-Feb & $11: 45$ & 0.000 & 0.000 & 0.000 & 0.000 \\
\hline 15 & 3 & 6-Feb & $11: 46$ & 0.000 & 0.000 & 0.000 & 0.000 \\
\hline 15 & 4 & 6-Feb & $11: 47$ & 0.005 & 0.058 & 0.003 & 0.000 \\
\hline 16 & S & 6-Feb & $11: 42$ & 0.083 & 0.063 & & \\
\hline 16 & 1 & 6-Feb & $\wedge$ & 13.833 & 2.369 & 0.000 & 0.000 \\
\hline 16 & 2 & 6-Feb & $\wedge$ & 12.190 & 2.125 & & \\
\hline 16 & 3 & 6-Feb & $\wedge$ & 38.085 & 9.896 & 0.000 & 0.000 \\
\hline
\end{tabular}




\begin{tabular}{|c|c|c|c|c|c|c|c|}
\hline Location & Port & Date & Time & PDCB & $\mathrm{PMCH}$ & o-PDCH & PMCP \\
\hline 16 & 4 & 6-Feb & $11: 52$ & 14.948 & 9.333 & & \\
\hline 17 & $\mathrm{~S}$ & 6-Feb & $11: 55$ & 0.105 & 0.368 & & \\
\hline 17 & 1 & 6-Feb & $\wedge$ & 0.915 & 5.047 & & \\
\hline 17 & 3 & 6-Feb & $\wedge$ & 13.333 & 23.141 & & \\
\hline 17 & 4 & 6-Feb & $12: 06$ & 6.096 & 14.838 & 0.000 & 0.000 \\
\hline 18 & S & 6-Feb & $14: 00$ & 4.171 & 22.087 & & \\
\hline 18 & 1 & 6-Feb & $\wedge$ & 7.258 & 40.372 & 0.000 & 0.000 \\
\hline 18 & 2 & 6-Feb & $\wedge$ & 7.306 & 48.543 & 0.000 & 0.000 \\
\hline 18 & 3 & 6-Feb & $\wedge$ & 7.536 & 48.283 & 0.000 & 0.000 \\
\hline 18 & 4 & 6-Feb & $14: 08$ & 6.908 & 54.227 & 0.000 & 0.000 \\
\hline 19 & 1 & 6-Feb & $14: 03$ & 16.186 & 39.494 & 0.000 & 0.000 \\
\hline 19 & 2 & 6-Feb & 14:04 & 6.657 & 21.368 & 0.000 & 0.000 \\
\hline 19 & 3 & 6-Feb & $14: 06$ & 7.648 & 76.241 & 0.002 & 0.000 \\
\hline 19 & 4 & 6-Feb & $14: 07$ & 9.701 & 78.717 & 0.000 & 0.000 \\
\hline 20 & $S$ & 6-Feb & $14: 10$ & 0.204 & 1.422 & 0.000 & 0.000 \\
\hline 20 & 1 & 6-Feb & $\wedge$ & 29.191 & 18.464 & 0.000 & 0.000 \\
\hline 20 & 2 & 6-Feb & $\wedge$ & 14.218 & 31.356 & 0.000 & 0.000 \\
\hline 20 & 3 & 6-Feb & $\wedge$ & 8.609 & 74.421 & 0.000 & 0.000 \\
\hline 21 & $\mathrm{~S}$ & 6-Feb & $14: 06$ & 1.533 & 0.829 & 0.000 & 0.000 \\
\hline 21 & 1 & 6-Feb & 14:11 & 0.095 & 0.109 & 0.000 & 0.000 \\
\hline 21 & 2 & 6-Feb & $14: 21$ & 3.357 & 1.714 & 0.000 & 0.000 \\
\hline 21 & 3 & 6-Feb & $14: 28$ & 27.581 & 10.093 & 0.000 & 0.000 \\
\hline 21 & 4 & 6-Feb & $14: 30$ & 12.106 & 4.414 & 0.000 & 0.000 \\
\hline 22 & $S$ & 6-Feb & $14: 15$ & 0.551 & 0.587 & 0.000 & 0.000 \\
\hline 22 & 1 & 6-Feb & $14: 18$ & 0.095 & 0.109 & 0.000 & 0.000 \\
\hline 22 & 2 & 6-Feb & $14: 20$ & 29.726 & 15.624 & 0.000 & 0.000 \\
\hline 22 & 3 & 6-Feb & $14: 21$ & 41.229 & 17.329 & 0.000 & 0.000 \\
\hline 22 & 4 & 6-Feb & $14: 22$ & 36.357 & 14.888 & 0.000 & 0.000 \\
\hline 23 & 1 & 6-Feb & $14: 28$ & 0.063 & 0.134 & 0.000 & 0.000 \\
\hline 23 & 2 & 6-Feb & $14: 30$ & 28.078 & 13.487 & 0.000 & 0.000 \\
\hline 23 & 3 & 6-Feb & $14: 32$ & 25.925 & 12.487 & 0.000 & 0.000 \\
\hline 23 & 4 & 6-Feb & $14: 33$ & 35.110 & 15.551 & 0.000 & 0.000 \\
\hline 24 & 1 & 6-Feb & $14: 39$ & 0.013 & 0.014 & 0.000 & 0.000 \\
\hline 24 & 2 & 6-Feb & $14: 41$ & 22.697 & 11.781 & 0.000 & 0.000 \\
\hline 24 & 3 & 6-Feb & $14: 42$ & 21.957 & 9.735 & 0.000 & 0.000 \\
\hline 24 & 4 & 6-Feb & $14: 43$ & 24.399 & 11.047 & 0.000 & 0.000 \\
\hline 25 & 1 & 6-Feb & $14: 37$ & 0.151 & 0.189 & 0.000 & 0.000 \\
\hline 25 & 2 & 6-Feb & $14: 39$ & 1.410 & 0.733 & 0.000 & 0.000 \\
\hline 25 & 3 & 6-Feb & $14: 41$ & 11.677 & 21.599 & 0.000 & 0.000 \\
\hline 25 & 4 & 6-Feb & $14: 43$ & 14.262 & 35.776 & 0.000 & 0.000 \\
\hline 26 & 1 & 6-Feb & $14: 23$ & 0.034 & 0.222 & 0.000 & 0.000 \\
\hline 27 & 1 & 6-Feb & $14: 26$ & 0.100 & 0.861 & 0.000 & 0.000 \\
\hline 28 & 1 & 6-Feb & $14: 32$ & 0.146 & 1.395 & 0.000 & 0.000 \\
\hline 30 & 1 & 6-Feb & $15: 10$ & 0.231 & 0.285 & 0.000 & 0.000 \\
\hline 33 & 1 & 6-Feb & $14: 55$ & 0.141 & 0.172 & 0.000 & 0.000 \\
\hline 35 & 1 & 6-Feb & $14: 44$ & 0.008 & 0.138 & 0.000 & 0.000 \\
\hline 36 & 1 & 6-Feb & $14: 38$ & 0.204 & 1.354 & 0.000 & 0.000 \\
\hline
\end{tabular}




\begin{tabular}{|c|c|c|c|c|c|c|c|}
\hline Location & Port & Date & Time & PDCB & $\mathrm{PMCH}$ & o-PDCH & PMCP \\
\hline 37 & 1 & 6-Feb & $14: 35$ & 0.308 & 2.578 & 0.000 & 0.000 \\
\hline 39 & 1 & 6-Feb & $15: 21$ & 0.189 & 0.242 & 0.000 & 0.000 \\
\hline 40 & 1 & 6-Feb & $14: 58$ & 0.069 & 0.125 & 0.000 & 0.000 \\
\hline 42 & 1 & $6-\mathrm{Feb}$ & $11: 35$ & 0.002 & 0.014 & & \\
\hline 42 & 2 & 6-Feb & $11: 37$ & 0.002 & 0.021 & & \\
\hline 42 & 3 & 6-Feb & $11: 38$ & 2.056 & 5.733 & & \\
\hline 42 & 4 & 6-Feb & $11: 40$ & 8.049 & 24.288 & & \\
\hline CDPTC & & 6-Feb & $15: 20$ & 0.769 & 0.830 & & \\
\hline NDBTC & & 6-Feb & $15: 40$ & 382.300 & 85.100 & & \\
\hline NDPTC & & 6-Feb & $15: 00$ & 1.712 & 0.357 & & \\
\hline NLIP & & 6-Feb & $10: 30$ & 53.000 & 8.650 & & \\
\hline NLIP & & 6-Feb & $15: 05$ & 40.700 & 8.930 & & \\
\hline PSTC & & 6-Feb & $15: 15$ & 1.857 & 0.547 & & \\
\hline SDBTC & & 6-Feb & $15: 38$ & 2.730 & 53.300 & & \\
\hline SDPTC & & 6-Feb & $15: 02$ & 0.070 & 0.717 & & \\
\hline SLIP & & 6-Feb & $10: 30$ & 0.192 & 7.171 & 0.000 & 0.020 \\
\hline SLIP & & 6-Feb & $15: 10$ & 1.700 & 59.500 & & \\
\hline CDPTC & & 7-Feb & $11: 45$ & 0.448 & 0.417 & 0.000 & 0.725 \\
\hline CDPTC & & 7-Feb & $16: 03$ & 0.409 & 0.292 & 0.000 & 0.000 \\
\hline NDBTC & & 7-Feb & $11: 35$ & 11.242 & 5.800 & 0.000 & 24.513 \\
\hline NDBTC & & 7-Feb & $15: 55$ & 8.914 & 5.363 & 0.000 & 63.283 \\
\hline NDPTC & & 7-Feb & $11: 40$ & 0.852 & 0.271 & 0.000 & 2.222 \\
\hline NDPTC & & 7-Feb & $15: 59$ & 0.715 & 0.223 & 0.000 & 2.219 \\
\hline NLIP & & 7-Feb & $11: 30$ & 9.800 & 6.200 & 0.000 & 323.000 \\
\hline NLIP & & 7-Feb & $15: 54$ & 8.193 & 5.905 & 0.000 & 325.187 \\
\hline PSTC & & 7-Feb & $11: 47$ & 1.191 & 0.295 & 0.000 & 0.350 \\
\hline PSTC & & 7-Feb & 16:07 & 1.092 & 0.248 & 0.000 & 0.000 \\
\hline SDBTC & & 7-Feb & $11: 35$ & 0.744 & 23.173 & 0.000 & 1.428 \\
\hline SDBTC & & 7-Feb & $15: 53$ & 0.615 & 19.602 & 0.000 & 2.504 \\
\hline SDPTC & & 7-Feb & $11: 40$ & 0.027 & 0.322 & 0.000 & 1.510 \\
\hline SDPTC & & 7-Feb & 16:01 & 0.018 & 0.235 & 0.000 & 1.352 \\
\hline SLIP & & 7-Feb & $11: 30$ & 0.000 & 27.400 & 0.000 & 275.700 \\
\hline SLIP & & 7-Feb & $15: 50$ & 0.000 & 20.532 & 0.000 & 341.136 \\
\hline 1 & 4 & 8-Feb & $9: 23$ & 0.654 & 23.624 & & 0.110 \\
\hline 2 & 4 & 8-Feb & $9: 26$ & 1.248 & 17.227 & & 0.735 \\
\hline 3 & 4 & 8-Feb & $9: 29$ & 1.136 & 12.694 & & 0.818 \\
\hline 4 & 4 & 8-Feb & $9: 33$ & 1.885 & 20.736 & & 1.934 \\
\hline 5 & 4 & $8-\mathrm{Feb}$ & $9: 37$ & 0.326 & 3.287 & 0.000 & 0.023 \\
\hline 6 & 4 & 8-Feb & $9: 41$ & 0.005 & 0.158 & 0.000 & 0.005 \\
\hline 7 & 4 & 8-Feb & $9: 46$ & 0.012 & 0.393 & 0.000 & 0.016 \\
\hline 8 & 3 & 8-Feb & $10: 03$ & 0.007 & 0.222 & 0.000 & 0.019 \\
\hline 9 & 4 & 8-Feb & $10: 08$ & 0.006 & 0.086 & 0.000 & 0.005 \\
\hline 10 & 4 & 8-Feb & $10: 13$ & 0.080 & 2.416 & 0.000 & 0.243 \\
\hline 11 & 4 & 8-Feb & $10: 21$ & 7.448 & 8.764 & 0.000 & 6.168 \\
\hline 12 & 4 & 8-Feb & $10: 24$ & 3.779 & 10.020 & 0.000 & 2.239 \\
\hline 13 & 4 & $8-\mathrm{Feb}$ & $10: 28$ & 0.614 & 1.370 & 0.000 & 0.000 \\
\hline 14 & 4 & 8-Feb & $10: 34$ & 0.137 & 0.319 & 0.000 & 0.000 \\
\hline
\end{tabular}




\begin{tabular}{|c|c|c|c|c|c|c|c|}
\hline Location & Port & Date & Time & PDCB & $\mathrm{PMCH}$ & o-PDCH & PMCP \\
\hline 15 & 4 & 8 -Feb & $10: 37$ & 0.004 & 0.056 & & 0.009 \\
\hline 16 & 4 & 8-Feb & $9: 22$ & 17.203 & 9.197 & & 2.545 \\
\hline 17 & 4 & 8-Feb & $9: 29$ & 7.207 & 26.319 & & 3.758 \\
\hline 18 & 4 & 8-Feb & $9: 33$ & 7.098 & 57.371 & & 0.000 \\
\hline 19 & 4 & 8-Feb & 9:37 & 1.937 & 21.259 & & 7.210 \\
\hline 20 & 3 & 8-Feb & $14: 33$ & 1.390 & 12.202 & 0.000 & 12.001 \\
\hline 21 & 3 & 8-Feb & $14: 40$ & 18.226 & 11.881 & 0.000 & 15.652 \\
\hline 21 & 4 & 8-Feb & $9: 53$ & 10.337 & 6.783 & 0.000 & 2.198 \\
\hline 22 & 4 & 8-Feb & $9: 57$ & 20.284 & 11.423 & 0.000 & 6.849 \\
\hline 23 & 4 & $8-\mathrm{Feb}$ & $10: 00$ & 17.515 & 11.518 & 0.000 & 3.578 \\
\hline 24 & 4 & 8-Feb & 10:04 & 27.117 & 13.294 & 0.000 & 0.000 \\
\hline 25 & 4 & 8-Feb & 10:08 & 3.150 & 10.032 & 0.000 & 14.652 \\
\hline 26 & 1 & 8-Feb & $10: 15$ & 0.025 & 0.146 & 0.000 & 0.042 \\
\hline 27 & 1 & 8-Feb & $10: 20$ & 0.059 & 0.512 & 0.000 & 0.041 \\
\hline 28 & 1 & $8-\mathrm{Feb}$ & $10: 23$ & 0.173 & 1.774 & 0.000 & 0.049 \\
\hline 29 & 1 & 8-Feb & $10: 27$ & 0.022 & 0.131 & 0.000 & 0.022 \\
\hline 33 & 1 & $8-\mathrm{Feb}$ & $11: 25$ & 0.002 & 0.010 & & 0.002 \\
\hline 35 & 1 & $8-\mathrm{Feb}$ & $10: 33$ & 0.010 & 0.051 & & 0.010 \\
\hline 36 & 1 & 8-Feb & $10: 41$ & 0.170 & 0.618 & 0.000 & 0.130 \\
\hline 37 & 1 & 8-Feb & $10: 45$ & 0.028 & 0.176 & 0.000 & 0.020 \\
\hline 40 & 1 & 8-Feb & $11: 23$ & 0.003 & 0.022 & 0.000 & 0.003 \\
\hline 41 & 1 & 8-Feb & $11: 10$ & 0.057 & 0.363 & 0.000 & 0.041 \\
\hline 42 & 4 & 8-Feb & $10: 41$ & 3.280 & 12.584 & & 5.832 \\
\hline CDPTC & & 8-Feb & $11: 45$ & 0.251 & 0.153 & & 0.750 \\
\hline NDBTC & & 8-Feb & $11: 16$ & 2.695 & 6.453 & 0.000 & 86.059 \\
\hline NDPTC & & 8-Feb & $11: 39$ & 0.350 & 0.150 & & 2.359 \\
\hline NLIP & & 8-Feb & $11: 33$ & 2.867 & 3.546 & 0.000 & 294.650 \\
\hline PSTC & & 8-Feb & $11: 47$ & 0.561 & 0.163 & & 0.738 \\
\hline SDBTC & & 8-Feb & $11: 13$ & 0.652 & 9.302 & 0.000 & 11.086 \\
\hline SDPTC & & 8-Feb & $11: 38$ & 0.016 & 0.139 & & 1.311 \\
\hline SLIP & & 8-Feb & $11: 26$ & 0.000 & 10.347 & 0.000 & 74.838 \\
\hline 1 & $\mathrm{~S}$ & 9-Feb & $14: 35$ & 0.266 & 9.252 & 0.000 & 1.186 \\
\hline 1 & 1 & 9-Feb & $\wedge$ & 0.309 & 11.521 & 0.00 & 2.033 \\
\hline 1 & 2 & 9-Feb & $\wedge$ & 0.316 & 10.208 & 0.000 & 9.650 \\
\hline 1 & 3 & 9-Feb & $\wedge$ & 0.379 & 12.815 & 0.000 & 3.018 \\
\hline 1 & 4 & 9-Feb & $14: 48$ & 0.611 & 13.320 & 0.000 & 1.263 \\
\hline 2 & $\mathrm{~S}$ & 9-Feb & $14: 51$ & 0.000 & 0.270 & 0.000 & 0.849 \\
\hline 2 & 1 & 9-Feb & $\wedge$ & 0.050 & 1.133 & 0.000 & 0.196 \\
\hline 2 & 2 & 9-Feb & $\wedge$ & 0.217 & 6.304 & 0.000 & 0.266 \\
\hline 2 & 3 & 9-Feb & $\wedge$ & 0.661 & 14.938 & 0.000 & 2.008 \\
\hline 2 & 4 & 9-Feb & $14: 58$ & 1.077 & 13.939 & 0.000 & 1.289 \\
\hline 3 & 1 & 9-Feb & $\wedge$ & 0.402 & 3.886 & 0.000 & 0.106 \\
\hline 3 & 2 & 9-Feb & $\wedge$ & 0.579 & 5.913 & 0.000 & 0.104 \\
\hline 3 & 3 & 9-Feb & $\wedge$ & 0.787 & 8.694 & 0.000 & 0.511 \\
\hline 3 & 4 & 9-Feb & $15: 28$ & 1.032 & 11.556 & 0.000 & 1.113 \\
\hline 4 & 1 & $9-\mathrm{Feb}$ & $\wedge$ & 0.023 & 0.255 & 0.000 & 0.070 \\
\hline 4 & 2 & 9-Feb & $\wedge$ & 0.522 & 5.460 & 0.000 & 0.265 \\
\hline
\end{tabular}




\begin{tabular}{|c|c|c|c|c|c|c|c|}
\hline Location & Port & Date & Time & PDCB & $\mathrm{PMCH}$ & o-PDCH & PMCP \\
\hline 4 & 4 & 9-Feb & $15: 45$ & 1.177 & 11.842 & 0.000 & 1.320 \\
\hline 5 & $\mathrm{~S}$ & 9-Feb & $15: 48$ & 0.006 & 0.219 & 0.000 & 0.130 \\
\hline 5 & 1 & 9-Feb & $\wedge$ & 0.102 & 1.276 & 0.000 & 0.101 \\
\hline 5 & 2 & 9-Feb & $\wedge$ & 0.210 & 2.261 & 0.000 & 0.108 \\
\hline 5 & 3 & 9-Feb & $\wedge$ & 0.326 & 3.318 & 0.000 & 0.241 \\
\hline 5 & 4 & 9-Feb & 16:01 & 0.379 & 3.975 & 0.000 & 0.184 \\
\hline 6 & 1 & 9-Feb & $14: 51$ & 0.004 & 0.083 & 0.000 & 0.000 \\
\hline 7 & S & 9-Feb & $14: 09$ & 0.000 & 0.000 & 0.000 & 0.000 \\
\hline 7 & 1 & 9-Feb & $14: 13$ & 0.000 & 0.000 & 0.000 & 0.000 \\
\hline 7 & 2 & 9-Feb & $14: 20$ & 0.001 & 0.013 & 0.000 & 0.004 \\
\hline 9 & 1 & 9-Feb & $11: 22$ & 0.019 & 0.125 & 0.000 & 0.024 \\
\hline 9 & 2 & 9-Feb & $11: 28$ & 0.003 & 0.019 & 0.000 & 0.003 \\
\hline 9 & 4 & 9-Feb & $11: 37$ & 0.006 & 0.100 & 0.000 & 0.003 \\
\hline 10 & 1 & 9-Feb & 11:01 & 0.027 & 0.142 & 0.000 & 0.035 \\
\hline 10 & 2 & 9-Feb & $11: 04$ & 0.014 & 0.073 & 0.000 & 0.018 \\
\hline 11 & 1 & 9-Feb & $10: 47$ & 0.044 & 0.254 & 0.000 & 0.039 \\
\hline 11 & 2 & 9-Feb & $10: 50$ & 0.462 & 0.449 & 0.000 & 0.083 \\
\hline 11 & 3 & 9-Feb & $10: 54$ & 2.327 & 3.146 & 0.000 & 2.198 \\
\hline 11 & 4 & 9-Feb & $10: 58$ & 3.563 & 5.681 & 0.000 & 3.773 \\
\hline 12 & 1 & 9-Feb & $10: 32$ & 0.425 & 0.475 & 0.000 & 0.000 \\
\hline 12 & 2 & 9-Feb & $10: 36$ & 0.011 & 0.023 & 0.000 & 0.040 \\
\hline 12 & 3 & 9-Feb & $10: 39$ & 0.758 & 4.807 & 0.000 & 0.326 \\
\hline 12 & 4 & 9-Feb & $10: 41$ & 2.835 & 6.517 & 0.000 & 2.449 \\
\hline 13 & 1 & 9-Feb & $10: 05$ & 0.000 & 0.000 & 0.000 & 0.000 \\
\hline 13 & 4 & 9-Feb & $10: 22$ & 0.502 & 1.265 & 0.000 & 0.054 \\
\hline 14 & 2 & 9-Feb & $9: 47$ & 0.000 & 0.007 & 0.000 & 0.000 \\
\hline 14 & 3 & 9-Feb & $9: 50$ & 0.062 & 0.063 & 0.000 & 0.024 \\
\hline 15 & 2 & 9-Feb & $9: 33$ & 0.004 & 0.030 & 0.000 & 0.008 \\
\hline 15 & 3 & 9-Feb & $9: 36$ & 0.002 & 0.016 & 0.000 & 0.004 \\
\hline 15 & 4 & 9-Feb & $9: 40$ & 0.010 & 0.080 & 0.000 & 0.005 \\
\hline 16 & $S$ & 9-Feb & $15: 41$ & 0.064 & 0.681 & 0.000 & 0.251 \\
\hline 16 & 1 & 9-Feb & $15: 47$ & 1.957 & 1.609 & 0.000 & 13.660 \\
\hline 16 & 2 & 9-Feb & $15: 53$ & 5.903 & 4.368 & 0.000 & 6.893 \\
\hline 16 & 4 & 9-Feb & $16: 05$ & 10.185 & 10.216 & 0.000 & 7.538 \\
\hline 17 & S & 9-Feb & $15: 02$ & 0.101 & 1.613 & 0.000 & 0.059 \\
\hline 17 & 1 & 9-Feb & $15: 10$ & 0.731 & 4.607 & 0.000 & 0.082 \\
\hline 17 & 2 & 9-Feb & $15: 16$ & 0.084 & 1.193 & 0.000 & 0.054 \\
\hline 17 & 3 & 9-Feb & $15: 23$ & 5.631 & 29.315 & 0.000 & 21.142 \\
\hline 18 & S & 9-Feb & $14: 35$ & 2.827 & 15.126 & 0.000 & 0.753 \\
\hline 18 & 1 & 9-Feb & $14: 40$ & 6.335 & 30.905 & 0.000 & 1.212 \\
\hline 18 & 2 & 9-Feb & $14: 45$ & 4.583 & 33.216 & 0.000 & 2.799 \\
\hline 18 & 3 & 9-Feb & $14: 50$ & 3.201 & 30.055 & 0.000 & 4.758 \\
\hline 18 & 4 & 9-Feb & $14: 55$ & 4.812 & 44.475 & 0.000 & 1.968 \\
\hline 19 & 1 & 9-Feb & $14: 16$ & 0.178 & 0.671 & 0.000 & 4.281 \\
\hline 19 & 2 & 9-Feb & $14: 21$ & 0.838 & 4.031 & 0.000 & 18.796 \\
\hline 19 & 3 & 9-Feb & $14: 25$ & 0.337 & 3.809 & 0.000 & 15.211 \\
\hline 19 & 4 & 9-Feb & $14: 29$ & 2.127 & 12.898 & 0.000 & 11.760 \\
\hline
\end{tabular}




\begin{tabular}{|c|c|c|c|c|c|c|c|}
\hline Location & Port & Date & Time & PDCB & $\mathrm{PMCH}$ & o-PDCH & PMCP \\
\hline 20 & 1 & 9-Feb & $11: 26$ & 0.650 & 1.373 & 0.000 & 37.839 \\
\hline 20 & 2 & 9-Feb & $11: 29$ & 4.117 & 9.119 & 0.000 & 27.496 \\
\hline 20 & 3 & 9-Feb & $11: 35$ & 1.032 & 6.730 & 0.000 & 14.197 \\
\hline 21 & S & 9-Feb & $10: 44$ & 0.144 & 0.281 & 0.000 & 0.733 \\
\hline 21 & 1 & 9-Feb & $10: 52$ & 0.685 & 1.060 & 0.000 & 3.432 \\
\hline 21 & 2 & 9-Feb & $10: 58$ & 0.561 & 0.754 & 0.000 & 2.225 \\
\hline 21 & 3 & 9-Feb & 11:04 & 12.608 & 8.830 & 0.000 & 34.024 \\
\hline 21 & 4 & 9-Feb & $11: 10$ & 2.391 & 2.056 & 0.000 & 6.202 \\
\hline 22 & 1 & 9-Feb & $10: 20$ & 1.131 & 2.045 & 0.000 & 63.464 \\
\hline 22 & 2 & 9-Feb & $10: 26$ & 5.220 & 5.229 & 0.000 & 61.175 \\
\hline 22 & 3 & 9-Feb & $10: 32$ & 6.792 & 5.830 & 0.000 & 59.510 \\
\hline 22 & 4 & 9-Feb & $10: 38$ & 13.270 & 7.538 & 0.000 & 32.539 \\
\hline 23 & 1 & 9-Feb & $9: 52$ & 0.334 & 0.442 & 0.000 & 0.132 \\
\hline 23 & 2 & 9-Feb & $9: 56$ & 3.912 & 4.212 & 0.000 & 49.353 \\
\hline 23 & 3 & 9-Feb & $9: 59$ & 7.641 & 6.695 & 0.000 & 36.797 \\
\hline 23 & 4 & 9-Feb & 10:02 & 10.539 & 7.911 & 0.000 & 32.818 \\
\hline 24 & 1 & 9-Feb & $9: 38$ & 0.015 & 0.199 & 0.000 & 0.417 \\
\hline 24 & 2 & 9-Feb & $9: 41$ & 3.501 & 3.840 & 0.000 & 46.869 \\
\hline 24 & 3 & 9-Feb & $9: 44$ & 10.860 & 6.753 & 0.000 & 7.496 \\
\hline 24 & 4 & 9-Feb & $9: 47$ & 19.858 & 9.081 & 0.000 & 0.000 \\
\hline 25 & 4 & 9-Feb & $9: 32$ & 0.000 & 0.000 & 0.000 & 0.001 \\
\hline 26 & 1 & 9-Feb & 16:04 & 0.005 & 0.137 & 0.000 & 0.052 \\
\hline 28 & 1 & 9-Feb & $16: 08$ & 0.135 & 1.460 & 0.000 & 0.119 \\
\hline 33 & 1 & 9-Feb & $16: 21$ & 0.014 & 0.064 & 0.000 & 0.017 \\
\hline 35 & 1 & 9-Feb & $16: 10$ & 0.006 & 0.061 & 0.000 & 0.039 \\
\hline 37 & 1 & 9-Feb & $16: 20$ & 0.405 & 3.603 & 0.000 & 0.045 \\
\hline 40 & 1 & 9-Feb & $16: 19$ & 0.000 & 0.003 & 0.000 & 0.000 \\
\hline 42 & 2 & 9-Feb & $9: 16$ & 0.000 & 0.000 & 0.000 & 0.000 \\
\hline 42 & 3 & 9-Feb & $9: 19$ & 0.218 & 0.981 & 0.000 & 0.495 \\
\hline CDPTC & & 9-Feb & $14: 23$ & 0.119 & 0.121 & 0.000 & 2.934 \\
\hline NDBTC & & 9-Feb & $15: 22$ & 0.000 & 3.370 & 0.000 & 202.000 \\
\hline NDPTC & & 9-Feb & 14:05 & 0.166 & 0.136 & 0.000 & 7.329 \\
\hline NLIP & & 9-Feb & $14: 15$ & 0.000 & 3.100 & 0.000 & 384.000 \\
\hline PSTC & & 9-Feb & $14: 27$ & 0.305 & 0.127 & 0.000 & 3.578 \\
\hline SDBTC & & 9-Feb & $15: 18$ & 0.360 & 5.800 & 0.000 & 26.700 \\
\hline SDPTC & & 9-Feb & 14:07 & 0.014 & 0.089 & 0.000 & 0.296 \\
\hline SLIP & & 9-Feb & $14: 19$ & 0.000 & 6.800 & 0.000 & 121.000 \\
\hline 1 & $\mathrm{~S}$ & 10-Feb & $10: 00$ & 0.039 & 1.535 & 0.000 & 0.074 \\
\hline 1 & S & 10-Feb & $\wedge$ & 0.039 & 1.535 & 0.000 & 0.074 \\
\hline 1 & 1 & 10-Feb & $\wedge$ & 0.235 & 8.029 & 0.000 & 0.852 \\
\hline 1 & 2 & 10-Feb & $\wedge$ & 0.198 & 5.042 & 0.000 & 15.272 \\
\hline 1 & 3 & 10-Feb & $\wedge$ & 0.172 & 5.706 & 0.000 & 1.562 \\
\hline 1 & 4 & 10-Feb & $10: 10$ & 0.411 & 12.500 & 0.000 & 0.244 \\
\hline 2 & $\mathrm{~S}$ & 10-Feb & $9: 25$ & 0.017 & 0.301 & 0.000 & 0.000 \\
\hline 2 & 1 & $10-\mathrm{Feb}$ & $\wedge$ & 0.055 & 1.379 & 0.000 & 0.000 \\
\hline 2 & 2 & 10-Feb & $\wedge$ & 0.226 & 5.857 & 0.000 & 0.114 \\
\hline 2 & 3 & 10-Feb & $\wedge$ & 0.631 & 13.891 & 0.000 & 0.910 \\
\hline
\end{tabular}




\begin{tabular}{|c|c|c|c|c|c|c|c|}
\hline Location & Port & Date & Time & PDCB & $\mathrm{PMCH}$ & o-PDCH & PMCP \\
\hline 2 & 4 & $10-\mathrm{Feb}$ & $9: 50$ & 0.801 & 10.788 & 0.000 & 0.898 \\
\hline 3 & $\mathrm{~S}$ & $10-\mathrm{Feb}$ & $9: 10$ & 0.196 & 2.094 & 0.000 & 0.034 \\
\hline 3 & 1 & $10-\mathrm{Feb}$ & $\wedge$ & 0.377 & 3.598 & 0.000 & 0.040 \\
\hline 3 & 2 & 10-Feb & $\wedge$ & 0.640 & 5.526 & 0.000 & 0.000 \\
\hline 3 & 3 & 10-Feb & $\wedge$ & 0.742 & 7.839 & 0.000 & 0.419 \\
\hline 3 & 4 & 10-Feb & $9: 20$ & 0.800 & 8.816 & 0.000 & 0.748 \\
\hline 4 & 1 & 10-Feb & $\wedge$ & 0.002 & 0.024 & 0.000 & 0.003 \\
\hline 4 & 2 & 10-Feb & $\wedge$ & 0.275 & 2.891 & 0.000 & 0.114 \\
\hline 4 & 3 & $10-\mathrm{Feb}$ & $\wedge$ & 0.798 & 7.665 & 0.000 & 0.257 \\
\hline 4 & 4 & 10-Feb & 9:07 & 0.678 & 6.909 & 0.000 & 0.980 \\
\hline 5 & S & 10-Feb & $10: 12$ & 0.022 & 0.300 & 0.000 & 0.027 \\
\hline 5 & 1 & 10-Feb & $\wedge$ & 0.055 & 0.712 & 0.000 & 0.052 \\
\hline 5 & 2 & 10-Feb & $\wedge$ & 0.115 & 1.374 & 0.000 & 0.048 \\
\hline 5 & 3 & 10-Feb & $\wedge$ & 0.264 & 2.681 & 0.000 & 0.138 \\
\hline 5 & 4 & 10-Feb & $10: 17$ & 0.286 & 2.944 & 0.000 & 0.112 \\
\hline 6 & S & 10-Feb & $11: 15$ & 0.008 & 0.114 & 0.000 & 0.025 \\
\hline 6 & 1 & 10-Feb & $11: 17$ & 0.005 & 0.092 & 0.000 & 0.008 \\
\hline 6 & 2 & 10-Feb & $11: 20$ & 0.008 & 0.153 & 0.000 & 0.025 \\
\hline 6 & 3 & 10-Feb & $11: 25$ & 0.007 & 0.082 & 0.000 & 0.077 \\
\hline 6 & 4 & 10-Feb & $11: 29$ & 0.005 & 0.066 & 0.000 & 0.028 \\
\hline 7 & S & 10-Feb & $11: 14$ & 0.000 & 0.000 & 0.000 & 0.000 \\
\hline 7 & 1 & 10-Feb & $11: 17$ & 0.000 & 0.000 & 0.000 & 0.000 \\
\hline 7 & 2 & 10-Feb & $11: 18$ & 0.000 & 0.000 & 0.000 & 0.000 \\
\hline 7 & 3 & $10-\mathrm{Feb}$ & $11: 19$ & 0.000 & 0.000 & 0.000 & 0.000 \\
\hline 7 & 4 & 10-Feb & $11: 20$ & 0.000 & 0.000 & 0.000 & 0.000 \\
\hline 8 & 1 & 10-Feb & $10: 59$ & 0.000 & 0.000 & 0.000 & 0.016 \\
\hline 8 & 2 & 10-Feb & 11:02 & 0.000 & 0.018 & 0.000 & 0.001 \\
\hline 8 & 3 & 10-Feb & 11:03 & 0.000 & 0.000 & 0.000 & 0.000 \\
\hline 8 & 4 & $10-\mathrm{Feb}$ & 11:04 & 0.000 & 0.000 & 0.000 & 0.001 \\
\hline 9 & 1 & 10-Feb & $10: 53$ & 0.000 & 0.000 & 0.000 & 0.000 \\
\hline 9 & 2 & 10-Feb & $10: 54$ & 0.000 & 0.000 & 0.000 & 0.000 \\
\hline 9 & 3 & $10-\mathrm{Feb}$ & $10: 55$ & 0.000 & 0.000 & 0.000 & 0.000 \\
\hline 9 & 4 & $10-\mathrm{Feb}$ & $10: 56$ & 0.000 & 0.022 & 0.000 & 0.000 \\
\hline 10 & 1 & $10-F e b$ & $10: 45$ & 0.000 & 0.004 & 0.000 & 0.001 \\
\hline 10 & 2 & 10-Feb & $10: 46$ & 0.000 & 0.007 & 0.000 & 0.009 \\
\hline 10 & 3 & 10-Feb & $10: 47$ & 0.000 & 0.006 & 0.000 & 0.000 \\
\hline 10 & 4 & $10-\mathrm{Feb}$ & $10: 48$ & 0.002 & 0.007 & 0.000 & 0.002 \\
\hline 11 & 1 & 10-Feb & $10: 37$ & 0.005 & 0.007 & 0.000 & 0.013 \\
\hline 11 & 2 & $10-\mathrm{Feb}$ & $10: 39$ & 0.213 & 0.209 & 0.000 & 0.062 \\
\hline 11 & 3 & 10-Feb & $10: 40$ & 0.718 & 1.255 & 0.000 & 0.624 \\
\hline 11 & 4 & $10-F e b$ & $10: 41$ & 0.738 & 1.610 & 0.000 & 0.870 \\
\hline 12 & 1 & 10-Feb & $10: 27$ & 0.171 & 0.325 & 0.000 & 0.000 \\
\hline 12 & 2 & 10-Feb & $10: 28$ & 0.000 & 0.005 & 0.000 & 0.007 \\
\hline 12 & 3 & 10-Feb & $10: 31$ & 0.624 & 2.577 & 0.000 & 0.327 \\
\hline 12 & 4 & $10-\mathrm{Feb}$ & $10: 32$ & 0.428 & 1.119 & 0.000 & 0.402 \\
\hline 13 & 1 & 10-Feb & $10: 16$ & 0.000 & 0.000 & 0.000 & 0.000 \\
\hline 13 & 2 & 10-Feb & $10: 18$ & 0.016 & 0.010 & 0.000 & 0.021 \\
\hline
\end{tabular}




\begin{tabular}{|c|c|c|c|c|c|c|c|}
\hline Location & Port & Date & Time & PDCB & $\mathrm{PMCH}$ & o-PDCH & PMCP \\
\hline 13 & 3 & $10-\mathrm{Feb}$ & $10: 19$ & 0.002 & 0.000 & 0.000 & 0.000 \\
\hline 13 & 4 & $10-\mathrm{Feb}$ & $10: 21$ & 0.135 & 0.421 & 0.000 & 0.027 \\
\hline 14 & 2 & 10-Feb & $9: 49$ & 0.000 & 0.011 & 0.000 & 0.004 \\
\hline 14 & 3 & $10-\mathrm{Feb}$ & $9: 54$ & 0.070 & 0.191 & 0.000 & 0.063 \\
\hline 14 & 4 & 10-Feb & 10:11 & 0.000 & 0.000 & 0.000 & 0.000 \\
\hline 15 & 2 & 10-Feb & $9: 37$ & 0.005 & 0.013 & 0.000 & 0.069 \\
\hline 15 & 3 & 10-Feb & $9: 41$ & 0.000 & 0.000 & 0.000 & 0.000 \\
\hline 15 & 4 & $10-\mathrm{Feb}$ & $9: 44$ & 0.014 & 0.103 & 0.003 & 0.011 \\
\hline 16 & $S$ & 10-Feb & $10: 20$ & 0.021 & 0.066 & 0.000 & 0.196 \\
\hline 16 & 1 & $10-F e b$ & $\wedge$ & 1.257 & 1.429 & 0.004 & 26.374 \\
\hline 16 & 2 & $10-F e b$ & $\wedge$ & 4.756 & 4.895 & 0.000 & 15.226 \\
\hline 16 & 3 & 10-Feb & $\wedge$ & 6.731 & 8.417 & 0.000 & 71.218 \\
\hline 16 & 4 & 10-Feb & $10: 26$ & 5.877 & 13.467 & 0.000 & 11.007 \\
\hline 17 & $\mathrm{~S}$ & $10-\mathrm{Feb}$ & $10: 30$ & 0.029 & 0.191 & 0.000 & 0.015 \\
\hline 17 & 1 & $10-\mathrm{Feb}$ & $\wedge$ & 0.842 & 4.733 & 0.000 & 0.087 \\
\hline 17 & 3 & $10-\mathrm{Feb}$ & $\wedge$ & 5.183 & 35.969 & 0.002 & 25.925 \\
\hline 17 & 4 & $10-F e b$ & $10: 41$ & 3.493 & 31.153 & 0.000 & 3.756 \\
\hline 18 & $\mathrm{~S}$ & $10-F e b$ & $10: 45$ & 1.846 & 10.850 & 0.000 & 1.006 \\
\hline 18 & 1 & 10-Feb & $\wedge$ & 4.846 & 25.303 & 0.000 & 3.907 \\
\hline 18 & 2 & 10-Feb & $\wedge$ & 3.843 & 26.287 & 0.000 & 8.438 \\
\hline 18 & 3 & 10-Feb & $\wedge$ & 2.712 & 24.941 & 0.000 & 13.243 \\
\hline 19 & 1 & 10-Feb & $10: 56$ & 0.448 & 1.917 & 0.143 & 32.080 \\
\hline 19 & 2 & 10-Feb & $\wedge$ & 0.494 & 3.148 & 0.101 & 26.925 \\
\hline 19 & 3 & 10-Feb & $\wedge$ & 0.277 & 4.081 & 0.083 & 23.597 \\
\hline 19 & 4 & $10-F e b$ & $11: 20$ & 1.105 & 6.918 & 0.000 & 9.464 \\
\hline 20 & $S$ & 10-Feb & $10: 36$ & 0.027 & 0.074 & 0.000 & 0.512 \\
\hline 20 & 1 & $10-\mathrm{Feb}$ & $10: 39$ & 0.570 & 2.314 & 0.647 & 74.457 \\
\hline 20 & 2 & $10-\mathrm{Feb}$ & $10: 41$ & 2.357 & 6.300 & 0.008 & 35.286 \\
\hline 20 & 3 & 10-Feb & $10: 42$ & 0.415 & 4.147 & 0.015 & 8.320 \\
\hline 21 & S & 10-Feb & 10:06 & 0.106 & 0.229 & 0.006 & 6.078 \\
\hline 21 & 1 & $10-\mathrm{Feb}$ & $10: 12$ & 0.402 & 0.744 & 0.009 & 4.891 \\
\hline 21 & 3 & 10-Feb & 10:19 & 8.972 & 8.033 & 0.012 & 64.329 \\
\hline 21 & 4 & 10-Feb & $10: 23$ & 4.957 & 3.907 & 0.003 & 15.722 \\
\hline 22 & S & 10-Feb & $9: 50$ & 0.048 & 0.125 & 0.010 & 2.721 \\
\hline 22 & 1 & 10-Feb & $9: 52$ & 0.694 & 2.576 & 0.661 & 81.972 \\
\hline 22 & 2 & $10-F e b$ & $9: 54$ & 0.000 & 0.000 & 0.000 & 0.006 \\
\hline 22 & 3 & $10-\mathrm{Feb}$ & $9: 56$ & 3.509 & 4.661 & 0.031 & 86.181 \\
\hline 22 & 4 & 10-Feb & $9: 59$ & 10.658 & 7.321 & 0.000 & 56.010 \\
\hline 23 & 1 & $10-\mathrm{Feb}$ & $9: 40$ & 0.028 & 0.037 & 0.000 & 0.038 \\
\hline 23 & 3 & $10-F e b$ & $9: 44$ & 3.124 & 4.640 & 0.000 & 81.825 \\
\hline 23 & 4 & 10-Feb & $9: 46$ & 4.974 & 5.611 & 0.000 & 73.080 \\
\hline 24 & 1 & $10-\mathrm{Feb}$ & $9: 18$ & 0.000 & 0.119 & 0.000 & 0.685 \\
\hline 24 & 2 & 10-Feb & $9: 21$ & 1.689 & 2.880 & 0.025 & 76.364 \\
\hline 24 & 3 & 10-Feb & $9: 24$ & 9.895 & 7.778 & 0.000 & 28.723 \\
\hline 24 & 4 & 10-Feb & $9: 30$ & 25.872 & 13.229 & 0.000 & 3.475 \\
\hline 25 & 1 & $10-\mathrm{Feb}$ & 9:00 & 0.000 & 0.049 & 0.005 & 2.894 \\
\hline 25 & 2 & 10-Feb & 9:05 & 0.913 & 1.680 & 0.000 & 41.032 \\
\hline
\end{tabular}




\begin{tabular}{|c|c|c|c|c|c|c|c|}
\hline Location & Port & Date & Time & PDCB & $\mathrm{PMCH}$ & o-PDCH & PMCP \\
\hline 25 & 3 & $10-\mathrm{Feb}$ & 9:09 & 0.163 & 1.182 & 0.042 & 18.307 \\
\hline 25 & 4 & $10-\mathrm{Feb}$ & $9: 14$ & 0.692 & 3.542 & 0.025 & 39.490 \\
\hline 26 & 1 & 10-Feb & $11: 33$ & 0.003 & 0.046 & 0.000 & 0.032 \\
\hline 27 & 1 & 10-Feb & $11: 37$ & 0.022 & 0.293 & 0.000 & 0.102 \\
\hline 28 & 1 & $10-\mathrm{Feb}$ & $11: 40$ & 0.124 & 1.395 & 0.000 & 0.049 \\
\hline 29 & 1 & 10-Feb & $11: 42$ & 0.000 & 0.022 & 0.000 & 0.025 \\
\hline 31 & 1 & 10-Feb & $11: 46$ & 0.000 & 0.172 & 0.000 & 0.012 \\
\hline 32 & 1 & 10-Feb & $11: 50$ & 0.000 & 0.000 & 0.000 & 0.007 \\
\hline 33 & 1 & 10-Feb & $10: 56$ & 0.001 & 0.000 & 0.000 & 0.012 \\
\hline 35 & 1 & 10-Feb & $11: 28$ & 0.000 & 0.000 & 0.000 & 0.000 \\
\hline 36 & 1 & 10-Feb & $11: 30$ & 0.000 & 0.004 & 0.000 & 0.005 \\
\hline 37 & 1 & 10-Feb & $11: 32$ & 0.220 & 2.421 & 0.000 & 0.000 \\
\hline 38 & 1 & 10-Feb & $11: 34$ & 0.000 & 0.016 & 0.000 & 0.002 \\
\hline 39 & 1 & 10-Feb & $11: 40$ & 0.000 & 0.012 & 0.000 & 0.009 \\
\hline 40 & 1 & 10-Feb & $10: 53$ & 0.008 & 0.045 & 0.000 & 0.093 \\
\hline 41 & 1 & 10-Feb & 11:05 & 0.061 & 0.239 & 0.005 & 0.626 \\
\hline 42 & 1 & 10-Feb & 9:02 & 0.000 & 0.000 & 0.000 & 0.008 \\
\hline 42 & 2 & $10-\mathrm{Feb}$ & 9:07 & 0.000 & 0.000 & 0.000 & 0.000 \\
\hline 42 & 3 & 10-Feb & $9: 11$ & 0.069 & 0.387 & 0.000 & 0.709 \\
\hline NDBTC & & 10-Feb & $11: 42$ & 0.000 & 1.679 & 1.154 & 82.669 \\
\hline NDPTC & & 10-Feb & $11: 53$ & 0.067 & 0.100 & 0.010 & 6.263 \\
\hline NLIP & & 10-Feb & $12: 18$ & 0.000 & 1.708 & 10.825 & 82.074 \\
\hline SDBTC & & 10-Feb & $11: 44$ & 0.155 & 3.505 & 0.000 & 17.027 \\
\hline SDPTC & & 10-Feb & $11: 54$ & 0.004 & 0.033 & 0.000 & 0.191 \\
\hline SLIP & & 10-Feb & $12: 12$ & 0.000 & 5.890 & 0.054 & 852.077 \\
\hline 1 & S & 12-Feb & $11: 55$ & 0.083 & 2.813 & 0.000 & 4.325 \\
\hline 1 & 1 & 12-Feb & $\wedge$ & 0.076 & 2.811 & 0.000 & 7.394 \\
\hline 1 & 2 & 12-Feb & $\wedge$ & 0.000 & 1.531 & 0.014 & 15.482 \\
\hline 1 & 3 & 12-Feb & $\wedge$ & 0.000 & 2.033 & 0.008 & 12.054 \\
\hline 1 & 4 & 12-Feb & $12: 15$ & 0.211 & 5.563 & 0.005 & 3.780 \\
\hline 2 & $S$ & 12-Feb & $13: 34$ & 0.000 & 0.015 & 0.000 & 0.004 \\
\hline 2 & 1 & 12-Feb & $\wedge$ & 0.057 & 1.000 & 0.000 & 0.025 \\
\hline 2 & 2 & 12-Feb & $\wedge$ & 0.196 & 4.411 & 0.000 & 0.610 \\
\hline 2 & 3 & 12-Feb & $\wedge$ & 0.266 & 6.076 & 0.000 & 4.482 \\
\hline 2 & 4 & 12-Feb & $13: 44$ & 0.151 & 2.249 & 0.011 & 2.456 \\
\hline 3 & S & $12-F e b$ & $13: 42$ & 0.129 & 1.444 & 0.000 & 0.092 \\
\hline 3 & 1 & 12-Feb & $\wedge$ & 0.328 & 3.353 & 0.000 & 0.123 \\
\hline 3 & 2 & 12-Feb & $\wedge$ & 0.545 & 5.356 & 0.000 & 0.286 \\
\hline 3 & 3 & 12-Feb & $\wedge$ & 0.613 & 6.535 & 0.003 & 1.428 \\
\hline 3 & 4 & 12-Feb & $13: 55$ & 0.271 & 3.446 & 0.027 & 4.551 \\
\hline 4 & $\mathrm{~S}$ & $12-\mathrm{Feb}$ & $13: 58$ & 0.005 & 0.345 & 0.000 & 0.106 \\
\hline 4 & 1 & 12-Feb & $13: 59$ & 0.003 & 0.039 & 0.004 & 0.075 \\
\hline 4 & 2 & 12-Feb & $\wedge$ & 0.124 & 1.858 & 0.022 & 3.474 \\
\hline 4 & 3 & 12-Feb & $\wedge$ & 0.287 & 3.397 & 0.038 & 7.132 \\
\hline 4 & 4 & 12-Feb & 14:08 & 0.170 & 2.435 & 0.028 & 4.531 \\
\hline 5 & $S$ & 12-Feb & $14: 12$ & 0.000 & 0.065 & 0.004 & 0.039 \\
\hline 5 & 1 & 12-Feb & $\wedge$ & 0.043 & 0.663 & 0.000 & 0.166 \\
\hline
\end{tabular}




\begin{tabular}{|c|c|c|c|c|c|c|c|}
\hline Location & Port & Date & Time & PDCB & $\mathrm{PMCH}$ & o-PDCH & PMCP \\
\hline 5 & 2 & 12-Feb & $\wedge$ & 0.085 & 1.115 & 0.000 & 0.346 \\
\hline 5 & 3 & 12-Feb & $\wedge$ & 0.136 & 1.655 & 0.007 & 1.831 \\
\hline 5 & 4 & 12-Feb & $14: 26$ & 0.138 & 1.763 & 0.010 & 2.961 \\
\hline 6 & $S$ & 12-Feb & $14: 04$ & 0.000 & 0.000 & 0.000 & 0.000 \\
\hline 6 & 1 & $12-F e b$ & 14:06 & 0.000 & 0.010 & 0.000 & 0.000 \\
\hline 6 & 2 & 12-Feb & $14: 08$ & 0.000 & 0.012 & 0.000 & 0.008 \\
\hline 6 & 3 & 12-Feb & $14: 10$ & 0.000 & 0.010 & 0.000 & 0.019 \\
\hline 6 & 4 & 12-Feb & $14: 12$ & 0.000 & 0.000 & 0.000 & 0.000 \\
\hline 7 & S & 12-Feb & $13: 49$ & 0.000 & 0.000 & 0.000 & 0.001 \\
\hline 7 & 1 & 12-Feb & $13: 50$ & 0.000 & 0.000 & 0.000 & 0.000 \\
\hline 7 & 2 & 12-Feb & $13: 52$ & 0.000 & 0.000 & 0.000 & 0.000 \\
\hline 7 & 3 & 12-Feb & $13: 55$ & 0.000 & 0.000 & 0.000 & 0.000 \\
\hline 7 & 4 & 12-Feb & $13: 59$ & 0.000 & 0.000 & 0.000 & 0.000 \\
\hline 8 & 1 & 12-Feb & $13: 37$ & 0.000 & 0.000 & 0.000 & 0.000 \\
\hline 8 & 2 & 12-Feb & $13: 38$ & 0.000 & 0.000 & 0.000 & 0.000 \\
\hline 8 & 3 & 12-Feb & $13: 40$ & 0.000 & 0.000 & 0.000 & 0.000 \\
\hline 8 & 4 & 12-Feb & $13: 43$ & 0.000 & 0.000 & 0.000 & 0.001 \\
\hline 9 & 1 & 12-Feb & $11: 51$ & 0.000 & 0.000 & 0.000 & 0.000 \\
\hline 9 & 2 & 12-Feb & $11: 52$ & 0.000 & 0.000 & 0.000 & 0.000 \\
\hline 9 & 3 & 12-Feb & $11: 53$ & 0.000 & 0.003 & 0.000 & 0.000 \\
\hline 9 & 4 & 12-Feb & $11: 54$ & 0.000 & 0.005 & 0.000 & 0.000 \\
\hline 10 & 1 & 12-Feb & $11: 45$ & 0.000 & 0.000 & 0.000 & 0.002 \\
\hline 10 & 2 & 12-Feb & $11: 46$ & 0.000 & 0.000 & 0.000 & 0.003 \\
\hline 10 & 3 & 12-Feb & $11: 47$ & 0.000 & 0.000 & 0.000 & 0.001 \\
\hline 10 & 4 & 12-Feb & $11: 48$ & 0.000 & 0.005 & 0.000 & 0.002 \\
\hline 11 & 1 & 12-Feb & $11: 39$ & 0.000 & 0.000 & 0.000 & 0.000 \\
\hline 11 & 2 & 12-Feb & $11: 40$ & 0.083 & 0.088 & 0.000 & 0.078 \\
\hline 11 & 3 & 12-Feb & $11: 41$ & 0.331 & 0.634 & 0.008 & 1.181 \\
\hline 11 & 4 & 12-Feb & $11: 42$ & 0.182 & 0.483 & 0.014 & 1.338 \\
\hline 12 & 1 & 12-Feb & $11: 32$ & 0.105 & 0.175 & 0.000 & 0.041 \\
\hline 12 & 2 & 12-Feb & $11: 33$ & 0.000 & 0.000 & 0.000 & 0.000 \\
\hline 12 & 3 & 12-Feb & $11: 35$ & 0.372 & 1.334 & 0.000 & 0.859 \\
\hline 12 & 4 & 12-Feb & $11: 36$ & 0.152 & 0.521 & 0.002 & 0.535 \\
\hline 13 & 1 & $12-\mathrm{Feb}$ & $11: 25$ & 0.000 & 0.000 & 0.000 & 0.000 \\
\hline 13 & 2 & 12-Feb & $11: 26$ & 0.002 & 0.000 & 0.000 & 0.003 \\
\hline 13 & 3 & 12-Feb & $11: 27$ & 0.003 & 0.000 & 0.000 & 0.000 \\
\hline 13 & 4 & 12-Feb & $11: 28$ & 0.041 & 0.119 & 0.000 & 0.036 \\
\hline 14 & 2 & 12-Feb & $11: 19$ & 0.000 & 0.000 & 0.000 & 0.000 \\
\hline 14 & 3 & 12-Feb & $11: 20$ & 0.003 & 0.000 & 0.000 & 0.003 \\
\hline 14 & 4 & 12-Feb & $11: 21$ & 0.000 & 0.000 & 0.000 & 0.000 \\
\hline 15 & 2 & 12-Feb & $11: 14$ & 0.000 & 0.000 & 0.000 & 0.000 \\
\hline 15 & 3 & 12-Feb & $11: 15$ & 0.000 & 0.000 & 0.000 & 0.000 \\
\hline 15 & 4 & 12-Feb & $11: 16$ & 0.000 & 0.000 & 0.000 & 0.000 \\
\hline 16 & S & 12-Feb & $14: 32$ & 0.014 & 0.226 & 0.003 & 0.071 \\
\hline 16 & 1 & $12-\mathrm{Feb}$ & $14: 34$ & 0.298 & 1.587 & 0.210 & 7.797 \\
\hline 16 & 2 & 12-Feb & $14: 36$ & 1.881 & 7.353 & 0.115 & 16.982 \\
\hline 16 & 3 & 12-Feb & $14: 40$ & 1.481 & 5.839 & 1.095 & 43.498 \\
\hline
\end{tabular}




\begin{tabular}{|c|c|c|c|c|c|c|c|}
\hline Location & Port & Date & Time & PDCB & $\mathrm{PMCH}$ & o-PDCH & PMCP \\
\hline 16 & 4 & 12-Feb & $14: 42$ & 1.856 & 12.571 & 0.531 & 29.294 \\
\hline 17 & $\mathrm{~S}$ & 12-Feb & $14: 15$ & 0.038 & 0.282 & 0.000 & 0.078 \\
\hline 17 & 1 & 12-Feb & $14: 18$ & 0.872 & 4.914 & 0.003 & 0.726 \\
\hline 17 & 2 & 12-Feb & $14: 22$ & 0.147 & 1.263 & 0.014 & 0.605 \\
\hline 17 & 3 & 12-Feb & $14: 23$ & 2.997 & 24.821 & 0.285 & 13.817 \\
\hline 17 & 4 & 12-Feb & $14: 28$ & 3.172 & 29.370 & 0.102 & 5.906 \\
\hline 18 & $\mathrm{~S}$ & 12-Feb & $14: 05$ & 0.577 & 4.935 & 0.043 & 8.556 \\
\hline 18 & 1 & 12-Feb & 14:07 & 0.694 & 4.923 & 0.084 & 19.211 \\
\hline 18 & 2 & 12-Feb & 14:08 & 0.564 & 4.413 & 0.108 & 21.613 \\
\hline 18 & 3 & 12-Feb & $14: 10$ & 0.330 & 3.722 & 0.142 & 20.679 \\
\hline 18 & 4 & 12-Feb & 14:11 & 0.975 & 9.659 & 0.098 & 18.386 \\
\hline 19 & S & 12-Feb & $13: 54$ & 0.000 & 0.046 & 0.010 & 0.145 \\
\hline 19 & 1 & 12-Feb & $13: 57$ & 0.000 & 0.287 & 0.144 & 4.664 \\
\hline 19 & 2 & 12-Feb & $13: 58$ & 0.000 & 0.452 & 0.157 & 7.037 \\
\hline 19 & 3 & 12-Feb & $14: 00$ & 0.000 & 0.767 & 0.192 & 10.433 \\
\hline 19 & 4 & 12-Feb & 14:01 & 0.130 & 1.547 & 0.188 & 16.073 \\
\hline 20 & S & 12-Feb & $13: 39$ & 0.000 & 0.010 & 0.009 & 0.098 \\
\hline 20 & 1 & 12-Feb & $13: 41$ & 0.000 & 0.176 & 0.248 & 4.071 \\
\hline 20 & 2 & 12-Feb & $13: 42$ & 0.000 & 0.067 & 0.022 & 1.158 \\
\hline 20 & 3 & 12-Feb & $13: 44$ & 0.130 & 1.402 & 0.219 & 15.813 \\
\hline 20 & 4 & 12-Feb & $13: 48$ & 0.073 & 0.702 & 0.109 & 5.358 \\
\hline 21 & $\mathrm{~S}$ & 12-Feb & $11: 50$ & 0.000 & 0.015 & 0.010 & 0.279 \\
\hline 21 & 1 & 12-Feb & $11: 54$ & 0.000 & 0.311 & 0.823 & 7.404 \\
\hline 21 & 2 & 12-Feb & $11: 58$ & 0.045 & 0.120 & 0.065 & 1.234 \\
\hline 21 & 3 & $12-\mathrm{F}$ & 12:01 & 0.805 & 1.945 & 0.762 & 48.093 \\
\hline 21 & 4 & 12-Feb & $12: 05$ & 0.291 & 0.779 & 0.308 & 16.956 \\
\hline 22 & $S$ & 12-Feb & $11: 36$ & 0.000 & 0.016 & 0.010 & 0.193 \\
\hline 22 & 1 & 12-Feb & $11: 38$ & 0.037 & 0.140 & 0.080 & 1.480 \\
\hline 22 & 2 & 12-Feb & $11: 40$ & 0.112 & 0.716 & 0.746 & 19.524 \\
\hline 22 & 3 & 12-Feb & $11: 44$ & 0.260 & 1.091 & 0.899 & 27.991 \\
\hline 22 & 4 & 12-Feb & $11: 46$ & 1.380 & 2.265 & 0.741 & 45.940 \\
\hline 23 & 1 & 12-Feb & $11: 27$ & 0.009 & 0.024 & 0.000 & 0.117 \\
\hline 23 & 2 & 12-Feb & $11: 29$ & 0.209 & 0.680 & 0.587 & 17.112 \\
\hline 23 & 3 & 12-Feb & $11: 30$ & 0.345 & 1.294 & 0.714 & 37.307 \\
\hline 23 & 4 & 12-Feb & $11: 31$ & 0.503 & 1.753 & 0.734 & 47.932 \\
\hline 24 & 1 & 12-Feb & $11: 20$ & 0.000 & 0.000 & 0.000 & 0.000 \\
\hline 24 & 2 & 12-Feb & $11: 22$ & 0.153 & 0.569 & 0.436 & 15.724 \\
\hline 24 & 3 & 12-Feb & $11: 23$ & 1.139 & 2.214 & 0.374 & 50.999 \\
\hline 24 & 4 & 12-Feb & $11: 24$ & 6.656 & 5.759 & 0.062 & 50.397 \\
\hline 25 & 1 & 12-Feb & 11:07 & 0.000 & 0.000 & 0.000 & 0.005 \\
\hline 25 & 2 & 12-Feb & 11:09 & 0.014 & 0.020 & 0.000 & 0.573 \\
\hline 26 & 1 & 12-Feb & $14: 17$ & 0.000 & 0.000 & 0.000 & 0.000 \\
\hline 27 & 1 & 12-Feb & $14: 19$ & 0.000 & 0.000 & 0.000 & 0.000 \\
\hline 28 & 1 & 12-Feb & $14: 24$ & 0.019 & 0.282 & 0.000 & 0.159 \\
\hline 29 & 1 & $12-\mathrm{Feb}$ & $14: 28$ & 0.000 & 0.000 & 0.000 & 0.000 \\
\hline 31 & 1 & 12-Feb & $14: 53$ & 0.000 & 0.005 & 0.000 & 0.002 \\
\hline 32 & 1 & 12-Feb & $15: 09$ & 0.000 & 0.022 & 0.000 & 0.014 \\
\hline
\end{tabular}




\begin{tabular}{|c|c|c|c|c|c|c|c|}
\hline Location & Port & Date & Time & PDCB & $\mathrm{PMCH}$ & o-PDCH & PMCP \\
\hline 33 & 1 & 12-Feb & $14: 56$ & 0.000 & 0.015 & 0.000 & 0.014 \\
\hline 34 & 1 & 12-Feb & $14: 53$ & 0.002 & 0.038 & 0.004 & 0.035 \\
\hline 35 & 1 & 12-Feb & $14: 34$ & 0.000 & 0.000 & 0.000 & 0.001 \\
\hline 36 & 1 & 12-Feb & $14: 36$ & 0.000 & 0.000 & 0.000 & 0.001 \\
\hline 37 & 1 & $12-\mathrm{Feb}$ & $14: 40$ & 0.122 & 1.421 & 0.000 & 0.189 \\
\hline 38 & 1 & 12-Feb & $14: 43$ & 0.001 & 0.030 & 0.000 & 0.003 \\
\hline 39 & 1 & 12-Feb & $14: 49$ & 0.000 & 0.007 & 0.000 & 0.000 \\
\hline 40 & 1 & 12-Feb & $14: 59$ & 0.002 & 0.037 & 0.003 & 0.030 \\
\hline 41 & 1 & $12-\mathrm{Feb}$ & $14: 49$ & 0.006 & 0.138 & 0.013 & 0.123 \\
\hline 42 & 1 & 12-Feb & 11:05 & 0.000 & 0.000 & 0.000 & 0.000 \\
\hline 42 & 2 & 12-Feb & 11:06 & 0.000 & 0.000 & 0.000 & 0.000 \\
\hline 42 & 3 & 12-Feb & 11:07 & 0.000 & 0.008 & 0.000 & 0.004 \\
\hline 42 & 4 & 12-Feb & 11:08 & 0.000 & 0.014 & 0.000 & 0.050 \\
\hline NDBTC & & 12-Feb & 15:07 & 0.000 & 0.261 & 1.769 & 7.890 \\
\hline NDPTC & & 12-Feb & $14: 45$ & 0.000 & 0.077 & 3.052 & 11.512 \\
\hline NLIP & & 12-Feb & $14: 33$ & 0.000 & 0.622 & 42.059 & 24.914 \\
\hline PSTC & & 12-Feb & $14: 58$ & 0.053 & 0.035 & 0.212 & 2.047 \\
\hline SDBTC & & 12-Feb & $15: 00$ & 0.000 & 0.061 & 0.051 & 2.111 \\
\hline SDPTC & & 12-Feb & $14: 48$ & 0.000 & 0.040 & 1.126 & 5.822 \\
\hline SLIP & & 12-Feb & $14: 30$ & 0.000 & 3.405 & 0.084 & 1282.603 \\
\hline 1 & $\mathrm{~S}$ & 14-Feb & $9: 50$ & 0.025 & 1.083 & 0.000 & 1.494 \\
\hline 1 & 1 & 14-Feb & $\wedge$ & 0.035 & 1.251 & 0.005 & 3.453 \\
\hline 1 & 2 & 14-Feb & $\wedge$ & 0.000 & 1.086 & 0.040 & 15.006 \\
\hline 1 & 3 & 14-Feb & $\wedge$ & 0.000 & 1.841 & 0.022 & 9.211 \\
\hline 1 & 4 & 14-Feb & $9: 55$ & 0.111 & 3.347 & 0.007 & 2.515 \\
\hline 2 & $\mathrm{~S}$ & $14-F e b$ & $9: 57$ & 0.006 & 0.060 & 0.000 & 0.007 \\
\hline 2 & 1 & 14-Feb & $\wedge$ & 0.072 & 1.111 & 0.000 & 0.066 \\
\hline 2 & 2 & 14-Feb & $\wedge$ & 0.187 & 3.496 & 0.000 & 0.826 \\
\hline 2 & 3 & 14-Feb & $\wedge$ & 0.227 & 4.786 & 0.007 & 3.848 \\
\hline 2 & 4 & 14-Feb & 10:03 & 0.343 & 4.264 & 0.022 & 3.942 \\
\hline 3 & $S$ & 14-Feb & 10:05 & 0.082 & 1.017 & 0.000 & 0.233 \\
\hline 3 & 1 & 14-Feb & $\wedge$ & 0.217 & 2.534 & 0.000 & 0.527 \\
\hline 3 & 2 & $14-F e b$ & $\wedge$ & 0.394 & 4.185 & 0.004 & 0.908 \\
\hline 3 & 3 & 14-Feb & $\wedge$ & 0.151 & 1.850 & 0.003 & 0.582 \\
\hline 3 & 4 & 14-Feb & $10: 10$ & 0.263 & 6.340 & 4.773 & 2.875 \\
\hline 4 & $\mathrm{~S}$ & 14-Feb & 10:11 & 0.008 & 0.283 & 0.002 & 0.087 \\
\hline 4 & 1 & 14-Feb & $10: 14$ & 0.000 & 0.008 & 0.000 & 0.015 \\
\hline 4 & 2 & 14-Feb & $\wedge$ & 0.045 & 0.562 & 0.003 & 0.558 \\
\hline 4 & 3 & 14-Feb & $\wedge$ & 0.161 & 2.055 & 0.014 & 2.320 \\
\hline 4 & 4 & 14-Feb & $10: 19$ & 0.187 & 2.343 & 0.020 & 3.015 \\
\hline 5 & $\mathrm{~S}$ & $14-F e b$ & $10: 20$ & 0.003 & 0.030 & 0.000 & 0.024 \\
\hline 5 & S & 14-Feb & 11:06 & 0.000 & 0.013 & 0.000 & 0.005 \\
\hline 5 & 1 & 14-Feb & $\wedge$ & 0.015 & 0.206 & 0.000 & 0.066 \\
\hline 5 & 1 & 14-Feb & 11:08 & 0.016 & 0.214 & 0.000 & 0.065 \\
\hline 5 & 2 & 14-Feb & $\wedge$ & 0.037 & 0.563 & 0.000 & 0.854 \\
\hline 5 & 2 & 14-Feb & 11:09 & 0.041 & 0.569 & 0.000 & 0.201 \\
\hline 5 & 3 & 14-Feb & $11: 11$ & 0.074 & 0.979 & 0.000 & 0.714 \\
\hline
\end{tabular}




\begin{tabular}{|c|c|c|c|c|c|c|c|}
\hline Location & Port & Date & Time & PDCB & $\mathrm{PMCH}$ & o-PDCH & PMCP \\
\hline 5 & 4 & 14-Feb & $10: 25$ & 0.080 & 1.025 & 0.005 & 1.235 \\
\hline 5 & 4 & 14-Feb & $11: 14$ & 0.078 & 1.032 & 0.005 & 1.254 \\
\hline 6 & $S$ & 14-Feb & $11: 16$ & 0.000 & 0.015 & 0.000 & 0.004 \\
\hline 6 & 1 & 14-Feb & $11: 18$ & 0.003 & 0.044 & 0.000 & 0.007 \\
\hline 6 & 2 & $14-F e b$ & $11: 20$ & 0.003 & 0.053 & 0.000 & 0.033 \\
\hline 6 & 3 & 14-Feb & $11: 21$ & 0.003 & 0.045 & 0.000 & 0.071 \\
\hline 6 & 4 & 14-Feb & $11: 23$ & 0.002 & 0.034 & 0.000 & 0.045 \\
\hline 7 & S & 14-Feb & $11: 13$ & 0.000 & 0.008 & 0.004 & 0.001 \\
\hline 7 & 1 & 14-Feb & $11: 14$ & 0.000 & 0.000 & 0.000 & 0.000 \\
\hline 7 & 2 & 14-Feb & $11: 16$ & 0.000 & 0.000 & 0.000 & 0.002 \\
\hline 7 & 3 & 14-Feb & $11: 17$ & 0.001 & 0.006 & 0.000 & 0.004 \\
\hline 7 & 4 & 14-Feb & $11: 20$ & 0.000 & 0.012 & 0.000 & 0.006 \\
\hline 8 & 1 & 14-Feb & $10: 56$ & 0.003 & 0.016 & 0.000 & 0.012 \\
\hline 8 & 2 & 14-Feb & $10: 59$ & 0.002 & 0.009 & 0.000 & 0.008 \\
\hline 8 & 3 & 14-Feb & $11: 03$ & 0.000 & 0.000 & 0.000 & 0.006 \\
\hline 8 & 4 & 14-Feb & 11:07 & 0.001 & 0.007 & 0.000 & 0.006 \\
\hline 9 & 1 & 14-Feb & $10: 48$ & 0.000 & 0.000 & 0.000 & 0.006 \\
\hline 9 & 2 & 14-Feb & $10: 49$ & 0.000 & 0.000 & 0.000 & 0.003 \\
\hline 9 & 3 & 14-Feb & $10: 50$ & 0.001 & 0.028 & 0.004 & 0.004 \\
\hline 9 & 4 & $14-\mathrm{Feb}$ & $10: 53$ & 0.000 & 0.006 & 0.000 & 0.003 \\
\hline 10 & 1 & 14-Feb & $10: 42$ & 0.000 & 0.000 & 0.000 & 0.000 \\
\hline 10 & 2 & 14-Feb & $10: 43$ & 0.000 & 0.000 & 0.000 & 0.000 \\
\hline 10 & 3 & 14-Feb & $10: 44$ & 0.000 & 0.000 & 0.000 & 0.003 \\
\hline 10 & 4 & 14-Feb & $10: 45$ & 0.000 & 0.014 & 0.000 & 0.079 \\
\hline 11 & 1 & 14-Feb & $10: 35$ & 0.000 & 0.000 & 0.000 & 0.002 \\
\hline 11 & 2 & 14-Feb & $10: 36$ & 0.087 & 0.120 & 0.000 & 0.130 \\
\hline 11 & 3 & 14-Feb & $10: 37$ & 0.267 & 0.544 & 0.012 & 0.817 \\
\hline 11 & 4 & 14-Feb & $10: 38$ & 0.168 & 0.487 & 0.017 & 0.853 \\
\hline 12 & 1 & 14-Feb & $10: 27$ & 0.119 & 0.233 & 0.000 & 0.078 \\
\hline 12 & 2 & 14-Feb & $10: 28$ & 0.000 & 0.000 & 0.000 & 0.000 \\
\hline 12 & 3 & 14-Feb & $10: 29$ & 0.391 & 1.228 & 0.000 & 1.185 \\
\hline 12 & 4 & $14-F e b$ & $10: 30$ & 0.382 & 1.103 & 0.012 & 1.150 \\
\hline 13 & 1 & 14-Feb & $10: 20$ & 0.000 & 0.000 & 0.000 & 0.000 \\
\hline 13 & 2 & 14-Feb & $10: 21$ & 0.011 & 0.009 & 0.000 & 0.018 \\
\hline 13 & 3 & 14-Feb & $10: 22$ & 0.029 & 0.037 & 0.000 & 0.041 \\
\hline 13 & 4 & 14-Feb & $10: 23$ & 0.066 & 0.164 & 0.000 & 0.104 \\
\hline 14 & 2 & 14-Feb & $10: 11$ & 0.000 & 0.000 & 0.000 & 0.002 \\
\hline 14 & 3 & 14-Feb & $10: 12$ & 0.010 & 0.008 & 0.000 & 0.012 \\
\hline 14 & 4 & 14-Feb & $10: 13$ & 0.021 & 0.019 & 0.000 & 0.026 \\
\hline 15 & 2 & 14-Feb & $10: 02$ & 0.000 & 0.000 & 0.000 & 0.000 \\
\hline 15 & 3 & 14-Feb & 10:03 & 0.000 & 0.000 & 0.000 & 0.012 \\
\hline 15 & 4 & 14-Feb & $10: 04$ & 0.000 & 0.000 & 0.000 & 0.002 \\
\hline 16 & S & 14-Feb & $10: 27$ & 0.013 & 0.063 & 0.000 & 0.033 \\
\hline 16 & 1 & 14-Feb & $\wedge$ & 0.384 & 2.328 & 0.293 & 2.335 \\
\hline 16 & 2 & 14-Feb & $\wedge$ & 1.527 & 8.934 & 0.297 & 10.583 \\
\hline 16 & 3 & 14-Feb & $\wedge$ & 1.020 & 6.177 & 1.617 & 18.912 \\
\hline 16 & 4 & 14-Feb & $10: 34$ & 1.562 & 14.373 & 0.392 & 10.934 \\
\hline
\end{tabular}




\begin{tabular}{|c|c|c|c|c|c|c|c|}
\hline Location & Port & Date & Time & PDCB & $\mathrm{PMCH}$ & o-PDCH & PMCP \\
\hline 17 & $\mathrm{~S}$ & 14-Feb & $10: 42$ & 0.031 & 0.223 & 0.000 & 0.088 \\
\hline 17 & 1 & 14-Feb & $\wedge$ & 0.514 & 3.025 & 0.003 & 1.727 \\
\hline 17 & 2 & 14-Feb & $\wedge$ & 0.017 & 0.365 & 0.020 & 0.135 \\
\hline 17 & 3 & 14-Feb & $\wedge$ & 2.049 & 16.246 & 0.466 & 11.869 \\
\hline 17 & 4 & 14-Feb & $10: 52$ & 2.719 & 27.274 & 0.091 & 4.775 \\
\hline 18 & $\mathrm{~S}$ & $14-F e b$ & $10: 55$ & 0.375 & 3.623 & 0.046 & 5.428 \\
\hline 18 & 1 & 14-Feb & $\wedge$ & 0.370 & 2.965 & 0.138 & 14.374 \\
\hline 18 & 2 & 14-Feb & $\wedge$ & 0.273 & 2.390 & 0.175 & 16.661 \\
\hline 18 & 3 & $14-\mathrm{Feb}$ & $\wedge$ & 0.198 & 2.042 & 0.222 & 15.247 \\
\hline 18 & 4 & 14-Feb & $11: 00$ & 0.718 & 7.056 & 0.155 & 15.712 \\
\hline 19 & S & 14-Feb & 11:03 & 0.000 & 0.031 & 0.003 & 0.061 \\
\hline 19 & 1 & 14-Feb & $\wedge$ & 0.000 & 0.163 & 0.220 & 3.365 \\
\hline 19 & 2 & 14-Feb & $\wedge$ & 0.000 & 0.257 & 0.239 & 5.355 \\
\hline 19 & 3 & 14-Feb & $\wedge$ & 0.000 & 0.504 & 0.288 & 11.715 \\
\hline 19 & 4 & 14-Feb & 11:08 & 0.229 & 1.285 & 0.265 & 12.934 \\
\hline 20 & S & 14-Feb & 10:54 & 0.000 & 0.000 & 0.000 & 0.020 \\
\hline 20 & 1 & 14-Feb & 10:56 & 0.000 & 0.071 & 0.335 & 1.732 \\
\hline 20 & 2 & 14-Feb & $10: 57$ & 0.000 & 0.527 & 0.416 & 9.537 \\
\hline 20 & 4 & 14-Feb & $11: 00$ & 0.279 & 1.157 & 0.447 & 13.462 \\
\hline 21 & $\mathrm{~S}$ & 14-Feb & $10: 16$ & 0.000 & 0.007 & 0.011 & 0.095 \\
\hline 21 & 3 & 14-Feb & $10: 26$ & 0.231 & 0.814 & 1.016 & 19.303 \\
\hline 22 & $S$ & 14-Feb & 10:03 & 0.000 & 0.007 & 0.011 & 0.081 \\
\hline 22 & 1 & 14-Feb & 10:05 & 0.000 & 0.188 & 0.923 & 4.342 \\
\hline 22 & 2 & 14-Feb & 10:07 & 0.060 & 0.345 & 0.814 & 7.317 \\
\hline 22 & 3 & 14-Feb & $10: 10$ & 0.110 & 0.622 & 1.219 & 13.338 \\
\hline 22 & 4 & 14-Feb & $10: 13$ & 0.910 & 1.480 & 0.945 & 26.718 \\
\hline 23 & 1 & 14-Feb & 9:56 & 0.003 & 0.009 & 0.003 & 0.085 \\
\hline 23 & 2 & 14-Feb & $9: 57$ & 0.085 & 0.318 & 0.715 & 6.315 \\
\hline 23 & 3 & 14-Feb & 9:59 & 0.111 & 0.540 & 0.790 & 12.535 \\
\hline 23 & 4 & 14-Feb & 10:00 & 0.173 & 0.810 & 0.966 & 18.761 \\
\hline 24 & 1 & 14-Feb & $9: 48$ & 0.000 & 0.005 & 0.007 & 0.034 \\
\hline 24 & 2 & 14-Feb & $9: 50$ & 0.050 & 0.249 & 0.612 & 5.193 \\
\hline 24 & 3 & 14-Feb & $9: 52$ & 0.285 & 0.861 & 0.486 & 21.355 \\
\hline 24 & 4 & 14-Feb & $9: 53$ & 1.065 & 1.436 & 0.134 & 22.054 \\
\hline 25 & 1 & 14-Feb & $9: 37$ & 0.000 & 0.000 & 0.000 & 0.000 \\
\hline 25 & 2 & 14-Feb & $9: 39$ & 0.006 & 0.009 & 0.003 & 0.160 \\
\hline 25 & 3 & 14-Feb & $9: 42$ & 0.000 & 0.222 & 0.572 & 5.587 \\
\hline 25 & 4 & 14-Feb & $9: 46$ & 0.000 & 0.872 & 0.468 & 13.548 \\
\hline 26 & 1 & 14-Feb & $11: 21$ & 0.000 & 0.000 & 0.000 & 0.002 \\
\hline 27 & 1 & 14-Feb & $11: 23$ & 0.013 & 0.147 & 0.000 & 0.022 \\
\hline 28 & 1 & 14-Feb & $11: 27$ & 0.055 & 0.717 & 0.000 & 0.336 \\
\hline 29 & 1 & 14-Feb & $11: 30$ & 0.000 & 0.006 & 0.000 & 0.012 \\
\hline 31 & 1 & 14-Feb & $11: 34$ & 0.000 & 0.000 & 0.000 & 0.000 \\
\hline 32 & 1 & 14-Feb & $11: 24$ & 0.000 & 0.000 & 0.000 & 0.000 \\
\hline 33 & 1 & 14-Feb & $10: 38$ & 0.000 & 0.000 & 0.000 & 0.012 \\
\hline 35 & 1 & 14-Feb & $11: 18$ & 0.000 & 0.000 & 0.000 & 0.000 \\
\hline 37 & 1 & 14-Feb & $11: 11$ & 0.250 & 2.784 & 0.003 & 0.765 \\
\hline
\end{tabular}




\begin{tabular}{|c|c|c|c|c|c|c|c|}
\hline Location & Port & Date & Time & PDCB & $\mathrm{PMCH}$ & o-PDCH & PMCP \\
\hline 38 & 1 & 14-Feb & $11: 09$ & 0.000 & 0.004 & 0.000 & 0.007 \\
\hline 39 & 1 & 14-Feb & $11: 30$ & 0.000 & 0.000 & 0.000 & 0.000 \\
\hline 40 & 1 & 14-Feb & $10: 35$ & 0.007 & 0.020 & 0.012 & 0.076 \\
\hline 41 & 1 & 14-Feb & $10: 46$ & 0.000 & 0.000 & 0.000 & 0.004 \\
\hline 42 & 1 & 14-Feb & $9: 53$ & 0.000 & 0.000 & 0.000 & 0.001 \\
\hline 42 & 2 & 14-Feb & $9: 56$ & 0.000 & 0.100 & 0.026 & 1.068 \\
\hline 42 & 3 & 14-Feb & $9: 57$ & 0.000 & 0.029 & 0.000 & 0.083 \\
\hline 42 & 4 & 14-Feb & $9: 58$ & 0.000 & 0.101 & 0.026 & 1.100 \\
\hline NDBTC & & 14-Feb & $11: 41$ & 0.000 & 0.208 & 2.986 & 4.977 \\
\hline NDPTC & & 14-Feb & $11: 34$ & 0.000 & 0.009 & 0.086 & 0.261 \\
\hline NLIP & & $14-F e b$ & $11: 39$ & 0.000 & 0.224 & 5.980 & 4.979 \\
\hline PSTC & & 14-Feb & $11: 40$ & 0.037 & 0.020 & 0.048 & 0.418 \\
\hline SDBTC & & 14-Feb & $11: 39$ & 0.000 & 0.486 & 0.082 & 23.203 \\
\hline SDPTC & & 14-Feb & $11: 36$ & 0.000 & 0.000 & 0.000 & 0.000 \\
\hline SLIP & & 14-Feb & $11: 32$ & 0.000 & 0.586 & 0.077 & 85.194 \\
\hline 1 & $\mathrm{~S}$ & 16-Feb & $10: 19$ & 0.016 & 0.628 & 0.003 & 1.387 \\
\hline 1 & 1 & 16-Feb & $\wedge$ & 0.000 & 0.739 & 0.012 & 3.590 \\
\hline 1 & 2 & 16-Feb & $\wedge$ & 0.000 & 0.503 & 0.056 & 15.440 \\
\hline 1 & 3 & 16-Feb & $\wedge$ & 0.000 & 0.699 & 0.055 & 12.984 \\
\hline 1 & 4 & 16-Feb & $10: 23$ & 0.049 & 1.727 & 0.004 & 2.294 \\
\hline 2 & S & 16-Feb & $10: 27$ & 0.005 & 0.057 & 0.140 & 0.009 \\
\hline 2 & 1 & 16-Feb & $\wedge$ & 0.087 & 1.032 & 0.002 & 0.110 \\
\hline 2 & 2 & 16-Feb & $\wedge$ & 0.161 & 2.878 & 0.003 & 0.859 \\
\hline 2 & 3 & 16-Feb & $\wedge$ & 0.515 & 3.632 & 0.015 & 4.388 \\
\hline 2 & 4 & 16-Feb & $10: 33$ & 0.186 & 2.605 & 0.040 & 4.194 \\
\hline 3 & S & 16-Feb & $10: 37$ & 0.041 & 0.527 & 0.000 & 0.157 \\
\hline 3 & 1 & 16-Feb & $\wedge$ & 0.140 & 1.668 & 0.000 & 0.452 \\
\hline 3 & 2 & 16-Feb & $\wedge$ & 0.254 & 2.923 & 0.004 & 0.914 \\
\hline 3 & 3 & 16-Feb & $\wedge$ & 0.323 & 3.827 & 0.008 & 1.740 \\
\hline 3 & 4 & 16-Feb & $10: 44$ & 0.110 & 1.520 & 0.035 & 2.835 \\
\hline 4 & 1 & 16-Feb & $10: 48$ & 0.000 & 0.007 & 0.000 & 0.016 \\
\hline 4 & 2 & 16-Feb & $\wedge$ & 0.014 & 0.178 & 0.008 & 0.509 \\
\hline 4 & 3 & 16-Feb & $\wedge$ & 0.068 & 1.007 & 0.055 & 3.469 \\
\hline 4 & 4 & 16-Feb & 10:51 & 0.085 & 1.237 & 0.056 & 3.678 \\
\hline 5 & S & 16-Feb & $10: 52$ & 0.000 & 0.011 & 0.000 & 0.014 \\
\hline 5 & 1 & 16-Feb & $\wedge$ & 0.006 & 0.077 & 0.000 & 0.094 \\
\hline 5 & 2 & 16-Feb & $\wedge$ & 0.015 & 0.213 & 0.000 & 0.106 \\
\hline 5 & 3 & 16-Feb & $\wedge$ & 0.044 & 0.602 & 0.000 & 0.369 \\
\hline 5 & 4 & 16-Feb & $10: 58$ & 0.046 & 0.707 & 0.004 & 0.736 \\
\hline 6 & $S$ & 16-Feb & $11: 38$ & 0.002 & 0.022 & 0.000 & 0.014 \\
\hline 6 & 1 & $16-F e b$ & $\wedge$ & 0.019 & 0.050 & 0.000 & 0.021 \\
\hline 6 & 2 & 16-Feb & $\wedge$ & 0.004 & 0.059 & 0.000 & 0.031 \\
\hline 6 & 3 & 16-Feb & $\wedge$ & 0.004 & 0.040 & 0.000 & 0.045 \\
\hline 6 & 4 & 16-Feb & $11: 43$ & 0.019 & 0.050 & 0.000 & 0.021 \\
\hline 7 & S & $16-\mathrm{Feb}$ & $11: 45$ & 0.000 & 0.000 & 0.000 & 0.001 \\
\hline 7 & 1 & 16-Feb & $\wedge$ & 0.002 & 0.008 & 0.000 & 0.011 \\
\hline 7 & 2 & 16-Feb & $\wedge$ & 0.000 & 0.000 & 0.000 & 0.005 \\
\hline
\end{tabular}




\begin{tabular}{|c|c|c|c|c|c|c|c|}
\hline Location & Port & Date & Time & PDCB & $\mathrm{PMCH}$ & o-PDCH & PMCP \\
\hline 7 & 3 & 16-Feb & $\wedge$ & 0.000 & 0.010 & 0.004 & 0.022 \\
\hline 7 & 4 & 16-Feb & $10: 52$ & 0.000 & 0.009 & 0.000 & 0.035 \\
\hline 8 & 3 & 16-Feb & $11: 46$ & 0.000 & 0.000 & 0.000 & 0.002 \\
\hline 9 & 1 & 16-Feb & $11: 26$ & 0.000 & 0.000 & 0.000 & 0.000 \\
\hline 9 & 2 & 16-Feb & $\wedge$ & 0.000 & 0.000 & 0.000 & 0.002 \\
\hline 9 & 3 & 16-Feb & $\wedge$ & 0.000 & 0.000 & 0.000 & 0.006 \\
\hline 9 & 4 & 16-Feb & $11: 33$ & 0.000 & 0.000 & 0.000 & 0.008 \\
\hline 10 & 1 & 16-Feb & $11: 20$ & 0.000 & 0.000 & 0.000 & 0.003 \\
\hline 10 & 2 & $16-\mathrm{Feb}$ & & 0.000 & 0.000 & 0.000 & 0.000 \\
\hline 10 & 2 & 16-Feb & $\wedge$ & 0.000 & 0.000 & 0.000 & 0.000 \\
\hline 10 & 3 & 16-Feb & $\wedge$ & 0.000 & 0.000 & 0.000 & 0.033 \\
\hline 10 & 4 & 16-Feb & $11: 23$ & 0.000 & 0.045 & 0.005 & 1.316 \\
\hline 11 & 1 & 16-Feb & $11: 14$ & 0.000 & 0.000 & 0.000 & 0.008 \\
\hline 11 & 2 & 16-Feb & $\wedge$ & 0.053 & 0.076 & 0.000 & 0.099 \\
\hline 11 & 3 & 16-Feb & $\wedge$ & 0.151 & 0.343 & 0.103 & 1.058 \\
\hline 11 & 4 & 16-Feb & $11: 18$ & 0.093 & 0.265 & 0.281 & 1.898 \\
\hline 12 & 1 & 16-Feb & 11:07 & 0.081 & 0.157 & 0.000 & 0.086 \\
\hline 12 & 2 & 16-Feb & 11:08 & 0.000 & 0.000 & 0.000 & 0.002 \\
\hline 12 & 3 & 16-Feb & $\wedge$ & 0.218 & 0.707 & 0.012 & 2.897 \\
\hline 12 & 4 & 16-Feb & $11: 10$ & 0.093 & 0.265 & 0.281 & 1.898 \\
\hline 13 & 1 & 16-Feb & 11:01 & 0.000 & 0.000 & 0.000 & 0.000 \\
\hline 13 & 2 & 16-Feb & $\wedge$ & 0.004 & 0.000 & 0.000 & 0.010 \\
\hline 13 & 3 & 16-Feb & $\wedge$ & 0.020 & 0.027 & 0.000 & 0.045 \\
\hline 13 & 4 & 16-Feb & 11:05 & 0.042 & 0.109 & 0.000 & 0.142 \\
\hline 14 & 2 & 16-Feb & 10:54 & 0.000 & 0.000 & 0.000 & 0.000 \\
\hline 14 & 3 & 16-Feb & 10:55 & 0.005 & 0.005 & 0.000 & 0.016 \\
\hline 14 & 4 & 16-Feb & $10: 56$ & 0.016 & 0.017 & 0.000 & 0.069 \\
\hline 15 & 2 & $16-\mathrm{Feb}$ & $10: 47$ & 0.000 & 0.000 & 0.000 & 0.000 \\
\hline 15 & 3 & 16-Feb & $\wedge$ & 0.000 & 0.000 & 0.000 & 0.004 \\
\hline 15 & 4 & 16-Feb & 10:51 & 0.005 & 0.000 & 0.000 & 0.012 \\
\hline 16 & $S$ & 16-Feb & 11:01 & 0.007 & 0.039 & 0.004 & 0.027 \\
\hline 16 & 1 & 16-Feb & $\wedge$ & 0.231 & 1.480 & 0.531 & 1.397 \\
\hline 16 & 2 & 16-Feb & $\wedge$ & 0.000 & 6.930 & 0.389 & 4.732 \\
\hline 16 & 3 & $16-F e b$ & $\wedge$ & 0.863 & 5.722 & 1.772 & 9.851 \\
\hline 16 & 4 & 16-Feb & 11:06 & 1.319 & 12.377 & 0.850 & 6.933 \\
\hline 17 & $S$ & 16-Feb & 11:07 & 0.016 & 0.131 & 0.000 & 0.071 \\
\hline 17 & 1 & 16-Feb & $\wedge$ & 0.193 & 1.283 & 0.007 & 1.652 \\
\hline 17 & 3 & 16-Feb & $\wedge$ & 1.292 & 9.933 & 0.481 & 11.085 \\
\hline 17 & 4 & 16-Feb & $11: 14$ & 1.908 & 19.857 & 0.827 & 7.033 \\
\hline 18 & S & 16-Feb & $11: 15$ & 0.233 & 2.697 & 0.045 & 3.393 \\
\hline 18 & 1 & 16-Feb & $\wedge$ & 0.149 & 1.710 & 0.138 & 8.087 \\
\hline 18 & 2 & 16-Feb & $\wedge$ & 0.119 & 1.191 & 0.246 & 12.547 \\
\hline 18 & 3 & 16-Feb & $\wedge$ & 0.100 & 1.061 & 0.324 & 13.521 \\
\hline 18 & 4 & 16-Feb & $11: 20$ & 0.386 & 3.533 & 0.285 & 13.885 \\
\hline 19 & S & $16-\mathrm{Feb}$ & $11: 22$ & 0.000 & 0.104 & 0.305 & 3.399 \\
\hline 19 & 1 & 16-Feb & $\wedge$ & 0.000 & 0.104 & 0.305 & 3.399 \\
\hline 19 & 2 & 16-Feb & $\wedge$ & 0.000 & 0.172 & 0.302 & 6.157 \\
\hline
\end{tabular}




\begin{tabular}{|c|c|c|c|c|c|c|c|}
\hline Location & Port & Date & Time & PDCB & $\mathrm{PMCH}$ & o-PDCH & PMCP \\
\hline 19 & 3 & $16-\mathrm{Feb}$ & $\wedge$ & 0.272 & 0.271 & 12.208 & 0.544 \\
\hline 19 & 4 & $16-\mathrm{Feb}$ & $11: 26$ & 0.000 & 0.622 & 0.347 & 16.025 \\
\hline 20 & $\mathrm{~S}$ & 16-Feb & $11: 30$ & 0.000 & 0.000 & 0.000 & 0.008 \\
\hline 20 & 1 & 16-Feb & $\wedge$ & 0.000 & 0.047 & 0.400 & 1.572 \\
\hline 20 & 2 & 16-Feb & $\wedge$ & 0.000 & 0.289 & 0.680 & 7.963 \\
\hline 20 & 3 & $16-\mathrm{Feb}$ & $\wedge$ & 0.000 & 0.438 & 0.359 & 13.928 \\
\hline 20 & 4 & 16-Feb & $11: 36$ & 0.097 & 0.562 & 0.525 & 13.079 \\
\hline 21 & S & 16-Feb & 12:01 & 0.000 & 0.009 & 0.018 & 0.101 \\
\hline 21 & 3 & $16-\mathrm{Feb}$ & $12: 13$ & 0.352 & 1.301 & 7.146 & 0.703 \\
\hline 22 & $\mathrm{~S}$ & $16-\mathrm{Feb}$ & $12: 20$ & 0.003 & 0.006 & 0.017 & 0.101 \\
\hline 22 & 1 & 16-Feb & $\wedge$ & 0.000 & 0.114 & 0.936 & 3.280 \\
\hline 22 & 2 & 16-Feb & $\wedge$ & 0.046 & 0.262 & 1.448 & 5.582 \\
\hline 22 & 3 & $16-\mathrm{Feb}$ & $\wedge$ & 0.000 & 0.336 & 1.607 & 6.775 \\
\hline 22 & 4 & 16-Feb & $12: 27$ & 0.402 & 0.739 & 1.411 & 12.173 \\
\hline 23 & 1 & 16-Feb & $12: 30$ & 0.015 & 0.039 & 0.013 & 0.025 \\
\hline 23 & 2 & 16-Feb & $\wedge$ & 0.049 & 0.216 & 1.048 & 4.185 \\
\hline 23 & 3 & $16-\mathrm{Feb}$ & $12: 32$ & 0.065 & 0.338 & 1.313 & 6.423 \\
\hline 23 & 4 & 16-Feb & $12: 33$ & 0.075 & 0.448 & 1.428 & 8.620 \\
\hline 24 & 1 & 16-Feb & $12: 36$ & 0.000 & 0.000 & 0.000 & 0.014 \\
\hline 24 & 2 & 16-Feb & $\wedge$ & 0.035 & 0.187 & 1.038 & 3.834 \\
\hline 24 & 3 & 16-Feb & $\wedge$ & 0.083 & 0.323 & 0.791 & 6.939 \\
\hline 24 & 4 & 16-Feb & $12: 45$ & 1.208 & 0.623 & 23.260 & 2.416 \\
\hline 25 & 1 & 16-Feb & $12: 29$ & 0.000 & 0.000 & 0.000 & 0.031 \\
\hline 25 & 2 & 16-Feb & $\wedge$ & 0.005 & 0.020 & 0.013 & 0.160 \\
\hline 25 & 3 & 16-Feb & $\wedge$ & 0.000 & 0.135 & 0.494 & 5.273 \\
\hline 25 & 4 & 16-Feb & $12: 34$ & 0.000 & 0.496 & 0.691 & 10.209 \\
\hline 26 & 1 & 16-Feb & $12: 00$ & 0.000 & 0.004 & 0.000 & 0.002 \\
\hline 27 & 1 & 16-Feb & $10: 58$ & 0.011 & 0.124 & 0.000 & 0.026 \\
\hline 28 & 1 & 16-Feb & $10: 57$ & 0.035 & 0.457 & 0.000 & 0.217 \\
\hline 29 & 1 & 16-Feb & $10: 56$ & 0.000 & 0.000 & 0.000 & 0.000 \\
\hline 30 & 1 & 16-Feb & $12: 56$ & 0.008 & 0.016 & 0.007 & 0.012 \\
\hline 31 & 1 & 16-Feb & 13:00 & 0.000 & 0.000 & 0.000 & 0.000 \\
\hline 32 & 1 & 16-Feb & $12: 50$ & 0.000 & 0.000 & 0.000 & 0.005 \\
\hline 33 & 1 & 16-Feb & $12: 46$ & 0.000 & 0.000 & 0.000 & 0.003 \\
\hline 35 & 1 & 16-Feb & $12: 08$ & 0.000 & 0.000 & 0.000 & 0.000 \\
\hline 37 & 1 & 16-Feb & $12: 03$ & 0.175 & 2.052 & 0.016 & 0.781 \\
\hline 38 & 1 & 16-Feb & 12:01 & 0.000 & 0.000 & 0.000 & 0.002 \\
\hline 39 & 1 & 16-Feb & 13:02 & 0.000 & 0.000 & 0.000 & 0.003 \\
\hline 40 & 1 & 16-Feb & $12: 47$ & 0.000 & 0.000 & 0.012 & 0.000 \\
\hline 41 & 1 & 16-Feb & $12: 48$ & 0.004 & 0.031 & 0.016 & 0.011 \\
\hline 42 & 2 & 16-Feb & $\wedge$ & 0.000 & 0.000 & 0.000 & 0.000 \\
\hline 42 & 3 & 16-Feb & $\wedge$ & 0.000 & 0.039 & 0.033 & 0.720 \\
\hline 42 & 4 & 16-Feb & $10: 45$ & 0.000 & 0.205 & 0.296 & 4.847 \\
\hline NDBTC & & 16-Feb & 13:05 & 0.102 & 2.195 & 2.722 & 0.204 \\
\hline NDPTC & & 16-Feb & $12: 23$ & 0.006 & 0.094 & 0.177 & 0.012 \\
\hline NLIP & & 16-Feb & $12: 19$ & 0.116 & 2.592 & 3.014 & 0.232 \\
\hline PSTC & & 16-Feb & $12: 53$ & 0.014 & 0.058 & 0.251 & 0.028 \\
\hline
\end{tabular}




\begin{tabular}{|c|c|c|c|c|c|c|c|}
\hline Location & Port & Date & Time & PDCB & $\mathrm{PMCH}$ & o-PDCH & PMCP \\
\hline SDBTC & & 16-Feb & 13:08 & 0.000 & 0.231 & 0.090 & 18.225 \\
\hline SDPTC & & $16-\mathrm{Feb}$ & $12: 26$ & 0.000 & 0.006 & 0.221 & 0.000 \\
\hline SLIP & & 16-Feb & $12: 12$ & 0.000 & 0.307 & 0.091 & 44.661 \\
\hline 1 & $\mathrm{~S}$ & $20-F e b$ & $10: 31$ & 0.000 & 0.305 & 0.004 & 1.008 \\
\hline 1 & 1 & 20-Feb & $\wedge$ & 0.000 & 0.335 & 0.008 & 1.521 \\
\hline 1 & 2 & 20-Feb & $\wedge$ & 0.000 & 0.321 & 0.011 & 1.807 \\
\hline 1 & 3 & 20-Feb & $\wedge$ & 0.000 & 0.350 & 0.009 & 1.528 \\
\hline 1 & 4 & 20-Feb & $\wedge$ & 0.000 & 0.567 & 0.009 & 2.008 \\
\hline 2 & $\mathrm{~S}$ & $20-\mathrm{Feb}$ & $10: 46$ & 0.002 & 0.020 & 0.000 & 0.013 \\
\hline 2 & 1 & 20-Feb & $\wedge$ & 0.045 & 0.618 & 0.000 & 0.165 \\
\hline 2 & 2 & 20-Feb & $\wedge$ & 0.126 & 1.884 & 0.004 & 0.995 \\
\hline 2 & 3 & 20-Feb & $\wedge$ & 0.106 & 1.883 & 0.012 & 2.237 \\
\hline 2 & 4 & 20-Feb & $\wedge$ & 0.095 & 1.429 & 0.019 & 1.930 \\
\hline 3 & $\mathrm{~S}$ & 20-Feb & $10: 53$ & 0.019 & 0.235 & 0.000 & 0.175 \\
\hline 3 & 1 & 20-Feb & $\wedge$ & 0.065 & 0.843 & 0.002 & 0.340 \\
\hline 3 & 2 & 20-Feb & $\wedge$ & 0.085 & 1.057 & 0.003 & 0.463 \\
\hline 3 & 3 & $20-\mathrm{Feb}$ & $\wedge$ & 0.139 & 1.783 & 0.009 & 1.179 \\
\hline 3 & 4 & $20-\mathrm{Feb}$ & $\wedge$ & 0.063 & 0.854 & 0.013 & 1.207 \\
\hline 4 & S & 20-Feb & 11:01 & 0.000 & 0.030 & 0.000 & 0.024 \\
\hline 4 & 1 & 20-Feb & $\wedge$ & 0.000 & 0.000 & 0.000 & 0.004 \\
\hline 4 & 2 & 20-Feb & $\wedge$ & 0.011 & 0.094 & 0.004 & 0.273 \\
\hline 4 & 3 & 20-Feb & $\wedge$ & 0.031 & 0.447 & 0.009 & 0.804 \\
\hline 4 & 4 & 20-Feb & $\wedge$ & 0.037 & 0.556 & 0.012 & 1.041 \\
\hline 5 & S & 20-Feb & $11: 11$ & 0.000 & 0.000 & 0.000 & 0.009 \\
\hline 5 & 1 & 20-Feb & $\wedge$ & 0.002 & 0.035 & 0.000 & 0.054 \\
\hline 5 & 2 & $20-\mathrm{Feb}$ & $\wedge$ & 0.007 & 0.099 & 0.000 & 0.113 \\
\hline 5 & 3 & 20-Feb & $\wedge$ & 0.016 & 0.236 & 0.000 & 0.191 \\
\hline 5 & 4 & 20-Feb & $11: 18$ & 0.010 & 0.119 & 0.000 & 0.120 \\
\hline 6 & $S$ & 20-Feb & $13: 35$ & 0.000 & 0.007 & 0.000 & 0.003 \\
\hline 6 & 1 & 20-Feb & $\wedge$ & 0.002 & 0.026 & 0.000 & 0.012 \\
\hline 6 & 2 & 20-Feb & $\wedge$ & 0.002 & 0.026 & 0.000 & 0.016 \\
\hline 6 & 4 & 20-Feb & $13: 39$ & 0.000 & 0.010 & 0.000 & 0.012 \\
\hline 7 & S & $20-\mathrm{Feb}$ & $11: 47$ & 0.000 & 0.000 & 0.000 & 0.006 \\
\hline 7 & 1 & 20-Feb & $\wedge$ & 0.000 & 0.000 & 0.000 & 0.001 \\
\hline 7 & 2 & 20-Feb & $\wedge$ & 0.002 & 0.000 & 0.000 & 0.003 \\
\hline 7 & 4 & 20-Feb & $11: 59$ & 0.000 & 0.000 & 0.000 & 0.005 \\
\hline 8 & 3 & 20-Feb & $\wedge$ & 0.007 & 0.000 & 0.000 & 0.010 \\
\hline 9 & 1 & 20-Feb & $11: 17$ & 0.000 & 0.000 & 0.000 & 0.003 \\
\hline 9 & 2 & 20-Feb & $\wedge$ & 0.000 & 0.000 & 0.000 & 0.000 \\
\hline 9 & 3 & 20-Feb & $\wedge$ & 0.000 & 0.000 & 0.000 & 0.007 \\
\hline 9 & 4 & $20-\mathrm{Feb}$ & $11: 25$ & 0.000 & 0.000 & 0.000 & 0.003 \\
\hline 10 & 1 & 20-Feb & $11: 10$ & 0.000 & 0.000 & 0.000 & 0.000 \\
\hline 10 & 2 & $20-\mathrm{Feb}$ & $\wedge$ & 0.000 & 0.000 & 0.000 & 0.000 \\
\hline 10 & 3 & $20-\mathrm{Feb}$ & $\wedge$ & 0.000 & 0.000 & 0.000 & 0.001 \\
\hline 10 & 4 & 20-Feb & $11: 15$ & 0.000 & 0.000 & 0.000 & 0.011 \\
\hline 11 & 1 & $20-\mathrm{Feb}$ & 11:03 & 0.000 & 0.000 & 0.000 & 0.000 \\
\hline 11 & 3 & 20-Feb & $\wedge$ & 0.038 & 0.084 & 0.015 & 0.253 \\
\hline
\end{tabular}




\begin{tabular}{|c|c|c|c|c|c|c|c|}
\hline Location & Port & Date & Time & PDCB & $\mathrm{PMCH}$ & o-PDCH & PMCP \\
\hline 11 & 4 & $20-\mathrm{Feb}$ & 11:08 & 0.023 & 0.065 & 0.010 & 0.232 \\
\hline 12 & 1 & $20-\mathrm{Feb}$ & $10: 57$ & 0.026 & 0.050 & 0.000 & 0.066 \\
\hline 12 & 2 & 20-Feb & $\wedge$ & 0.008 & 0.000 & 0.000 & 0.011 \\
\hline 12 & 3 & 20-Feb & $\wedge$ & 0.070 & 0.205 & 0.010 & 0.626 \\
\hline 12 & 4 & 20-Feb & 11:01 & 0.061 & 0.174 & 0.017 & 0.552 \\
\hline 13 & 1 & 20-Feb & $10: 48$ & 0.000 & 0.000 & 0.000 & 0.004 \\
\hline 13 & 2 & 20-Feb & $\wedge$ & 0.000 & 0.000 & 0.000 & 0.004 \\
\hline 13 & 3 & 20-Feb & $\wedge$ & 0.003 & 0.005 & 0.000 & 0.016 \\
\hline 13 & 4 & $20-\mathrm{Feb}$ & $10: 53$ & 0.012 & 0.026 & 0.000 & 0.074 \\
\hline 14 & 2 & 20-Feb & $10: 41$ & 0.000 & 0.000 & 0.000 & 0.005 \\
\hline 14 & 3 & 20-Feb & $\wedge$ & 0.002 & 0.000 & 0.000 & 0.009 \\
\hline 14 & 4 & 20-Feb & $10: 44$ & 0.004 & 0.000 & 0.000 & 0.018 \\
\hline 15 & 2 & 20-Feb & $10: 34$ & 0.000 & 0.000 & 0.000 & 0.000 \\
\hline 15 & 3 & 20-Feb & $\wedge$ & 0.000 & 0.000 & 0.000 & 0.000 \\
\hline 15 & 4 & 20-Feb & $10: 39$ & 0.000 & 0.000 & 0.000 & 0.003 \\
\hline 16 & S & 20-Feb & $11: 43$ & 0.003 & 0.014 & 0.000 & 0.022 \\
\hline 16 & 1 & 20-Feb & $\wedge$ & 0.077 & 0.509 & 0.051 & 0.854 \\
\hline 16 & 2 & 20-Feb & $\wedge$ & 0.488 & 3.131 & 0.221 & 3.646 \\
\hline 16 & 3 & 20-Feb & $\wedge$ & 0.321 & 2.258 & 0.458 & 4.086 \\
\hline 16 & 4 & 20-Feb & $11: 48$ & 0.978 & 10.273 & 0.250 & 4.793 \\
\hline 17 & S & 20-Feb & $11: 51$ & 0.011 & 0.113 & 0.000 & 0.062 \\
\hline 17 & 1 & 20-Feb & $\wedge$ & 0.051 & 0.493 & 0.021 & 1.427 \\
\hline 17 & 3 & 20-Feb & $\wedge$ & 0.283 & 2.269 & 0.211 & 9.390 \\
\hline 17 & 4 & 20-Feb & $11: 57$ & 0.984 & 10.331 & 0.106 & 8.428 \\
\hline 18 & S & 20-Feb & $11: 48$ & 0.108 & 1.542 & 0.040 & 2.268 \\
\hline 18 & 1 & 20-Feb & $\wedge$ & 2.828 & 0.729 & 0.148 & 5.558 \\
\hline 18 & 2 & 20-Feb & $\wedge$ & 0.000 & 0.304 & 0.162 & 7.473 \\
\hline 18 & 3 & 20-Feb & $\wedge$ & 0.000 & 0.226 & 0.143 & 7.618 \\
\hline 18 & 4 & 20-Feb & $11: 53$ & 0.180 & 1.375 & 0.181 & 10.201 \\
\hline 19 & $S$ & 20-Feb & $11: 40$ & 0.000 & 0.008 & 0.000 & 0.016 \\
\hline 19 & 1 & 20-Feb & $\wedge$ & 0.011 & 0.025 & 0.014 & 0.423 \\
\hline 19 & 2 & 20-Feb & $\wedge$ & 0.000 & 0.048 & 0.019 & 0.789 \\
\hline 19 & 3 & 20-Feb & $\wedge$ & 0.000 & 0.163 & 0.025 & 1.650 \\
\hline 19 & 4 & $20-\mathrm{Feb}$ & $11: 46$ & 0.023 & 0.115 & 0.029 & 1.522 \\
\hline 20 & S & 20-Feb & $11: 30$ & 0.000 & 0.000 & 0.000 & 0.007 \\
\hline 20 & 1 & 20-Feb & $\wedge$ & 0.008 & 0.016 & 0.012 & 0.194 \\
\hline 20 & 2 & $20-\mathrm{Feb}$ & $\wedge$ & 0.000 & 0.060 & 0.105 & 1.985 \\
\hline 20 & 3 & 20-Feb & $\wedge$ & 0.000 & 0.168 & 0.059 & 2.642 \\
\hline 20 & 4 & 20-Feb & $11: 36$ & 0.033 & 0.223 & 0.044 & 2.144 \\
\hline 21 & $S$ & 20-Feb & $11: 12$ & 0.000 & 0.000 & 0.000 & 0.016 \\
\hline 21 & 3 & 20-Feb & $\wedge$ & 0.000 & 0.081 & 0.419 & 2.050 \\
\hline 22 & S & 20-Feb & 11:02 & 0.003 & 0.005 & 0.004 & 0.029 \\
\hline 22 & 1 & 20-Feb & $\wedge$ & 0.008 & 0.052 & 0.026 & 0.469 \\
\hline 22 & 2 & 20-Feb & $\wedge$ & 0.000 & 0.055 & 0.093 & 0.867 \\
\hline 22 & 3 & $20-\mathrm{Feb}$ & $\wedge$ & 0.000 & 0.210 & 0.248 & 1.781 \\
\hline 22 & 4 & 20-Feb & 11:08 & 0.151 & 0.315 & 0.615 & 3.564 \\
\hline 23 & 1 & 20-Feb & $10: 57$ & 0.000 & 0.000 & 0.000 & 0.000 \\
\hline
\end{tabular}




\begin{tabular}{|c|c|c|c|c|c|c|c|}
\hline Location & Port & Date & Time & PDCB & $\mathrm{PMCH}$ & o-PDCH & PMCP \\
\hline 23 & 2 & $20-\mathrm{Feb}$ & $\wedge$ & 0.015 & 0.066 & 0.078 & 0.729 \\
\hline 23 & 3 & $20-\mathrm{Feb}$ & $\wedge$ & 0.000 & 0.114 & 0.202 & 1.530 \\
\hline 23 & 4 & 20-Feb & 11:00 & 0.000 & 0.210 & 0.344 & 2.316 \\
\hline 24 & 1 & 20-Feb & $10: 36$ & 0.000 & 0.000 & 0.000 & 0.003 \\
\hline 24 & 2 & 20-Feb & $\wedge$ & 0.010 & 0.045 & 0.073 & 0.668 \\
\hline 24 & 3 & 20-Feb & $\wedge$ & 0.000 & 0.092 & 0.359 & 2.013 \\
\hline 24 & 4 & 20-Feb & $10: 40$ & 0.158 & 0.360 & 0.978 & 6.204 \\
\hline 25 & 1 & 20-Feb & $10: 29$ & 0.000 & 0.000 & 0.000 & 0.003 \\
\hline 25 & 2 & $20-\mathrm{Feb}$ & $\wedge$ & 0.006 & 0.016 & 0.014 & 0.257 \\
\hline 25 & 3 & 20-Feb & $\wedge$ & 0.000 & 0.088 & 0.025 & 1.092 \\
\hline 25 & 4 & 20-Feb & $10: 33$ & 0.000 & 0.269 & 0.064 & 2.768 \\
\hline 26 & 1 & 20-Feb & $11: 21$ & 0.000 & 0.000 & 0.000 & 0.002 \\
\hline 27 & 1 & 20-Feb & $11: 24$ & 0.004 & 0.052 & 0.000 & 0.029 \\
\hline 28 & 1 & 20-Feb & $11: 27$ & 0.015 & 0.202 & 0.000 & 0.179 \\
\hline 29 & 1 & 20-Feb & $11: 29$ & 0.000 & 0.000 & 0.000 & 0.000 \\
\hline 31 & 1 & 20-Feb & $13: 49$ & 0.000 & 0.000 & 0.000 & 0.000 \\
\hline 32 & 1 & 20-Feb & $13: 45$ & 0.000 & 0.000 & 0.000 & 0.000 \\
\hline 33 & 1 & 20-Feb & $10: 51$ & 0.000 & 0.000 & 0.000 & 0.000 \\
\hline 35 & 1 & 20-Feb & 11:31 & 0.000 & 0.000 & 0.000 & 0.000 \\
\hline 36 & 1 & 20-Feb & 11:33 & 0.001 & 0.018 & 0.000 & 0.012 \\
\hline 37 & 1 & 20-Feb & 11:37 & 0.081 & 1.063 & 0.005 & 0.670 \\
\hline 38 & 1 & 20-Feb & 11:40 & 0.000 & 0.000 & 0.000 & 0.002 \\
\hline 39 & 1 & 20-Feb & $13: 47$ & 0.000 & 0.000 & 0.000 & 0.003 \\
\hline 40 & 1 & 20-Feb & $10: 54$ & 0.000 & 0.000 & 0.000 & 0.000 \\
\hline 41 & 1 & 20-Feb & $10: 46$ & 0.000 & 0.000 & 0.000 & 0.003 \\
\hline 42 & 1 & 20-Feb & $10: 30$ & 0.000 & 0.000 & 0.000 & 0.000 \\
\hline 42 & 2 & 20-Feb & $\wedge$ & 0.000 & 0.000 & 0.000 & 0.000 \\
\hline 42 & 3 & 20-Feb & $\wedge$ & 0.000 & 0.014 & 0.000 & 0.016 \\
\hline 42 & 4 & 20-Feb & $10: 34$ & 0.000 & 0.027 & 0.000 & 0.141 \\
\hline NDBTC & & 20-Feb & $13: 54$ & 0.049 & 0.052 & 0.048 & 0.633 \\
\hline NDPTC & & 20-Feb & $14: 12$ & 0.000 & 0.000 & 0.006 & 0.032 \\
\hline NLIP & & 20-Feb & 14:02 & 0.019 & 0.055 & 0.071 & 0.693 \\
\hline PSTC & & 20-Feb & $14: 20$ & 0.022 & 0.010 & 0.012 & 0.094 \\
\hline SDBTC & & $20-\mathrm{Feb}$ & $13: 56$ & 0.054 & 0.124 & 0.013 & 2.029 \\
\hline SDPTC & & 20-Feb & $14: 14$ & 0.000 & 0.000 & 0.000 & 0.025 \\
\hline SLIP & & 20-Feb & $14: 00$ & 0.000 & 0.121 & 0.016 & 1.975 \\
\hline 1 & $\mathrm{~S}$ & 22-Feb & $9: 35$ & 0.000 & 0.223 & 0.000 & 0.568 \\
\hline 1 & 1 & 22-Feb & $\wedge$ & 0.009 & 0.235 & 0.005 & 0.751 \\
\hline 1 & 2 & 22-Feb & $\wedge$ & 0.000 & 0.167 & 0.006 & 0.905 \\
\hline 1 & 3 & 22-Feb & $\wedge$ & 0.000 & 0.220 & 0.007 & 1.007 \\
\hline 1 & 4 & 22-Feb & $\wedge$ & 0.000 & 0.468 & 0.007 & 1.381 \\
\hline 2 & S & 22-Feb & $9: 45$ & 0.000 & 0.009 & 0.000 & 0.005 \\
\hline 2 & 1 & 22-Feb & $\wedge$ & 0.040 & 0.539 & 0.000 & 0.173 \\
\hline 2 & 2 & 22-Feb & $\wedge$ & 0.103 & 1.549 & 0.004 & 0.836 \\
\hline 2 & 3 & 22-Feb & $\wedge$ & 0.115 & 1.635 & 0.010 & 1.562 \\
\hline 2 & 4 & 22-Feb & $\wedge$ & 0.059 & 0.851 & 0.009 & 0.971 \\
\hline 3 & S & 22-Feb & $9: 53$ & 0.016 & 0.206 & 0.000 & 0.176 \\
\hline
\end{tabular}




\begin{tabular}{|c|c|c|c|c|c|c|c|}
\hline Location & Port & Date & Time & PDCB & $\mathrm{PMCH}$ & o-PDCH & PMCP \\
\hline 3 & 1 & $22-\mathrm{Feb}$ & $\wedge$ & 0.047 & 0.611 & 0.000 & 0.308 \\
\hline 3 & 2 & 22-Feb & $\wedge$ & 0.078 & 1.030 & 0.004 & 0.559 \\
\hline 3 & 3 & 22-Feb & $\wedge$ & 0.107 & 1.393 & 0.007 & 0.926 \\
\hline 3 & 4 & 22-Feb & $\wedge$ & 0.034 & 0.483 & 0.007 & 0.595 \\
\hline 4 & 1 & $22-\mathrm{Feb}$ & $\wedge$ & 0.002 & 0.009 & 0.000 & 0.024 \\
\hline 4 & 2 & 22-Feb & $\wedge$ & 0.006 & 0.090 & 0.000 & 0.199 \\
\hline 4 & 3 & 22-Feb & $\wedge$ & 0.018 & 0.289 & 0.006 & 0.529 \\
\hline 4 & 4 & 22-Feb & $\wedge$ & 0.025 & 0.361 & 0.006 & 0.577 \\
\hline 5 & S & 22-Feb & $10: 15$ & 0.000 & 0.008 & 0.000 & 0.004 \\
\hline 5 & 1 & 22-Feb & $\wedge$ & 0.004 & 0.045 & 0.000 & 0.041 \\
\hline 5 & 2 & 22-Feb & $\wedge$ & 0.033 & 0.084 & 0.000 & 0.108 \\
\hline 5 & 3 & 22-Feb & $\wedge$ & 0.014 & 0.168 & 0.000 & 0.131 \\
\hline 5 & 4 & 22-Feb & $10: 20$ & 0.016 & 0.203 & 0.000 & 0.178 \\
\hline 6 & $S$ & 22-Feb & $11: 18$ & 0.000 & 0.000 & 0.000 & 0.002 \\
\hline 6 & 1 & 22-Feb & $\wedge$ & 0.000 & 0.008 & 0.000 & 0.003 \\
\hline 6 & 2 & 22-Feb & $\wedge$ & 0.000 & 0.018 & 0.000 & 0.009 \\
\hline 6 & 3 & $22-F e b$ & $\wedge$ & 0.001 & 0.010 & 0.000 & 0.010 \\
\hline 6 & 4 & 22-Feb & $11: 30$ & 0.002 & 0.011 & 0.000 & 0.009 \\
\hline 7 & S & 22-Feb & $10: 56$ & 0.000 & 0.000 & 0.000 & 0.000 \\
\hline 7 & 1 & 22-Feb & $\wedge$ & 0.000 & 0.000 & 0.000 & 0.000 \\
\hline 7 & 2 & 22-Feb & $\wedge$ & 0.000 & 0.006 & 0.005 & 0.000 \\
\hline 9 & 1 & 22-Feb & $14: 45$ & 0.000 & 0.000 & 0.000 & 0.000 \\
\hline 9 & 2 & 22-Feb & $14: 46$ & 0.000 & 0.000 & 0.000 & 0.000 \\
\hline 9 & 3 & 22-Feb & $14: 48$ & 0.000 & 0.000 & 0.000 & 0.002 \\
\hline 9 & 4 & 22-Feb & $14: 52$ & 0.000 & 0.000 & 0.000 & 0.001 \\
\hline 10 & 1 & 22-Feb & $14: 38$ & 0.000 & 0.000 & 0.000 & 0.000 \\
\hline 10 & 3 & 22-Feb & $\wedge$ & 0.000 & 0.000 & 0.000 & 0.000 \\
\hline 11 & 1 & 22-Feb & $14: 33$ & 0.000 & 0.000 & 0.000 & 0.000 \\
\hline 11 & 2 & 22-Feb & $\wedge$ & 0.010 & 0.018 & 0.003 & 0.033 \\
\hline 11 & 3 & 22-Feb & $\wedge$ & 0.023 & 0.048 & 0.008 & 0.135 \\
\hline 11 & 4 & 22-Feb & $14: 35$ & 0.013 & 0.031 & 0.004 & 0.105 \\
\hline 12 & 1 & 22-Feb & $14: 28$ & 0.013 & 0.024 & 0.000 & 0.037 \\
\hline 12 & 2 & 22-Feb & $\wedge$ & 0.000 & 0.000 & 0.000 & 0.000 \\
\hline 12 & 3 & $22-\mathrm{Feb}$ & $\wedge$ & 0.041 & 0.116 & 0.006 & 0.315 \\
\hline 12 & 4 & 22-Feb & $14: 31$ & 0.036 & 0.101 & 0.009 & 0.296 \\
\hline 13 & 1 & 22-Feb & $14: 20$ & 0.000 & 0.000 & 0.000 & 0.000 \\
\hline 13 & 2 & $22-\mathrm{Feb}$ & $14: 21$ & 0.000 & 0.000 & 0.000 & 0.001 \\
\hline 13 & 4 & 22-Feb & $14: 26$ & 0.007 & 0.012 & 0.000 & 0.036 \\
\hline 14 & 2 & 22-Feb & $9: 48$ & 0.000 & 0.000 & 0.000 & 0.000 \\
\hline 14 & 3 & 22-Feb & $9: 54$ & 0.000 & 0.000 & 0.000 & 0.003 \\
\hline 15 & 2 & 22-Feb & $9: 44$ & 0.000 & 0.000 & 0.000 & 0.000 \\
\hline 15 & 3 & 22-Feb & $\wedge$ & 0.000 & 0.000 & 0.000 & 0.000 \\
\hline 15 & 4 & 22-Feb & $9: 47$ & 0.000 & 0.000 & 0.000 & 0.001 \\
\hline 16 & S & 22-Feb & $11: 16$ & 0.001 & 0.007 & 0.000 & 0.018 \\
\hline 16 & 1 & $22-\mathrm{Feb}$ & $\wedge$ & 0.037 & 0.270 & 0.017 & 0.691 \\
\hline 16 & 2 & 22-Feb & $\wedge$ & 0.250 & 1.771 & 0.108 & 3.348 \\
\hline 16 & 3 & 22-Feb & $\wedge$ & 0.118 & 0.883 & 0.103 & 1.991 \\
\hline
\end{tabular}




\begin{tabular}{|c|c|c|c|c|c|c|c|}
\hline Location & Port & Date & Time & PDCB & $\mathrm{PMCH}$ & o-PDCH & PMCP \\
\hline 16 & 4 & $22-\mathrm{Feb}$ & $11: 21$ & 0.613 & 6.107 & 0.110 & 4.398 \\
\hline 17 & $\mathrm{~S}$ & 22-Feb & 11:04 & 0.008 & 0.077 & 0.000 & 0.061 \\
\hline 17 & 1 & 22-Feb & $\wedge$ & 0.030 & 0.335 & 0.021 & 1.175 \\
\hline 17 & 3 & 22-Feb & $\wedge$ & 0.143 & 1.194 & 0.159 & 7.322 \\
\hline 17 & 4 & 22-Feb & $11: 13$ & 0.561 & 6.315 & 0.113 & 8.092 \\
\hline 18 & $S$ & 22-Feb & $10: 56$ & 0.059 & 0.921 & 0.022 & 1.198 \\
\hline 18 & 1 & 22-Feb & $\wedge$ & 0.032 & 0.427 & 0.051 & 2.101 \\
\hline 18 & 2 & 22-Feb & $\wedge$ & 0.000 & 0.176 & 0.052 & 2.491 \\
\hline 18 & 3 & $22-\mathrm{Feb}$ & $\wedge$ & 0.000 & 0.142 & 0.042 & 2.504 \\
\hline 18 & 4 & 22-Feb & $11: 02$ & 0.060 & 0.604 & 0.064 & 4.355 \\
\hline 19 & S & 22-Feb & $10: 39$ & 0.000 & 0.009 & 0.000 & 0.020 \\
\hline 19 & 1 & 22-Feb & $10: 41$ & 0.000 & 0.025 & 0.004 & 0.202 \\
\hline 19 & 2 & 22-Feb & $\wedge$ & 0.000 & 0.042 & 0.005 & 0.362 \\
\hline 19 & 3 & 22-Feb & $\wedge$ & 0.020 & 0.087 & 0.009 & 0.688 \\
\hline 19 & 4 & 22-Feb & $10: 44$ & 0.016 & 0.150 & 0.019 & 1.235 \\
\hline 20 & S & 22-Feb & $10: 30$ & 0.000 & 0.000 & 0.000 & 0.007 \\
\hline 20 & 1 & 22-Feb & $\wedge$ & 0.005 & 0.006 & 0.000 & 0.038 \\
\hline 20 & 3 & 22-Feb & $\wedge$ & 0.000 & 0.105 & 0.025 & 1.171 \\
\hline 21 & S & 22-Feb & $10: 10$ & 0.001 & 0.000 & 0.000 & 0.008 \\
\hline 21 & 3 & 22-Feb & $\wedge$ & 0.011 & 0.042 & 0.075 & 0.706 \\
\hline 22 & S & 22-Feb & $9: 57$ & 0.000 & 0.000 & 0.000 & 0.008 \\
\hline 22 & 1 & 22-Feb & $\wedge$ & 0.000 & 0.004 & 0.000 & 0.013 \\
\hline 22 & 2 & 22-Feb & $\wedge$ & 0.000 & 0.031 & 0.010 & 0.193 \\
\hline 22 & 4 & 22-Feb & 10:08 & 0.076 & 0.235 & 0.159 & 1.479 \\
\hline 23 & 1 & 22-Feb & $9: 52$ & 0.000 & 0.000 & 0.000 & 0.003 \\
\hline 23 & 2 & 22-Feb & $\wedge$ & 0.009 & 0.042 & 0.011 & 0.201 \\
\hline 23 & 3 & 22-Feb & $\wedge$ & 0.026 & 0.093 & 0.036 & 0.577 \\
\hline 23 & 4 & 22-Feb & $9: 55$ & 0.016 & 0.191 & 0.064 & 0.927 \\
\hline 24 & 1 & 22-Feb & $9: 47$ & 0.026 & 0.000 & 0.000 & 0.035 \\
\hline 24 & 2 & 22-Feb & $\wedge$ & 0.006 & 0.030 & 0.013 & 0.199 \\
\hline 24 & 3 & 22-Feb & $\wedge$ & 0.014 & 0.065 & 0.082 & 0.749 \\
\hline 24 & 4 & 22-Feb & $9: 50$ & 0.060 & 0.166 & 0.420 & 2.599 \\
\hline 25 & 1 & 22-Feb & $9: 42$ & 0.000 & 0.000 & 0.000 & 0.000 \\
\hline 25 & 2 & $22-\mathrm{Feb}$ & $\wedge$ & 0.002 & 0.006 & 0.000 & 0.023 \\
\hline 25 & 3 & 22-Feb & $\wedge$ & 0.005 & 0.035 & 0.007 & 0.174 \\
\hline 25 & 4 & 22-Feb & $9: 45$ & 0.014 & 0.211 & 0.017 & 0.826 \\
\hline 26 & 1 & 22-Feb & $10: 22$ & 0.000 & 0.004 & 0.000 & 0.002 \\
\hline 27 & 1 & 22-Feb & $10: 24$ & 0.005 & 0.051 & 0.000 & 0.026 \\
\hline 28 & 1 & 22-Feb & $10: 26$ & 0.012 & 0.165 & 0.000 & 0.183 \\
\hline 29 & 1 & 22-Feb & $10: 28$ & 0.000 & 0.000 & 0.000 & 0.002 \\
\hline 31 & 1 & 22-Feb & $10: 48$ & 0.000 & 0.000 & 0.000 & 0.002 \\
\hline 32 & 1 & 22-Feb & $10: 53$ & 0.000 & 0.000 & 0.000 & 0.002 \\
\hline 33 & 1 & 22-Feb & $9: 37$ & 0.000 & 0.000 & 0.000 & 0.002 \\
\hline 35 & 1 & 22-Feb & $10: 29$ & 0.000 & 0.000 & 0.000 & 0.000 \\
\hline 36 & 1 & 22-Feb & $10: 31$ & 0.006 & 0.058 & 0.000 & 0.028 \\
\hline 37 & 1 & 22-Feb & $10: 34$ & 0.054 & 0.761 & 0.006 & 0.600 \\
\hline 38 & 1 & 22-Feb & $10: 36$ & 0.002 & 0.000 & 0.000 & 0.005 \\
\hline
\end{tabular}




\begin{tabular}{|c|c|c|c|c|c|c|c|}
\hline Location & Port & Date & Time & PDCB & PMCH & o-PDCH & PMCP \\
\hline 39 & 1 & $22-F e b$ & $10: 50$ & 0.000 & 0.000 & 0.000 & 0.002 \\
\hline 40 & 1 & $22-F e b$ & $9: 38$ & 0.000 & 0.000 & 0.000 & 0.002 \\
\hline 41 & 1 & $22-F e b$ & $9: 31$ & 0.000 & 0.000 & 0.000 & 0.002 \\
\hline 42 & 1 & $22-F e b$ & $9: 39$ & 0.000 & 0.000 & 0.000 & 0.000 \\
\hline 42 & 2 & $22-F e b$ & $\wedge$ & 0.000 & 0.000 & 0.000 & 0.000 \\
\hline 42 & 3 & $22-F e b$ & $\wedge$ & 0.000 & 0.009 & 0.000 & 0.005 \\
\hline 42 & 4 & $22-F e b$ & $9: 43$ & 0.000 & 0.022 & 0.000 & 0.066 \\
\hline NDBTC & & $22-F e b$ & $11: 27$ & 0.000 & 0.034 & 0.000 & 0.204 \\
\hline NDPTC & & $22-F e b$ & $11: 07$ & 0.001 & 0.000 & 0.000 & 0.015 \\
\hline NLIP & & $22-F e b$ & $10: 55$ & 0.010 & 0.039 & 0.017 & 0.222 \\
\hline PSTC & & $22-F e b$ & $11: 14$ & 0.020 & 0.026 & 0.009 & 0.056 \\
\hline SDBTC & & $22-F e b$ & $11: 26$ & 0.000 & 0.000 & 0.000 & 0.034 \\
\hline SDPTC & & $22-F e b$ & $11: 09$ & 0.000 & 0.000 & 0.000 & 0.010 \\
\hline SLIP & & $22-F e b$ & $11: 05$ & 0.000 & 0.080 & 0.000 & 0.741 \\
\hline
\end{tabular}

